\title{
Corrosion Fatigue of Alloys 600 and 690 in Simulated LWR Environments
}

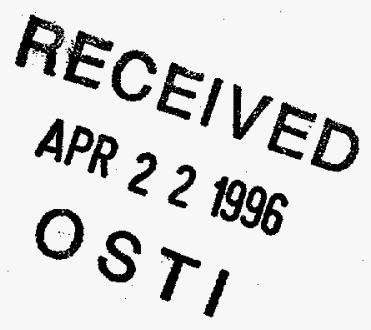

Prepared by

W. E. Ruther, W. K. Soppet, T. F. Kassner

Argonne National Laboratory

Prepared for

U.S. Nuclear Regulatory Commission 


\section{AVAILABILITY NOTICE}

Availability of Reference Materials Cited in NRC Publications

Most documents cited in NRC publications will be available from one of the following sources:

1. The NRC Public Document Room, 2120 L Street. NW., Lower Level, Washington, DC 20555-0001

2. The Superintendent of Documents, U.S. Government Printing Office, P. O. Box 37082, Washington, DC 20402-9328

3. The National Technical Information Service, Springfield, VA 22161-0002

Although the listing that follows represents the majority of documents cited in NRC publications, it is not intended to be exhaustive.

Referenced documents available for inspection and copying for a fee from the NRC Public Document Room include NRC correspondence and internal NRC memoranda; NRC bulletins, circutars, information notices, inspection and investigation notices; licensee event reports; vendor reports and correspondence; Commission papers; and applicant and licensee documents and correspondence.

The following documents in the NUREG series are available for purchase from the Government Printing Office: formal NRC staff and contractor reports, NRC-sponsored conference proceedings, international agreement reports, grantee reports, and NRC booklets and brochures. Also available are regulatory guides, NRC regulations in the Code of Federal Regulations, and Nuclear Regulatory Commission issuances.

Documents available from the National Technical Information Service include NUREG-series reports and technical reports prepared by other Federal agencies and reports prepared by the Atomic Energy Commission, forerunner agency to the Nuclear Regulatory Commission.

Documents available from public and special technical libraries include all open literature items, such as books. journal articles, and transactions. Federal Register notices. Federal and State legislation, and congressional reports can usually be obtained from these libraries.

Documents such as theses, dissertations, foreign reports and translations, and non-NRC conference proceedings are available for purchase from the organization sponsoring the publication cited.

Single copies of NRC draft reports are available free, to the extent of supply, upon written request to the Office of Administration, Distribution and Mall Services Section, U.S. Nuclear Regulatory Commission, Washington, DC 20555-0001.

Coples of industry codes and standards used in a substantive manner in the NRC regulatory process are maintained at the NRC Library. Two White Flint North, 11545 Rockville Pike, Rockville, MD 20852-2738, for use by the public. Codes and standards are usually copyrighted and may be purchased from the originating organization or, if they are American National Standards. from the American National Standards Institute. 1430 Broadway, New York, NY 10018-3308.

\section{DISCLAIMER NOTICE}

This report was prepared as an account of work sponsored by an agency of the United States Government. Neither the United States Government nor any agency thereof, nor any of their employees, makes any warranty, expressed or implied, or assumes any legal liability or responsibility for any third party's use, or the results of such use, of any information, apparatus, product, or process disclosed in this report, or represents that its use by such third party would not infringe privately owned rights. 
NUREG/CR-6383

ANL-95/37

\section{Corrosion Fatigue of Alloys 600 and 690 in Simulated LWR Environments}

Manuscript Completed: March 1996

Date Published: April 1996

Prepared by

W. E. Ruther, W. K. Soppett, T. F. Kassner

Argonne National Laboratory

9700 South Cass Avenue

Argonne, IL 60439

M. McNeil, NRC Project Manager

Prepared for

Division of Engineering Technology

Office of Nuclear Regulatory Research

U.S. Nuclear Regulatory Commission

Washington, DC 20555-0001

NRC Job Code A2212 


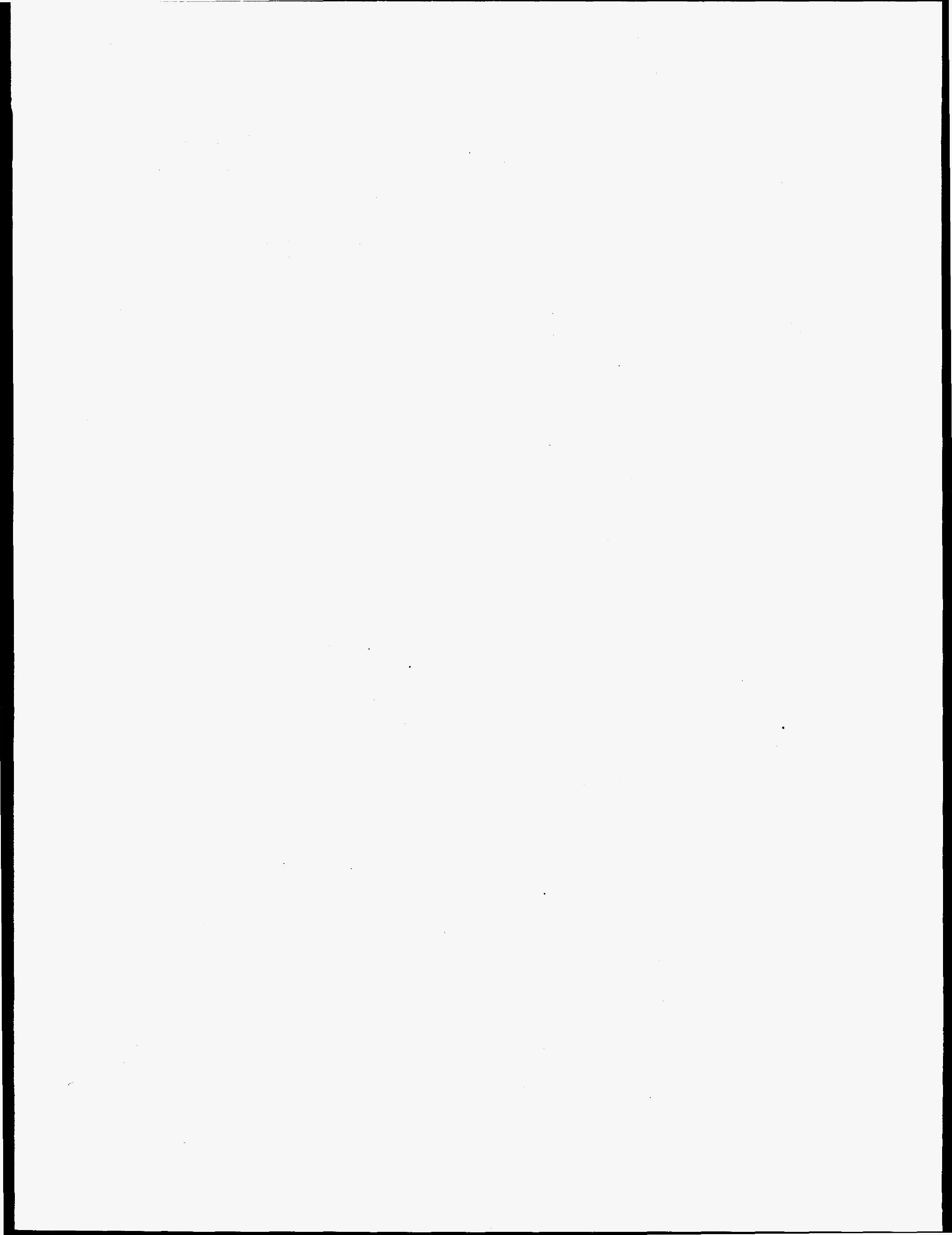




\title{
Corrosion Fatigue of Alloys 600 and 690 in Simulated LWR Environments
}

\author{
by \\ W. E. Ruther, W. K. Soppet, and T. F. Kassner
}

\begin{abstract}
Crack growth data were obtained on fracture-mechanics specimens of Alloys 600 and 690 to investigate environmentally assisted cracking (EAC) in simulated boiling water reactor and pressurized water reactor environments at 289 and $320^{\circ} \mathrm{C}$. Preliminary information was obtained on the effect of temperature, load ratio, stress intensity $(\mathrm{K})$, and the dissolved-oxygen and -hydrogen concentrations of the water on EAC. Specimens of Type 316NG and sensitized Type 304 stainless steel (SS) were included in several of the experiments to assess the behavior of these materials and Alloy 600 under the same water chemistry and loading conditions. The experimental data are compared with predictions from an Argonne National Laboratory (ANL) model for crack growth rates (CGRs) of SSs in water and the ASME Code Section XI correlation for CGRs in air at the $\mathrm{K}_{\max }$ and load-ratio values in the various tests. The data for all of the materials were bounded by ANL model predictions and the ASME Section XI "air line."
\end{abstract}




\section{Contents}

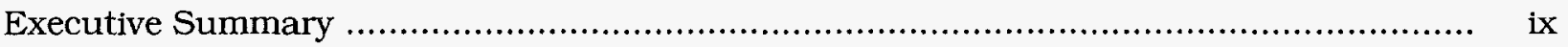

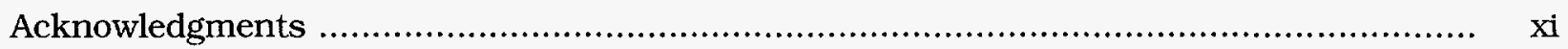

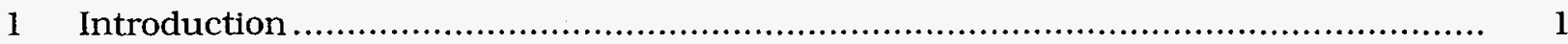

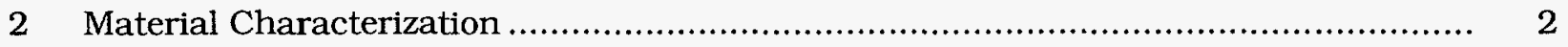

3 Fracture-Mechanics Crack Growth Tests on Alloys 600 and 690 in Simulated LWR

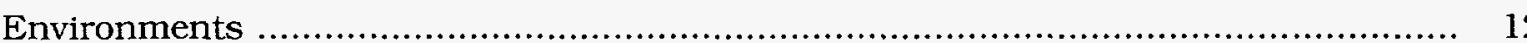

3.1 Comparison of CGRs of Sensitized Type 304 SS and Mill-Annealed Alloy 600 in Oxygenated Water.....

3.2 Comparison of CGRs of Mill-Annealed Alloy 600, Sensitized Type 304 SS, and Type 316NG SS in Oxygenated Water and in Simulated PWR Water

3.3 CGRs of Mill-Annealed Alloy 600 and Thermally Treated Alloy 690 in HP Water at 289 and $320^{\circ} \mathrm{C}$

3.4 CGRs of Mill-Annealed Alloy 600 and Thermally Treated Alloy 690 in Simulated PWR Water at 289 and $320^{\circ} \mathrm{C}$

3.5 Dependence on $\Delta \mathrm{K}$ of CGRs of Mill-Annealed Alloy 600 and Thermally Treated Alloy 690 in HP and Simulated PWR Water at 289 and $320^{\circ} \mathrm{C}$

3.6 Morphology of Crack Path and Surface of Alloy 600 and 690 Specimens ......... 31

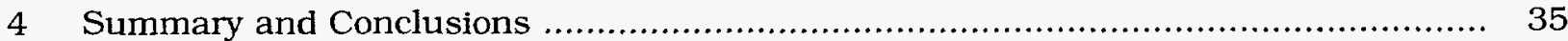

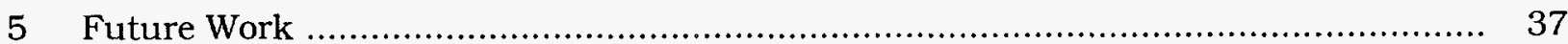

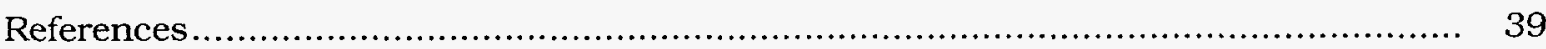




\section{Figures}

1. Dependence of $0.2 \%$ yield stress at 25,290 , and $320^{\circ} \mathrm{C}$ on grain size of annealed Alloy 600 and 690 specimens

2. Relationship between ASTM grain size and average grain diameter.

3. Photomicrographs used to determine grain size of various heats of Alloy 600

4. Photomicrographs used to determine grain size of various heats of Alloy 690

5. Microstructures of Alloy 600, Heat NX8844B-33, that show a uniform distribution of intergranular and intragranular carbides ....

6. Microstructures of Alloy 600, Heat J422, that show semicontinuous intergranular and intragranular carbides

7. Microstructures of Alloy 600, Heat NX8197, that show continuous intergranular and intragranular carbides

8. Microstructures of Alloy 600 , Heat NX8844J-26, that show semicontinuous intergranular and intragranular carbides

9. Microstructures of Alloy 600, Heat NX8844G-3, that show semicontinuous intergranular and intragranular carbides along slip lines

10. Microstructures of Alloy 690 , Heat NX8662HG-33, that show continuous intergranular and relatively few intragranular carbides

11. Microstructures of Alloy 690, Heat NX8625HG-21, that show continuous intergranular and some intragranular carbides

12. Microstructures of Alloy 690 , Heat NX8244HK-1A, that show continuous intergranular but few intragranular carbides

13. Microstructures of Alloy 690, Heat NX8844HK-1B, that show continuous intergranular but few intragranular carbides

14. Solubility of carbon in Alloys 690 and 600 vs. temperature, from Ref. 4

15. Corrosion fatigue data for specimens of Alloy 600 and sensitized Type $304 \mathrm{SS}$ in oxygenated water at $289^{\circ} \mathrm{C}$

16. Dependence of CGR of mill-annealed Alloy 600 specimen on $\mathrm{K}_{\max }$ in

oxygenated water at $289^{\circ} \mathrm{C}$

17. CGRs of Alloy 600 and two sensitized Type 304 SS specimens under identical loading and environmental conditions at $289^{\circ} \mathrm{C}$

18. Corrosion fatigue data for specimens of Alloy 600, Type $316 \mathrm{NG}$ and sensitized Type 304 SS in oxygenated water at $289^{\circ} \mathrm{C}$

19. Corrosion fatigue data for specimens of Alloy 600, Type 316NG and sensitized Type $304 \mathrm{SS}$ in simulated PWR primary water at $289^{\circ} \mathrm{C}$ 
20. Temperature dependence of free energy of formation of $\mathrm{NiO}$ on Alloy 600 in water containing 2 and $60 \mathrm{~cm}^{3} \mathrm{H}_{2} \cdot \mathrm{kg}^{-1} \mathrm{H}_{2} \mathrm{O}$...

21. Calculated thermodynamic stability of $\mathrm{NiO}$ on Alloy 600 as a function of temperature and concentration of dissolved hydrogen in water.

22. Dependence of CGRs of Alloy 600 and 690 specimens in HP water at $320^{\circ} \mathrm{C}$ on DO concentration and ECP of Pt electrode at $289^{\circ} \mathrm{C}$ at load ratios of 0.6 and 0.9

23. Dependence of CGRs of Alloy 600 and 690 specimens in HP water at $289^{\circ} \mathrm{C}$ on DO concentration and ECP of Pt electrode at $289^{\circ} \mathrm{C}$ at load ratios of $0.2,0.6$, and 0.9

24. Dependence of CGRs of Alloy 600 and 690 specimens at 289 and $320^{\circ} \mathrm{C}$ on maximum stress intensity in HP deoxygenated water at load ratios of 0.2 , 0.6 , and 0.9 , and in oxygenated HP water at load ratios of $0.2,0.6$, and 0.9

25. Corrosion fatigue data for Alloy 600 and 690 specimens in HP water at 289 and $320^{\circ} \mathrm{C}$ vs. CGRs for SSs in air, predicted by ASME Code, and CGRs for SSs in water predicted by ANL model, both under same loading conditions as in experiments

26. Dependence of CGRs of Alloy 600 and 690 specimens at 289 and $320^{\circ} \mathrm{C}$ on concentration of dissolved hydrogen in simulated PWR water at load ratio of 0.8

27. Dependence of $\mathrm{CGR}$ at $288^{\circ} \mathrm{C}$ on $\Delta \mathrm{K}$ for $\mathrm{R}$ of $0.2,0.8$, and 0.95 in water containing $1 \mathrm{ppb} \mathrm{DO}$, predicted by ANL model

28. Contribution of air and deoxygenated-water terms in model to crack growth rate at $288^{\circ} \mathrm{C}$ vs. $\Delta \mathrm{K}$ at load ratios of $0.2,0.8,0.9$, and 0.95 .

29. Dependence of CGRs of Alloy 600 and 690 specimens in deoxygenated HP water on $\Delta \mathrm{K}$ at 289 and $320^{\circ} \mathrm{C}$

30. Dependence of CGRs of Alloy 600 and 690 specimens in simulated PWR water on $\triangle \mathrm{K}$ at 289 and $320^{\circ} \mathrm{C}$

31. Dependence of $\Delta \mathrm{K}_{\mathrm{th}}$ for Alloy 600 and 690 specimens in simulated PWR and deoxygenated $\mathrm{HP}$ water on load ratio at 289 and $320^{\circ} \mathrm{C}$

32. Crack path, fracture surface, and fracture morphology of 1TCT specimen of Alloy 600 (No. IN-1) after crack growth experiment in oxygenated HP water and oxygenated water containing chromate, sulfate, 2-butanone-oxime, or ethanolamine at $289^{\circ} \mathrm{C}$.

33. Crack path, fracture surface, and fracture morphology of 1TCT specimen of Alloy 600 (No. IN-2) after crack growth experiment in HP water and simulated PWR water at $289^{\circ} \mathrm{C}$

34. Crack path, fracture surface, and fracture morphology of 1TCT specimen of Alloy 600 (No. 197-07) after crack growth experiment in HP water at 289 and $320^{\circ} \mathrm{C}$ 
35. Crack path, fracture surface, and fracture morphology of ITCT specimen of Alloy 690 (No. HG-07) after crack growth experiment in HP water at 289 and $320^{\circ} \mathrm{C}$.

36. Crack path, fracture surface, and fracture morphology of 1TCT specimen of Alloy 600 (No. 197-09) after crack growth experiment in simulated PWR water at 289 and $320^{\circ} \mathrm{C}$

37. Crack path, fracture surface, and fracture morphology of 1TCT specimen of Alloy 690 (No. HG-09) after crack growth experiment in simulated PWR water at 289 and $320^{\circ} \mathrm{C}$

\section{Tables}

1. Product form and source of Alloys 600 and 690 .

2. Composition of Alloy 600 heats used for corrosion fatigue tests

3. Composition of Alloy 690 heats used for corrosion fatigue tests .

4. Tensile properties of Alloy 600 under various heat treatment conditions................. 4

5. Tensile properties of Alloy 690 under various heat treatment conditions................ 5

6. Crack growth results for Alloy 600 and sensitized Type 304 SS specimens under high-R loading in HP oxygenated water and in oxygenated water that contained chromate, sulfate, 2 -butanone-oxime, or ethanolamine at $289^{\circ} \mathrm{C}$

7. Crack growth results for Alloy 600, Type 316NG, and sensitized Type 304 SS specimens in simulated PWR and HP oxygenated water at $289^{\circ} \mathrm{C}$

8. Crack growth results for Alloy 600 and 690 specimens in HP water at 289 and $320^{\circ} \mathrm{C}$

9. Crack growth results for Alloy 600 and 690 specimens in simulated PWR water at 289 and $320^{\circ} \mathrm{C}$ 


\section{Executive Summary}

Fracture-mechanics crack growth rate (CGR) tests were conducted on compact-tension specimens of mill-annealed Alloy 600 and thermally treated Alloy 690 in oxygenated water and in deaerated water that contained boron, lithium, and low concentrations of dissolved hydrogen at 289 and $320^{\circ} \mathrm{C}$. Specimens of sensitized Type 304 and Type 316NG stainless steel (SS) were included in several experiments to compare the behavior of these materials with that of Alloy 600 under the same water chemistry and loading conditions. The experimental data are compared with predictions from an Argonne National Laboratory (ANL) model for CGRs of SSs in water and the ASME Code Section XI correlation for CGRs in air at the maximum stress intensity $\left(\mathrm{K}_{\max }\right)$ and load-ratio $\mathrm{R}$ values in the various tests. The data for all of the materials were bounded by ANL model predictions and by the ASME "air line."

Comparison of CGRs of Sensitized Type 304 SS and Mill-Annealed Alloy 600 in Oxygenated Water

The effect of water chemistry on CGRs of mill-annealed Alloy 600 and sensitized Type 304 SS was explored at a load ratio of 0.95 . Small amounts of chromate and sulfate $(<200 \mathrm{ppb})$ and two amines (1-5 ppm) in water that contained $\approx 200 \mathrm{ppb}$ dissolved oxygen (DO) produced small but measurable changes in the CGRs of the sensitized Type 304 SS specimens but had virtually no effect on the CGR of the Alloy 600 specimen. The average CGR of the Alloy 600 and sensitized Type 304 SS specimens was $\approx 2.3 \times 10^{-10} \mathrm{~m} \cdot \mathrm{s}^{-1}$ at aload ratio of 0.95 and $\mathrm{K}_{\max }$ of $>30 \mathrm{MPa} \cdot \mathrm{m}^{1 / 2}$ under these water chemistry conditions. This rate is consistent with CGRs of sensitized Type 304 and nonsensitized Type 316NG SS specimens in oxygenated water at $289^{\circ} \mathrm{C}$ under similar loading conditions. The observation that different materials, e.g., Alloy 600 , sensitized Type 304, nonsensitized Type 316NG, and Grade CF-3, CF-8, and CF-8M cast $\mathrm{SS}$, exhibit approximately the same CGR in oxygenated water despite significant differences in material chemistry, microstructure, and mode of crack propagation, suggests that crack propagation is largely controlled by the rate of cathodic reduction of DO with a concomitant anodic dissolution process at the crack tip.

Comparison of CGRs of Mill-Annealed Alloy 600, Sensitized Type 304 SS, and Type 316NG SS in Oxygenated Water and in Simulated PWR Water

Experiments were also performed in simulated pressurized water reactor (PWR) primarysystem water that contained $450 \mathrm{ppm} \mathrm{B}$ and $2.25 \mathrm{ppm} \mathrm{Li}$ (added to the feedwater as $\mathrm{H}_{3} \mathrm{BO}_{3}$ and $\mathrm{LiOH}$ ), 3-58 $\mathrm{cm}^{3} \mathrm{H}_{2} \cdot \mathrm{kg}^{-1} \mathrm{H}_{2} \mathrm{O}, \approx 1 \mathrm{ppb} \mathrm{DO}$, and $750 \mathrm{ppb}$ hydrazine. Hydrazine was added to the feedwater to scavenge residual DO to a very low level. In these experiments, the role of $\mathrm{H}_{3} \mathrm{BO}_{3}$, $\mathrm{LiOH}$, and dissolved hydrogen in crack growth was investigated vis-a-vis high-purity (HP) deoxygenated water. Experimental CGR data for Alloy 600 and Type 304 and 316NG SS specimens in simulated PWR primary-system water were also compared with rates for wrought SSs in air from the ASME Code Section XI correlation and the ANL model that was modified to assess crack growth in low-oxygen environments with no contribution from stress corrosion cracking. With the exception of one data point for an Alloy 600 specimen, the experimental results are bounded by the ANL model prediction and by the air curve for austenitic SSs predicted by the ASME Code. 
CGRs of Mill-Annealed Alloy 600 and Thermally Treated Alloy 690 in HP

Water at 289 and $320^{\circ} \mathrm{C}$

Corrosion-fatigue experiments were conducted on mill-annealed Alloy 600 and millannealed plus thermally treated Alloy 690 specimens in HP water to investigate the effects of temperature, DO, and dissolved hydrogen in water on CGRs of these materials. Initial results were obtained at $289^{\circ} \mathrm{C}$ in water that contained $\approx 6-8 \mathrm{ppm}$ and $<5 \mathrm{ppb} \mathrm{DO}$, load ratios of 0.2 , 0.6 , and 0.9 , and $\mathrm{K}_{\max }$ of $31-33 \mathrm{MPa} \cdot \mathrm{m}^{1 / 2}$. Crack growth behavior of the two materials is quite similar under the conditions in these experiments. In water that contained $<5 \mathrm{ppb} \mathrm{DO}$, CGRs at 289 and $320^{\circ} \mathrm{C}$ were similar. At a load ratio of 0.6 , CGRs are not dependent on DO, which is indicative of a strong contribution of cyclic loading to the rates. At a higher load ratio of 0.9 , CGRs decreased as DO concentration decreased at 289 and $320^{\circ} \mathrm{C}$. In all cases, CGRs of both materials were near or below the "air" curve for austenitic SSs.

Several tests were conducted at $320^{\circ} \mathrm{C}$ in $\mathrm{HP}$ water that contained $<5 \mathrm{ppb}$ DO and $\approx 0,2.2$ and $53 \mathrm{~cm}^{3} \cdot \mathrm{kg}^{-1}$ dissolved hydrogen. At a load ratio of 0.9 , CGRs of both specimens were low $\left(0.5-1.3 \times 10^{-11} \mathrm{~m} \cdot \mathrm{s}^{-1}\right)$ and dissolved hydrogen over the range of $\approx 2-53 \mathrm{~cm}^{3} \mathrm{H}_{2} \cdot \mathrm{kg}^{-1} \mathrm{H}_{2} \mathrm{O}$ did not influence the rates at a $\mathrm{K}_{\max }$ of $\approx 34 \mathrm{MPa} \cdot \mathrm{m}^{1 / 2}$. In contrast to results at lower load ratios (i.e., $\leq 0.6$ ), CGRs of Alloy 600 were greater than those of Alloy 690 by factors of $\approx 2-5$.

CGRs of Mill-Annealed Alloy 600 and Thermally Treated Alloy 690 in Simulated PWR Water at 289 and $320^{\circ} \mathrm{C}$

The influence of dissolved hydrogen in simulated PWR water on CGRs of Alloy 600 and 690 specimens at 289 and $320^{\circ} \mathrm{C}$ was determined in another series of experiments. The water contained $450 \mathrm{ppm} \mathrm{B,} 2.25 \mathrm{ppm} \mathrm{Li},<2 \mathrm{ppb} \mathrm{DO}$, and $\approx 3-58 \mathrm{~cm}^{3} \mathrm{H}_{2} \cdot \mathrm{kg}^{-1} \mathrm{H}_{2} \mathrm{O}$. Tests were conducted at a load ratio of 0.8 and $\mathrm{K}_{\max }$ in the range of $\approx 30-41 \mathrm{MPa} \cdot \mathrm{m}^{1 / 2}$. CGRs decreased slightly as dissolved hydrogen concentration was increased from 3 to $58 \mathrm{~cm}^{3} \cdot \mathrm{kg}^{-1}$. At both temperatures, and under these water chemistry and loading conditions, the CGR of Alloy 690 was higher by a factor of $\approx 3$ than the CGR of Alloy 600 .

CGRs decrease significantly as load ratio increases in both HP and simulated PWR water environments. At load ratios $\leq 0.8$, it appears that CGRs of the Alloy 690 specimens are slightly higher than those of Alloy 600; however, at a load ratio of 0.9 the CGRs of the alloys are similar. Crack growth experiments will be conducted at higher load ratios, including constant load $(\mathrm{R}=1.0)$, to determine whether Alloy 690 exhibits lower rates than Alloy 600 at higher $\mathrm{R}$ values. 


\section{Acknowledgments}

The authors thank W. F. Burke, D. J. Gavenda, and D. R. Perkins for their contributions to the experimental effort, and W. J. Shack for helpful comments. The authors are grateful to J. R. Crum of INCO Alloys International, Huntington, WV; A. Mcllree of the Electric Power Research Institute (EPRI), Palo Alto, CA; and C. M. Blanchard of the EPRI Nondestructive Evaluation Center, Charlotte, $\mathrm{NC}$, for supplying heats of material for this investigation. This work is sponsored by the Office of Nuclear Regulatory Research, U.S. Nuclear Regulatory Commission, under FIN Number A2212; Program Manager: Dr. M. B. McNeil. 


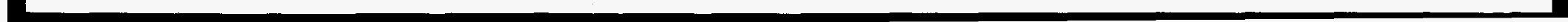




\section{Introduction}

The objective of this work is to evaluate and compare the resistance of Alloys 600 and 690 to environmentally assisted cracking (EAC) in simulated light water reactor (LWR) coolant environments. High-nickel alloys have experienced general corrosion (tube wall thinning), localized intergranular attack (IGA), and stress corrosion cracking (SCC) in LWRs. Secondaryside IGA ${ }^{*}$ and axial and circumferential SCC $^{* *}$ have occurred in Alloy 600 tubes at tube support plates in many steam generators. Primary-water stress corrosion cracking (PWSCC) of Alloy 600 steam generator tubes in pressurized water reactors (PWRs) at roll transitions and U-bends and in tube plugs ${ }^{* * *}$ is a widespread problem that has been studied intensively. Cracking has also occurred in Alloy 600 and other high-nickel alloys (e.g., Inconel-82 and -182 and Alloy X750) that are used in applications such as (a) instrument nozzles and heater thermal sleeves in the pressurizer ${ }^{\dagger}$ and penetrations for control-rod drive mechanisms in reactor vessel closure heads in the primary system of PWRs ${ }^{\dagger \dagger}$ and (b) in dissimilar-metal welds between SS piping and low-alloy steel nozzles, in jet pump hold-down beams, $\dagger^{\dagger \dagger}$ and in shroud-support-access-hole covers $\$$ in boiling water reactors (BWRs). Alloy 600, in general, undergoes different thermomechanical processing for applications other than those used for steam generator tubes. Because environmental degradation of the alloys in many cases is very sensitive to processing, further evaluation of even SCC is needed. In addition, experience strongly suggests that materials that are susceptible to SCC are also susceptible to environmental degradation of fatigue life and fatigue-crack growth properties.

In this investigation, we have obtained preliminary information on the effect of temperature, load ratio R, and stress intensity (K) on EAC of Alloys 600 and 690 in simulated BWR and PWR water. Crack growth rates (CGRs) of these materials have been compared with those of Type $316 \mathrm{NG}$ and sensitized Type 304 SS under conditions where EAC occurs in all of the materials.

*USNRC Information Notice No. 91-67, "Problems with the Reliable Detection of Intergranular Attack (IGA) of Steam Generator Tubing," October 1991.

** USNRC Information Notice No. 90-49, "Stress Corrosion Cracking in PWR Steam Generator Tubes," August 1990; Notice No. 91-43, "Recent Incidents Involving Rapid Increases in Primary-to-Secondary Leak Rate," July 1991; Notice No. 92-80, "Operation with Steam Generator Tubes Seriously Degraded," December 1992; Notice No. 94-05, "Potential Failure of Steam Generator Tubes with Kinetically Welded Sleeves," January 1994.

*** USNRC Information Notice No. 89-33, "Potential Failure of Westinghouse Steam Generator Tube Mechanical Plugs," March 1989; Notice No. 89-65, "Potential for Stress Corrosion Cracking in Steam Generator Tube Plugs Supplied by Babcock and Wilcox," September 1989; Notice No. 94-87, "Unanticipated Crack in a Particular Heat of Alloy 600 Used for Westinghouse Mechanical Plugs for Steam Generator Tubes," December 1994.

†USNRC Information Notice No. 90-10, "Primary Water Stress Corrosion Cracking (PWSCC) of Inconel 600," February 1990.

$\dagger \dagger$ INPO Document SER 20-93 "Intergranular Stress Corrosion Cracking of Control Rod Drive Mechanism Penetrations," September 1993.

$\dagger^{\dagger}$ USNRC Information Notice No. 93-101, "Jet Pump Hold-Down Beam Failure," December 1993.

\$USNRC Information Notice No. 92-57, "Radial Cracking of Shroud Support Access Hole Cover Welds," August 1992. 


\section{Material Characterization}

The various heats of Alloys 600 and 690 that were obtained for corrosion-fatigue testing were characterized. The heat identification numbers, product form, and source of materials for fabrication of $1 \mathrm{~T}$ compact tension (1TCT) specimens are given in Table 1.

Table 1. Product form and source of Alloys 600 and 690

\begin{tabular}{|c|c|c|c|c|}
\hline Material & Heat No. & Material Condition & Product Form & Source \\
\hline 600 & NX8844B-33 & Annealed $872^{\circ} \mathrm{C} / 1 \mathrm{~h}$ & 1.0-in.-thick plate & EPRIa \\
\hline 600 & $\mathrm{~J} 422$ & Mill Annealed & 1T-CT specimens & Metal Samples Co. \\
\hline 600 & NX8197 & Mill Annealed & 1.0-in.-thick plate & A. M. Castle \& Co. \\
\hline 600 & NX8844J-26 & Annealed $1038^{\circ} \mathrm{C} / 1 \mathrm{~h}$ & 1.0-in.-thick plate & EPRI \\
\hline 600 & NX8844G-3 & $\begin{array}{l}\text { Hot Worked } 982^{\circ} \mathrm{C} \text {, } \\
20 \% \text { Reduction }\end{array}$ & 1.0-in.-thick plate & EPRI \\
\hline 690 & NX8662HG-33 & Annealed $+715^{\circ} \mathrm{C} / 5 \mathrm{~h}$ & 1.34-in.-thick plate & INCO Alloys Int1., Inc. \\
\hline 690 & NX8625HG-21 & Annealed $+715^{\circ} \mathrm{C} / 5 \mathrm{~h}$ & 1.34-in.-thick plate & EPRI \\
\hline 690 & NX8244HK-1A & Annealed $982^{\circ} \mathrm{C} / 1 \mathrm{~h}$ & 1.0-in.-thick plate & EPRI \\
\hline 690 & NX8244HK-1B & Annealed $1093^{\circ} \mathrm{C} / 1 \mathrm{~h}$ & 1.0-in.-thick plate & EPRI \\
\hline
\end{tabular}

aNumerous heats of Alloys 600 and 690 were fabricated by INCO Alloys International, Inc., Huntington, WV. for the Electric Power Research Institute (EPRI), Palo Alto, CA, which provided materials for this study.

The composition of the materials is given in Tables 2 and 3 . The tensile properties of cylindrical specimens in air at 25,290 , and $320^{\circ} \mathrm{C}$ and at a strain rate of $1.0 \times 10^{-4} \mathrm{~s}^{-1}$ were determined in accordance with ASTM Standard E8. Vickers hardness was measured at room temperature, and average grain size of the various heats of Alloys 600 and 690 was determined by following the procedure in ASTM Standard E112. The results for Alloys 600 and 690 are given in Tables 4 and 5, respectively. Properties obtained from certified material test reports (CMTRs) supplied by the vendors or documentation obtained from the EPRI are also included in Tables 4 and 5. Data for annealed specimens tend to follow a Petch relationship, i.e., $\sigma_{\mathrm{y}}=\sigma_{\mathrm{i}}+\mathrm{k} \cdot \mathrm{d}^{-1 / 2}$, where $\sigma_{\mathrm{y}}$ is the yield stress; $\mathrm{d}$, the grain diameter; $\mathrm{k}$, an emperical constant; and $\sigma_{i}$, the "friction" stress, which is a measure of intrinsic resistance of the material to dislocation motion. The dependence of the yield stress of annealed Alloy 600 (Heat NX8844) and 690 (Heat NX8244HK) specimens on average grain size at 25, 290, and $320^{\circ} \mathrm{C}$ is shown in Fig. 1. The relationship between ASTM grain size and average grain diameter is shown in Fig. 2. Photomicrographs that were used to determine the grain size of the various heats of Alloys 600 and 690 are shown in Figs. 3 and 4, respectively.

A small section of each material was used to prepare metallographic specimens to qualitatively determine the degree of grain boundary carbide coverage by optical metallography. Specimens were polished to a $0.25-\mu \mathrm{m}$ diamond finish with Struers DP-Spray, and a Vickers hardness indentation was made to provide a reference point for subsequent examination to reveal the carbide distribution and grain boundaries after two chemical etching methods. The specimens were electroetched in a $10 \% \mathrm{H}_{3} \mathrm{PO}_{4}$ solution at $\approx 10 \mathrm{~V}$ for $\approx 25 \mathrm{~s}$, rinsed in ethanol, and air dried. Photomicrographs obtained at 500X magnification reveal 
Table 2. Composition of Alloy 600 heats used for corrosion fatigue tests

\begin{tabular}{|c|c|c|c|c|c|c|c|c|c|c|c|c|c|c|c|c|c|c|}
\hline \multirow{2}{*}{ Material } & \multirow{2}{*}{$\begin{array}{c}\text { Heat } \\
\text { No. }\end{array}$} & \multirow[b]{2}{*}{ Analysis } & \multicolumn{16}{|c|}{ Composition (wt.\%) } \\
\hline & & & $\mathrm{Cr}$ & Mo & $\mathrm{Ni}$ & $\mathrm{Fe}$ & $\mathrm{Mn}$ & $\mathrm{Si}$ & $\mathrm{C}$ & $\mathrm{N}$ & $\mathrm{P}$ & $\mathrm{S}$ & $\mathrm{B}$ & $\mathrm{Cu}$ & $\mathrm{Ti}$ & $\mathrm{Al}$ & Co & $\mathrm{Nb}+\mathrm{Ta}$ \\
\hline \multirow[t]{2}{*}{ Alloy 600} & $\mathrm{~J} 422$ & Vendor & 15.36 & - & 75.72 & 7.51 & 0.21 & 0.32 & 0.080 & - & 0.008 & $<0.001$ & - & 0.15 & 0.24 & 0.28 & 0.05 & 0.07 \\
\hline & & ANL & 15.37 & 0.23 & 76.36 & 7.27 & 0.20 & 0.32 & 0.080 & 0.0145 & 0.016 & 0.004 & 0.002 & 0.15 & 0.16 & 0.27 & 0.05 & 0.06 \\
\hline \multirow[t]{2}{*}{ Alloy 600} & NX8197 & Vendor & 15.88 & - & 75.05 & 7.76 & 0.22 & 0.23 & 0.080 & - & 0.006 & 0.002 & - & 0.12 & 0.27 & 0.26 & 0.05 & 0.07 \\
\hline & & ANL & 15.43 & 0.58 & 73.82 & 9.20 & 0.20 & 0.27 & 0.080 & 0.0099 & 0.016 & 0.002 & 0.002 & 0.11 & 0.18 & 0.24 & 0.06 & 0.05 \\
\hline \multirow[t]{4}{*}{ Alloy 600} & NX8844 & Vendor & 14.97 & 0.15 & 75.21 & 8.26 & 0.26 & 0.24 & 0.069 & 0.01 & 0.009 & $<0.001$ & 0.004 & 0.22 & 0.29 & 0.27 & 0.04 & - \\
\hline & $\mathrm{NX} 8844 \mathrm{~B}-33$ & ANL & 15.03 & 0.17 & 75.16 & 7.93 & 0.24 & 0.27 & 0.080 & 0.0146 & 0.019 & 0.001 & 0.003 & 0.22 & 0.21 & 0.28 & 0.04 & 0.04 \\
\hline & NX8844J-26 & ANL & 15.00 & 0.16 & 74.94 & 8.14 & 0.23 & 0.32 & 0.060 & 0.0155 & 0.014 & 0.002 & 0.004 & 0.22 & 0.24 & 0.24 & 0.03 & 0.03 \\
\hline & $\mathrm{NX} 8844 \mathrm{G}-3$ & ANL & 15.14 & 0.16 & 74.78 & 8.28 & 0.23 & 0.35 & 0.070 & 0.0145 & 0.015 & 0.002 & 0.005 & 0.22 & 0.25 & 0.25 & 0.04 & 0.04 \\
\hline
\end{tabular}

Table 3. Composition of Alloy 690 heats used for corrosion fatigue tests

\begin{tabular}{|c|c|c|c|c|c|c|c|c|c|c|c|c|c|c|c|c|c|c|}
\hline \multirow[t]{2}{*}{ Material } & \multirow{2}{*}{$\begin{array}{c}\text { Heat } \\
\text { No. }\end{array}$} & \multirow[b]{2}{*}{ Analysis } & \multicolumn{16}{|c|}{ Composition (wt.\%) } \\
\hline & & & $\mathrm{Cr}$ & Mo & Ni & $\mathrm{Fe}$ & $\mathrm{Mn}$ & Si & $\mathrm{C}$ & $\mathrm{N}$ & $\mathbf{P}$ & $\mathrm{s}$ & $\mathrm{B}$ & $\mathrm{Cu}$ & $\mathrm{Ti}$ & $\mathrm{Al}$ & $\mathrm{Co}$ & $\mathrm{Nb}+\mathrm{Ta}$ \\
\hline \multirow[t]{2}{*}{ Alloy 690} & NX8662HG-33 & Vendor & 30.25 & - & 59.31 & 9.54 & 0.10 & 0.16 & 0.030 & 0.050 & 0.008 & $<0.001$ & 0.004 & 0.04 & 0.28 & 0.33 & 0.022 & - \\
\hline & & ANL & 30.46 & 0.04 & 58.88 & 9.22 & 0.11 & 0.16 & 0.030 & 0.047 & 0.017 & 0.001 & 0.003 & 0.05 & 0.25 & 0.32 & 0.020 & 0.01 \\
\hline \multirow[t]{2}{*}{ Alloy 690} & NX8625HG-21 & Vendor & 30.28 & - & 58.56 & 10.00 & 0.11 & 0.26 & 0.027 & 0.030 & 0.009 & $<0.001$ & 0.004 & 0.06 & 0.32 & 0.44 & 0.036 & - \\
\hline & & ANL & 30.64 & 0.02 & 58.10 & 9.84 & 0.12 & 0.32 & 0.030 & 0.029 & 0.009 & 0.002 & 0.004 & 0.01 & 0.28 & 0.39 & 0.030 & $<0.01$ \\
\hline \multirow[t]{3}{*}{ Alloy 690} & NX8244HK & Vendor & 30.03 & - & 59.85 & 9.20 & 0.20 & 0.14 & 0.018 & 0.01 & 0.004 & $<0.001$ & 0.002 & $<0.01$ & 0.20 & 0.36 & 0.003 & - \\
\hline & NX8244HK-1A & ANL & 30.66 & $<0.01$ & 59.09 & 9.22 & 0.20 & 0.18 & 0.024 & 0.010 & 0.004 & 0.002 & 0.002 & $<0.01$ & 0.20 & 0.31 & $<0.01$ & $<0.01$ \\
\hline & NX8244HK-1B & ANL & 30.64 & $<0.01$ & 59.20 & 9.19 & 0.21 & 0.18 & 0.023 & 0.011 & 0.005 & 0.002 & 0.002 & $<0.01$ & 0.19 & 0.32 & $<0.01$ & $<0.01$ \\
\hline
\end{tabular}


Table 4. Tensile properties of Alloy 600 under various heat treatment conditions

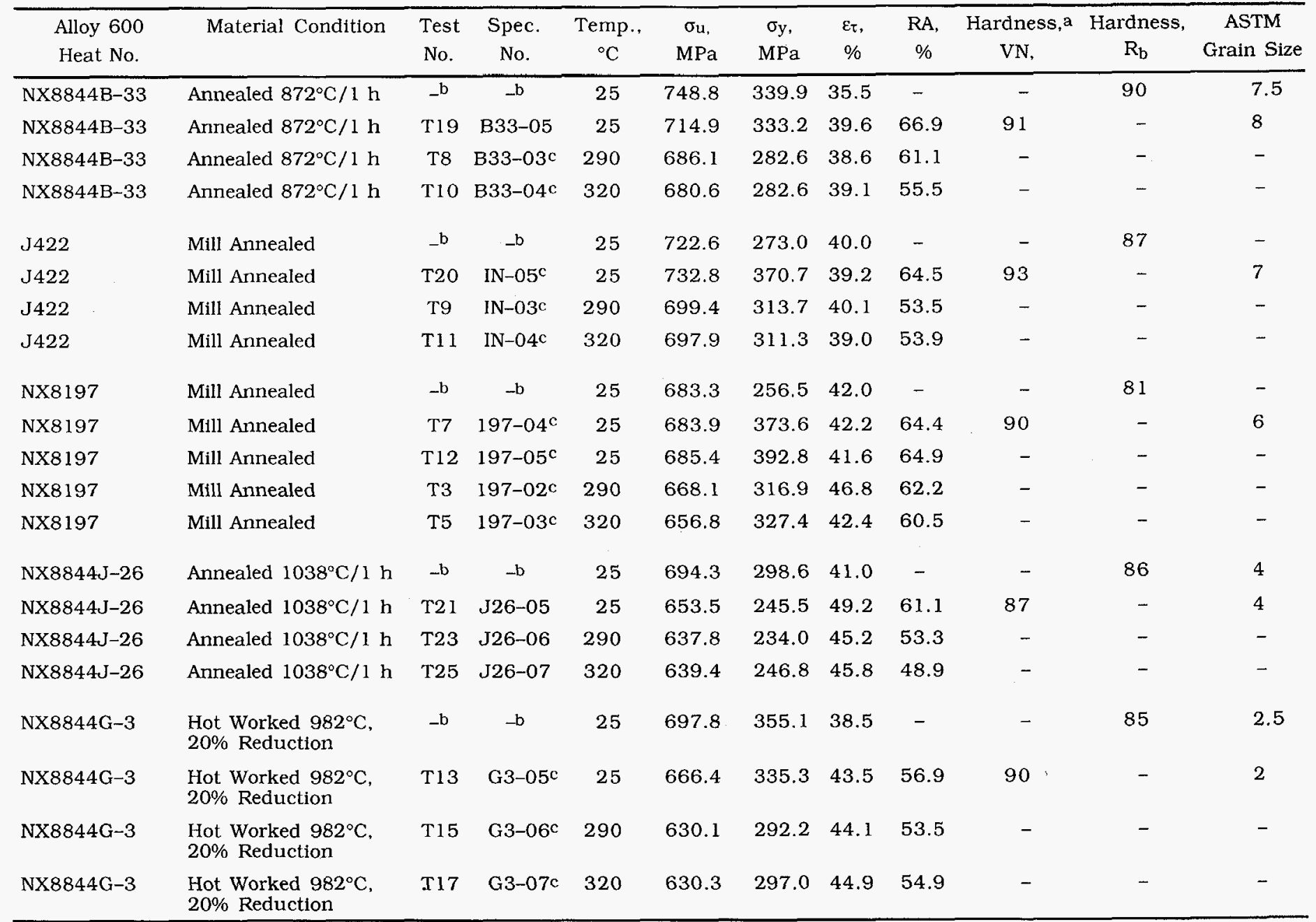

Vickers hardness at room temperature, $500 \mathrm{gf}, 15 \mathrm{~s}$

$\mathrm{b}_{\text {Results from vendor (EPRI document or CMTRs). }}$

Tensile tests conducted in air at a strain rate of $1.0 \times 10^{-4} \mathrm{~s}^{-1}$. 
Table 5. Tensile properties of Alloy 690 under various heat treatment conditions

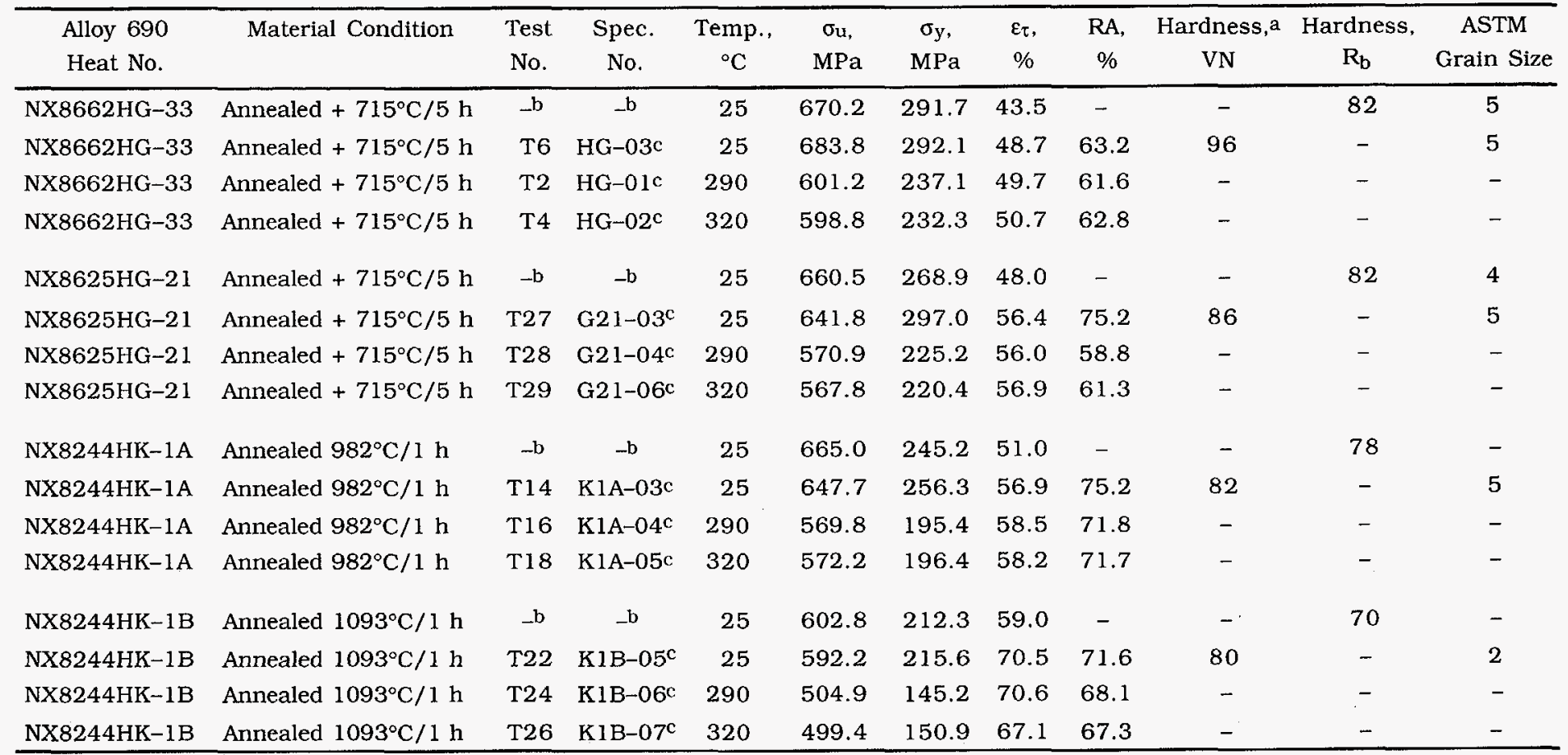

aVickers hardness at room temperature, $500 \mathrm{gf}, 15 \mathrm{~s}$

$b_{\text {Results from vendor (EPRI document). }}$

CTensile tests conducted in air at a strain rate of $1.0 \times 10^{-4} \mathrm{~s}^{-1}$. 

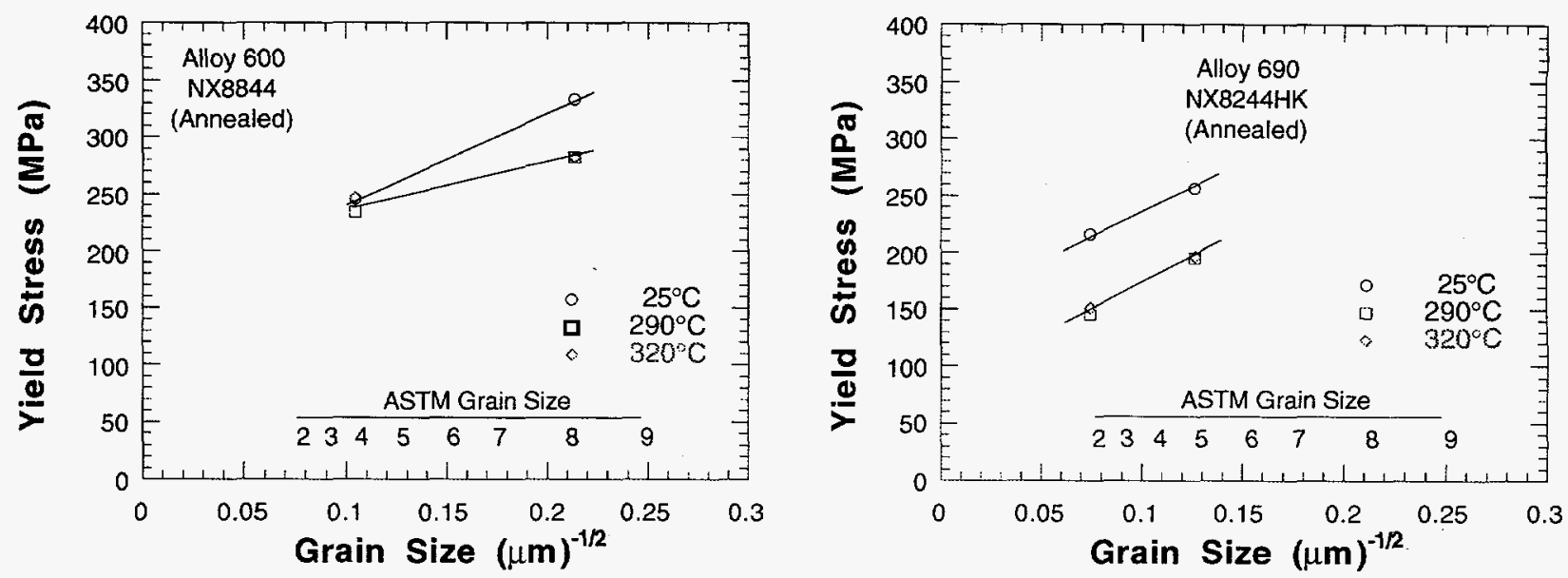

Figure 1. Dependence of $0.2 \%$ yield stress at 25,290 , and $320^{\circ} \mathrm{C}$ on grain size of annealed Alloy 600 and 690 specimens

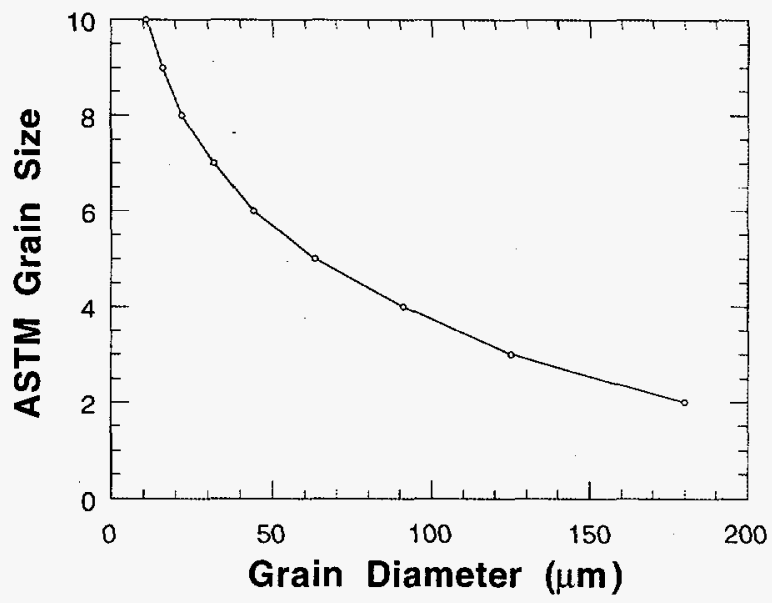

Figure 2.

Relationship between ASTM grain size and average grain diameter

that carbides were the predominant phase present in the specimens. The specimens were repolished with 1.0 and $0.25-\mu \mathrm{m}$ diamond spray, electroetched in a $5 \%$ nital solution $(5 \mathrm{~mL}$ of $\mathrm{HNO}_{3}$ in $100 \mathrm{~mL}$ ethanol) at $\approx 10 \mathrm{~V}$ for $\approx 35 \mathrm{~s}$, rinsed in ethanol, and air dried. The same locations on the specimens were photographed once again at a magnification of 500X, with the aid of the hardness indentation, to better reveal grain boundaries and obtain a qualitative estimate of the extent of carbide precipitation thereon.

Photomicrographs of the five heats of Alloy $600(\approx 0.06$ wt.\% carbon $)$ in Figs. $5-9$ indicate either semicontinuous or continuous carbide precipitation at the grain boundaries and a significant amount of intragranular carbide. Photomicrographs of the four heats of Alloy 690 $(\approx 0.03$ wt.\% carbon) in Figs. $10-13$ reveal continuous precipitation of carbides at the grain boundaries, with relatively few intragranular carbides. The precipitate phases present in Alloys 600 and 690 are $\mathrm{Cr}$-rich $\mathrm{M}_{7} \mathrm{C}_{3}$ and $\mathrm{M}_{23} \mathrm{C}_{6}$ carbides and Ti(C,N) carbonitrides. ${ }^{1-3}$ In general, the microstructures are consistent with the thermomechanical processing histories and carbon concentrations vis-a -vis the solubility of carbon in the materials (Fig. 14). 4 Namely, according to these carbon solubility data, none of the materials was annealed at a temperature high enough to dissolve all of the carbon in the grain matrix (Alloy $690,>1200^{\circ} \mathrm{C}$ and Alloy $600,>1080^{\circ} \mathrm{C}$ ); consequently, carbides are present on grain boundaries as well as within the grains, in particular, Alloy 600 , which contains $\approx 0.06$ wt. $\%$ carbon. 


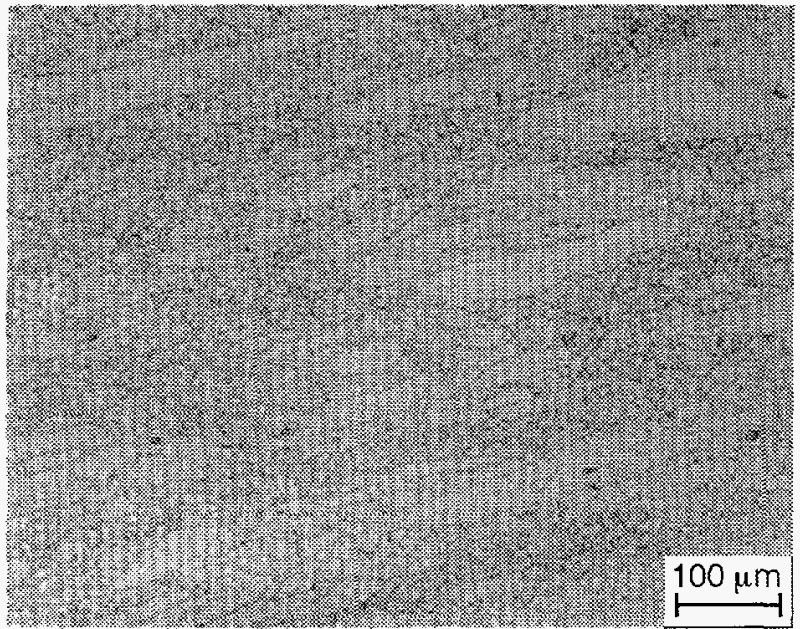

(a) Heat NX8844B-33, annealed at $872^{\circ} \mathrm{C}$ for $1 \mathrm{~h}$, ASTM grain size 8

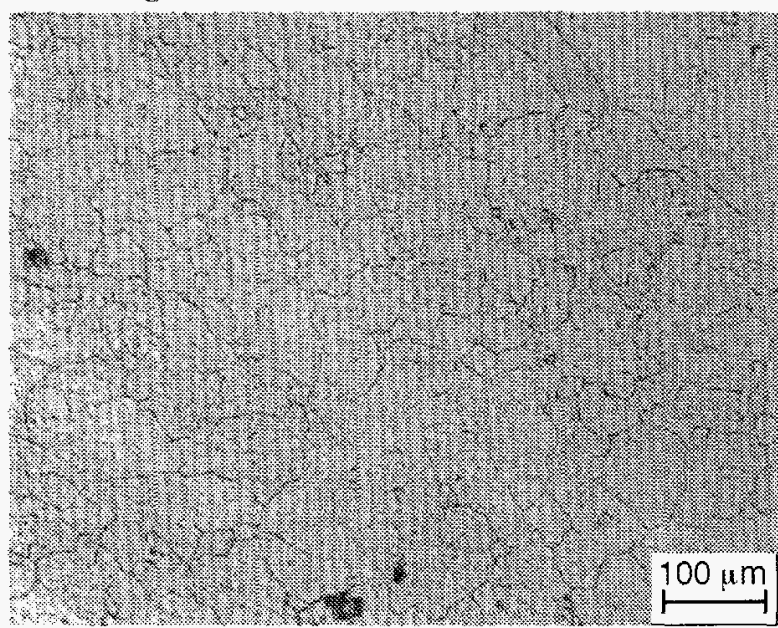

(c) Heat NX8197, mill annealed. ASTM grain size 6

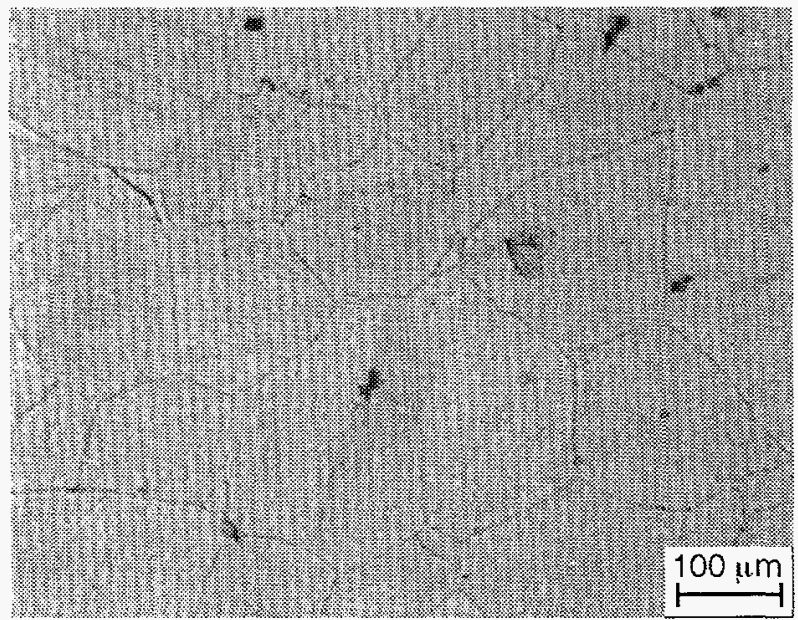

(e) NX8844G-3. hot worked at $982^{\circ} \mathrm{C} 20 \%$ reduction, ASTM grain size 2

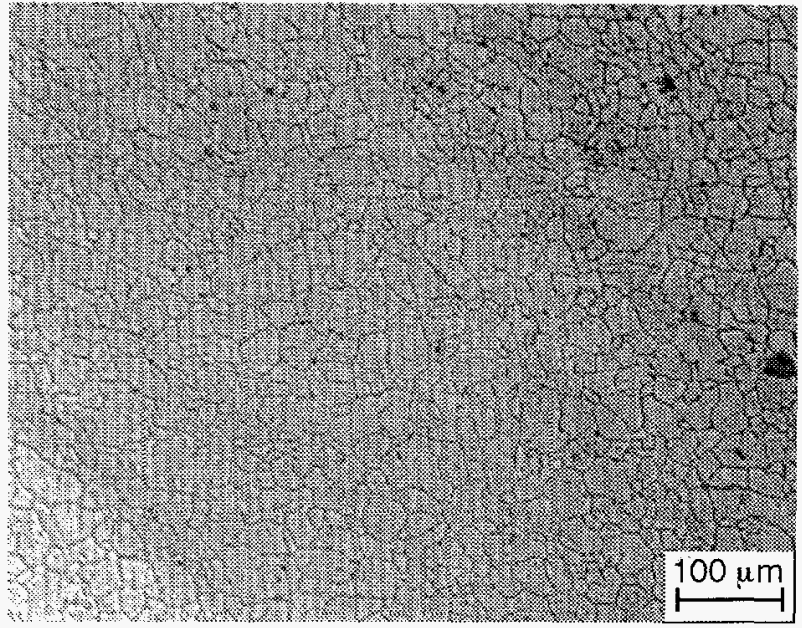

(b) Heat J422, mill annealed, ASTM grain size 7

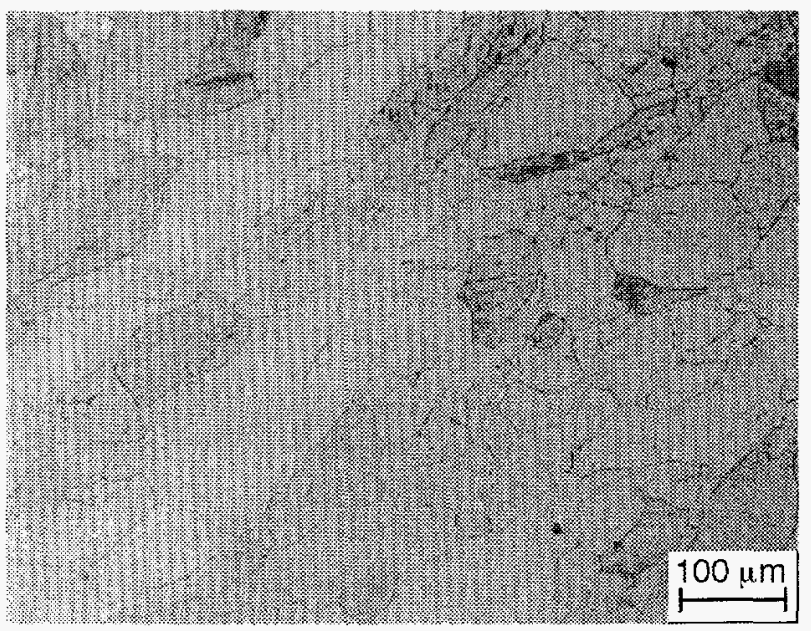

(d) Heat NX8844J-26, annealed at $1038^{\circ} \mathrm{C}$ for $1 \mathrm{~h}$, ASTM grain size 4

Figure 3. Photomicrographs used to determine grain size of various heats of Alloy 600 


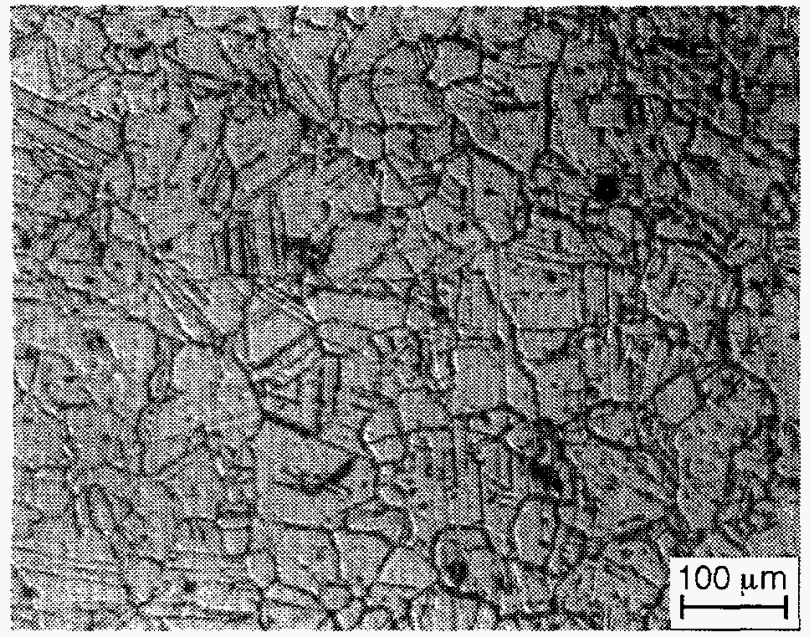

(a) Heat NX8662HG-33, annealed and thermally treated at $715^{\circ} \mathrm{C}$ for $5 \mathrm{~h}$, ASTM grain size 5

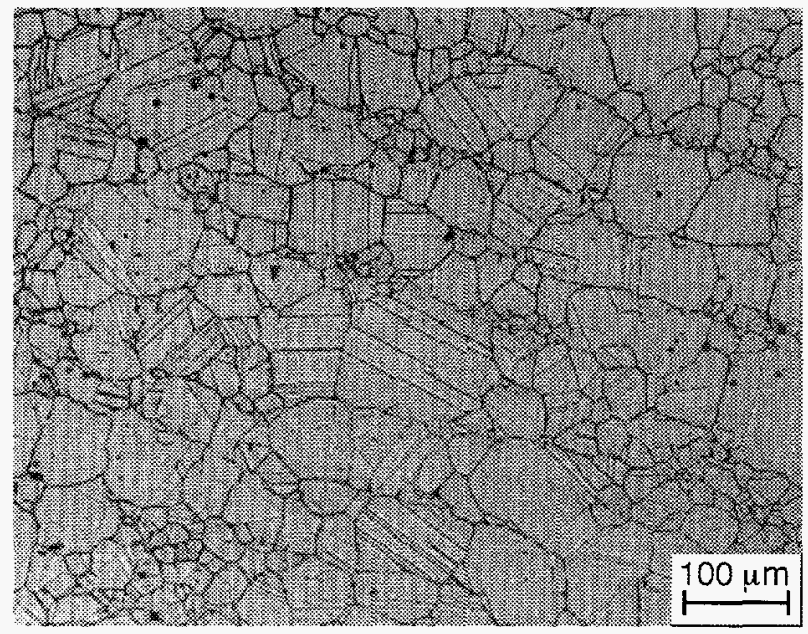

(c) Heat NX8244HK-1A, annealed at $982^{\circ} \mathrm{C}$ for $1 \mathrm{~h}$, ASTM grain size 5

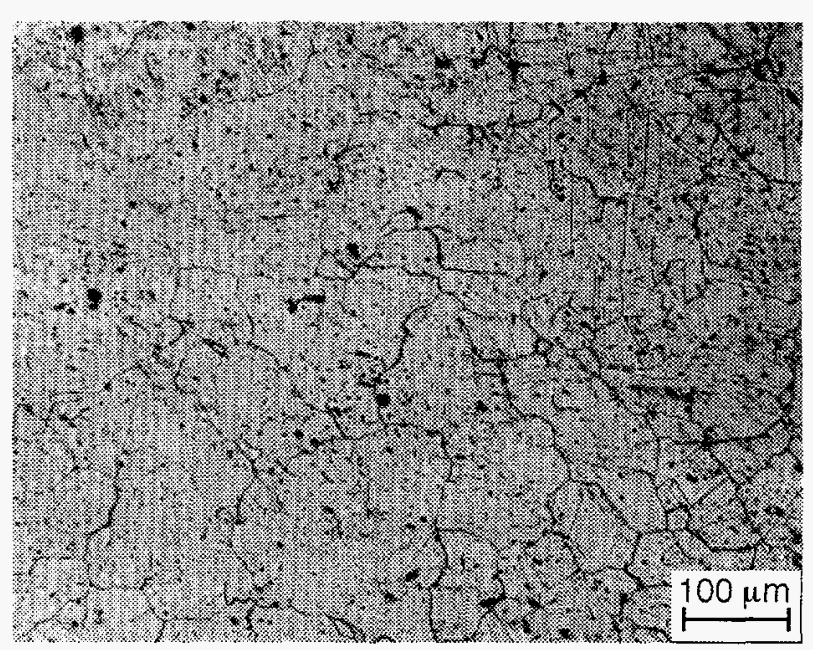

(b) Heat NX8625HG-21, annealed and thermally treated at $715^{\circ} \mathrm{C}$ for $5 \mathrm{~h}$, ASTM grain size 5

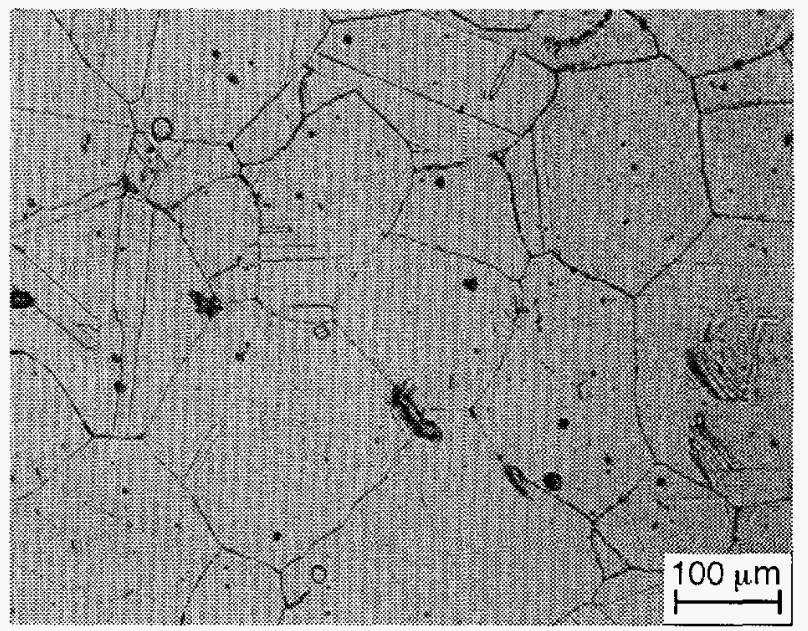

(d) Heat NX8244HK-1B, annealed at $1093^{\circ} \mathrm{C}$ for $1 \mathrm{~h}$, ASTM grain size 2

Figure 4. Photomicrographs used to determine grain size of various heats of Alloy 690

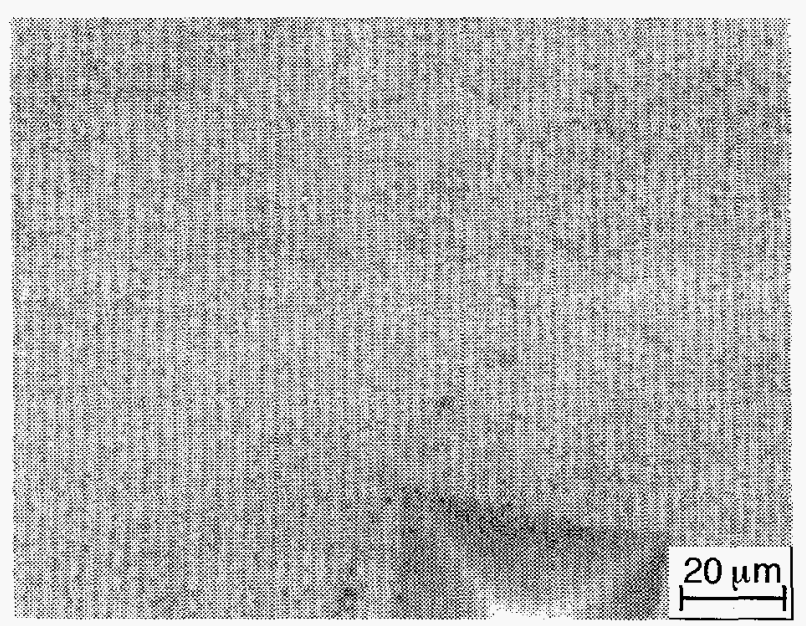

(a) Electroetched in $10 \%$ phosphoric acid solution

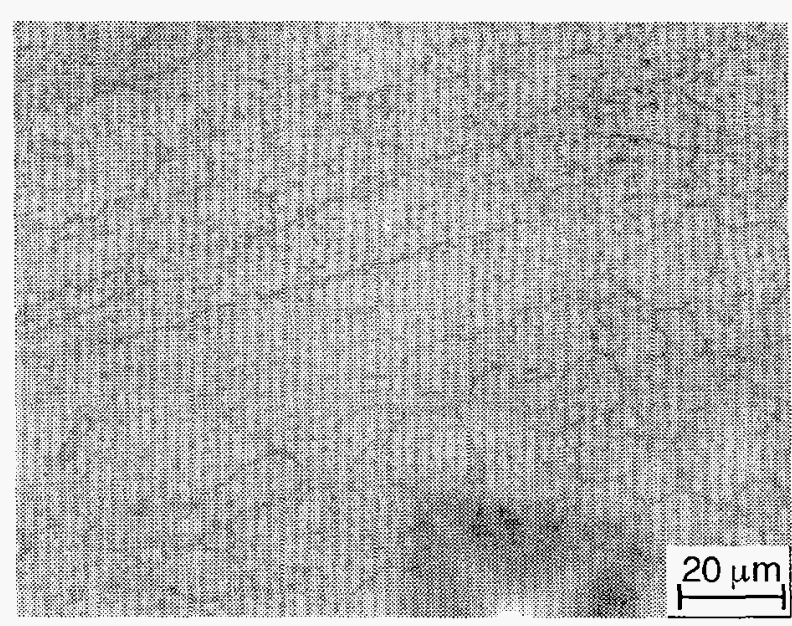

(b) Repolished and electroetched in $5 \%$ nital solution

Figure 5. Microstructures of Alloy 600, Heat NX8844B-33, that show a uniform distribution of intergranular and intragranular carbides 


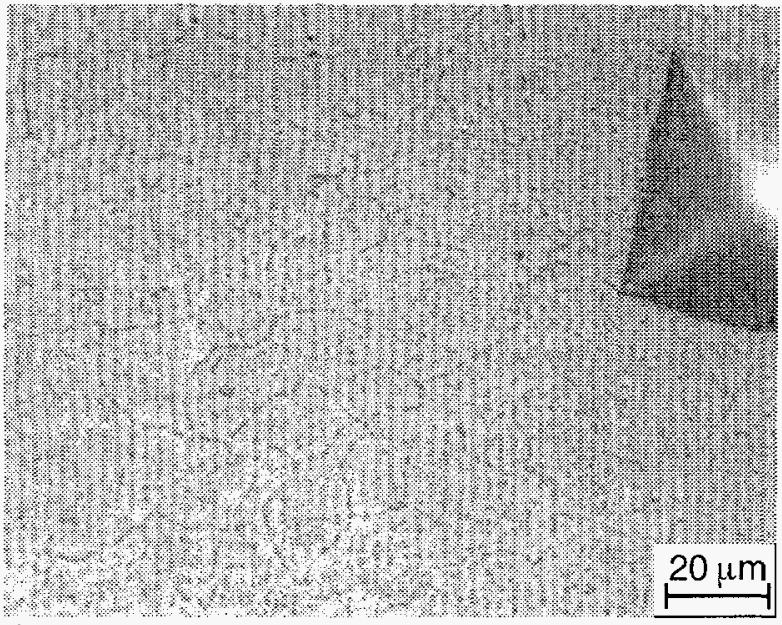

(a) Electroetched in $10 \%$ phosphoric acid solution

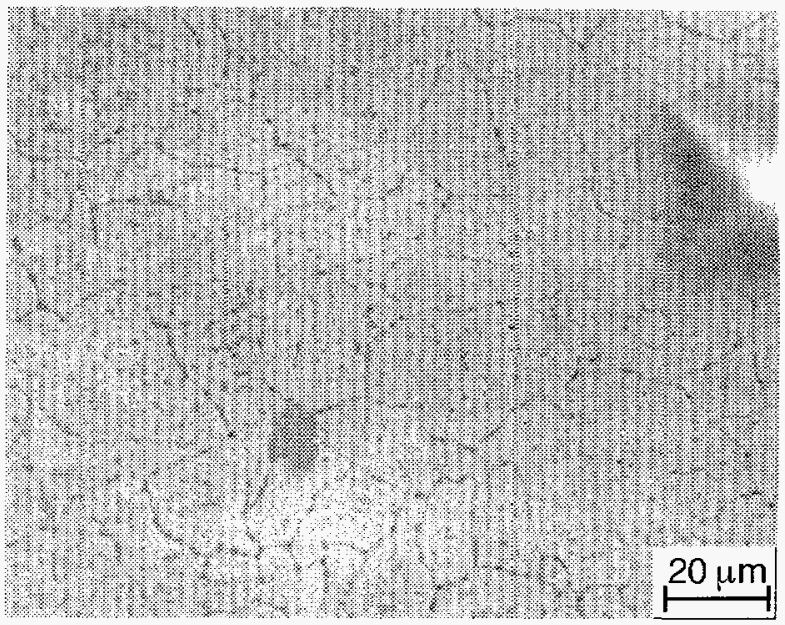

(b) Repolished and electroetched in 5\% nital solution

Figure 6. Microstructures of Alloy 600. Heat J422, that show semicontinuous intergranular and intragranular carbides

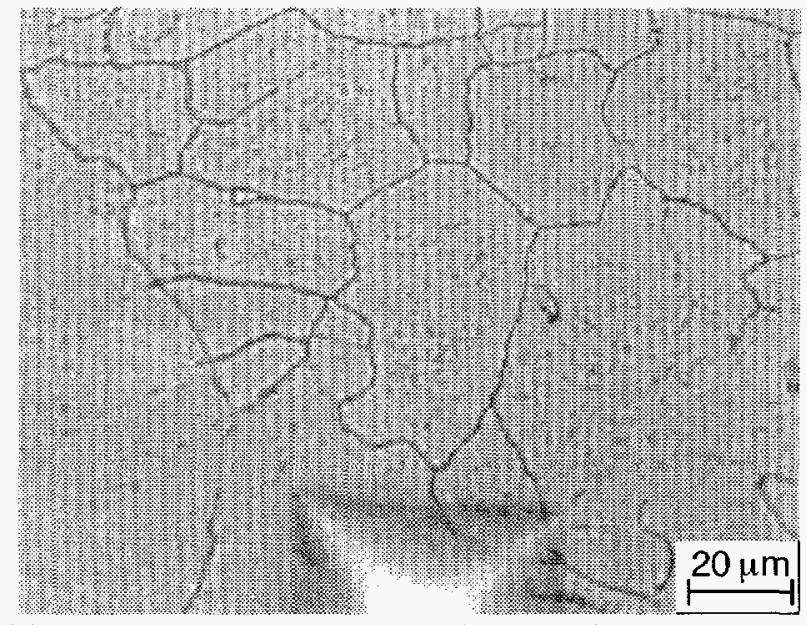

(a) Electroetched in 10\% phosphoric acid solution

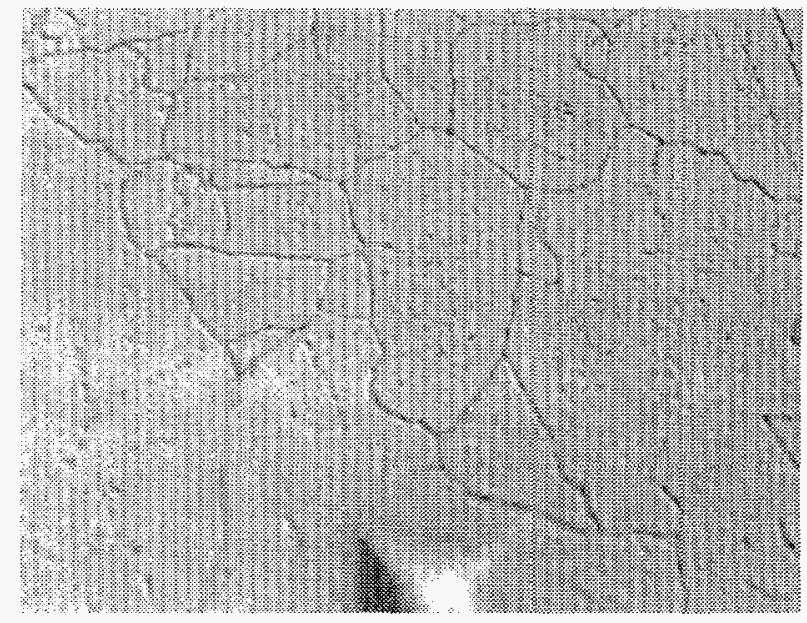

(b) Repolished and electroetched in 5\% nital solution

Figure 7. Microstructures of Alloy 600. Heat NX8197, that show continuous intergranular and intragranular carbides

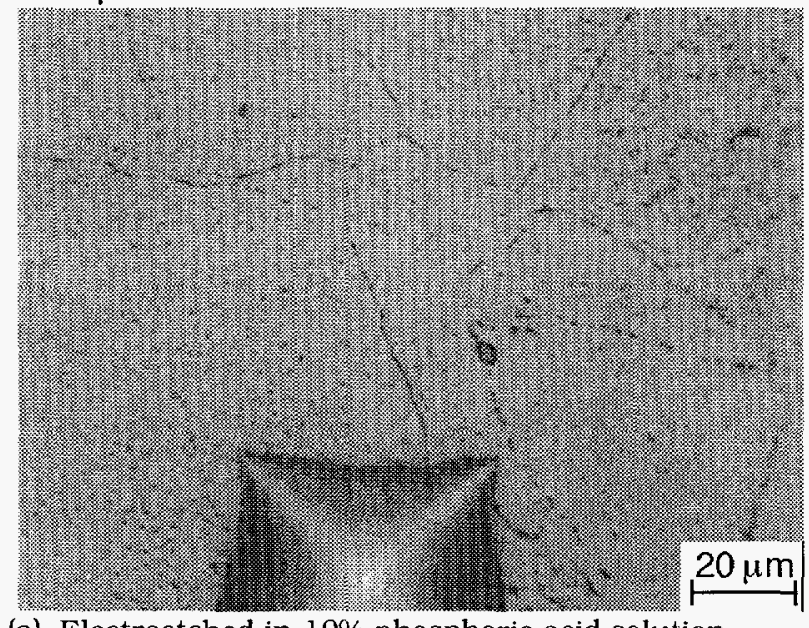

(a) Electroetched in $10 \%$ phosphoric acid solution

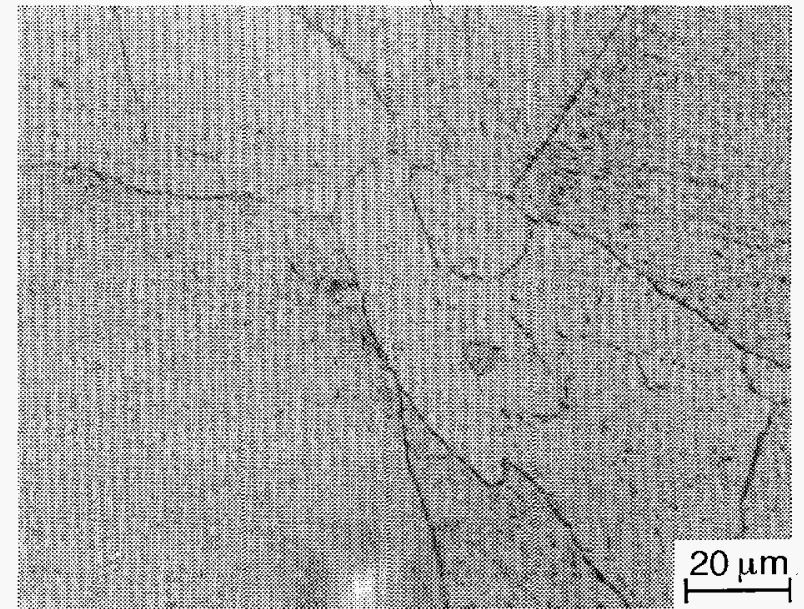

(b) Repolished and electroetched in 5\% nital solution

Figure 8. Microstructures of Alloy 600, Heat NX8844J-26, that show semicontinuous intergranular and intragranular carbides 


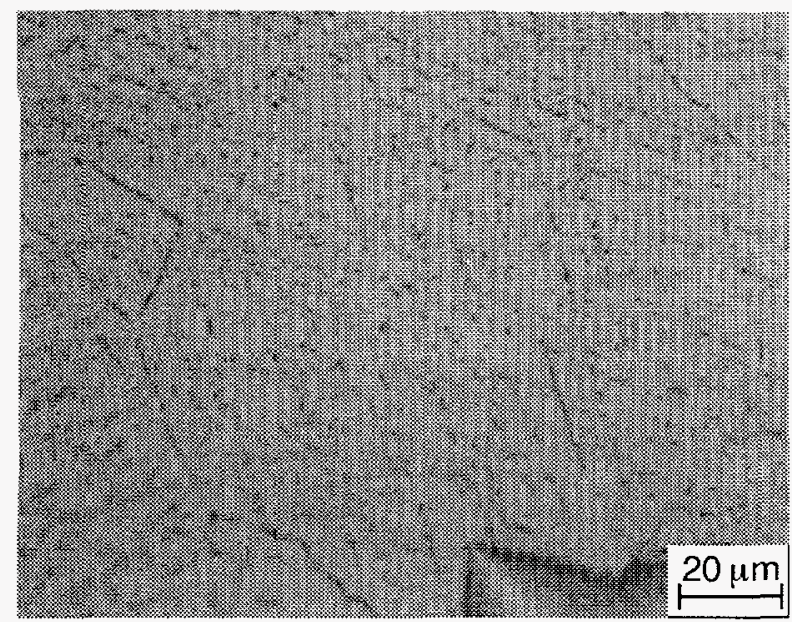

(a) Electroetched in 10\% phosphoric acid solution

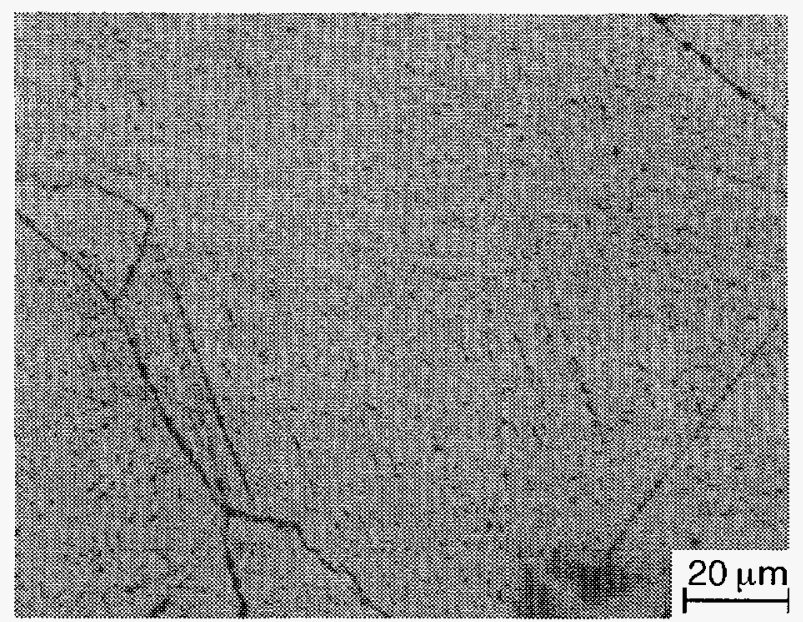

(b) Repolished and electroetched in 5\% nital solution

Figure 9. Microstructures of Alloy 600 , Heat NX8844G-3, that show semicontinuous intergranular and intragranular carbides along slip lines

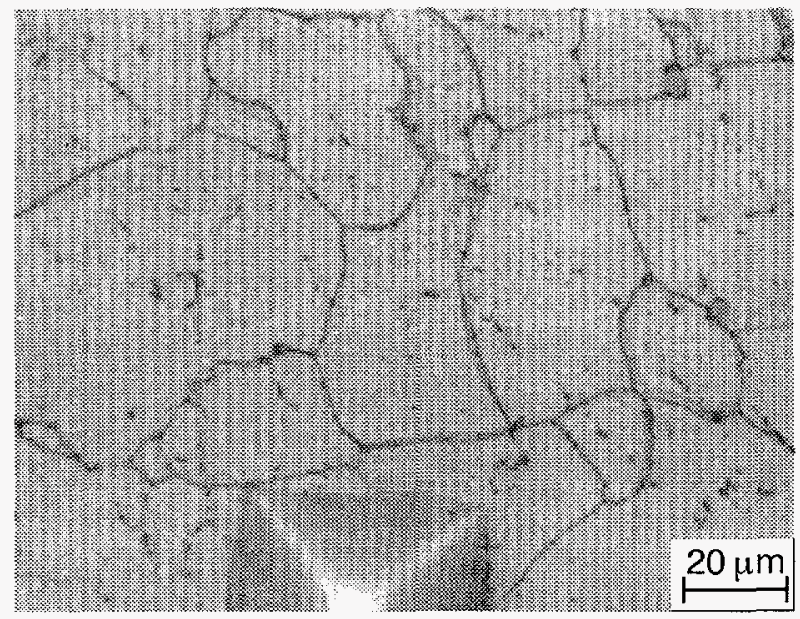

(a) Electroetched in 10\% phosphoric acid solution

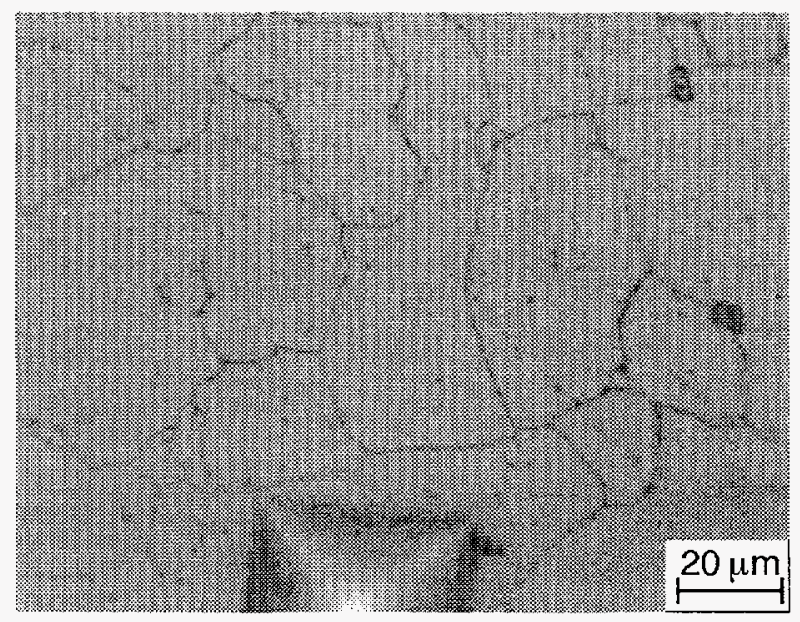

(b) Repolished and electroetched in 5\% nital solution

Figure 10. Microstructures of Alloy 690, Heat NX8662HG-33, that show continuous intergranular and relatively few intragranular carbides

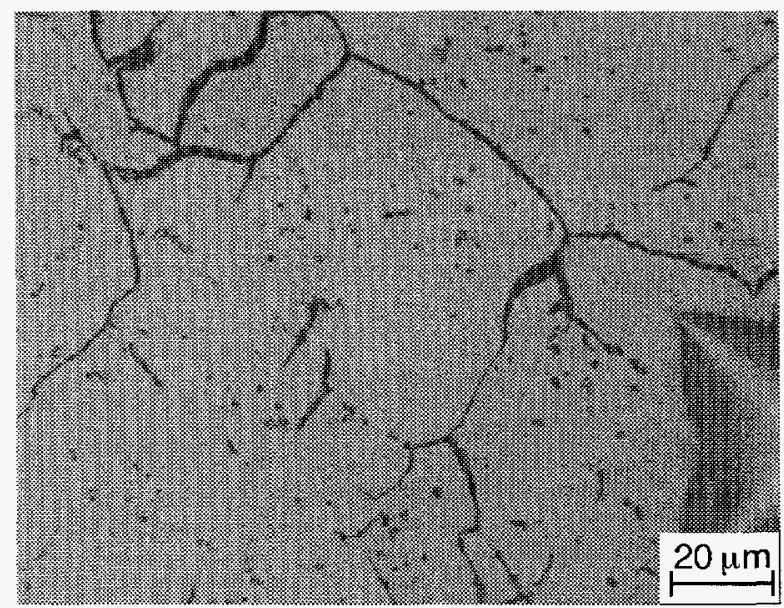

(a) Electroetched in $10 \%$ phosphoric acid solution

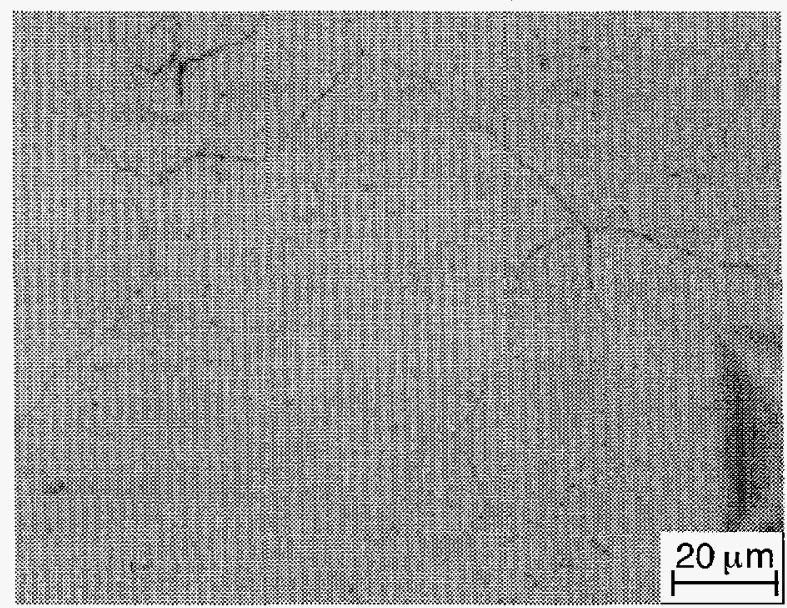

(b) Repolished and electroetched in 5\% nital solution

Figure 11. Microstructures of Alloy 690, Heat NX8625HG-21, that show continuous intergranular and some intragranular carbides 


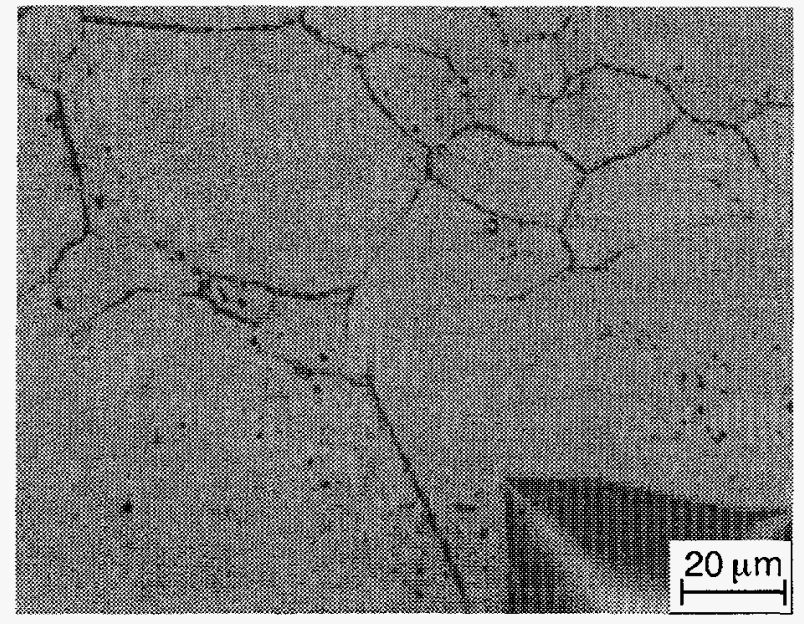

(a) Electroetched in 10\% phosphoric acid solution

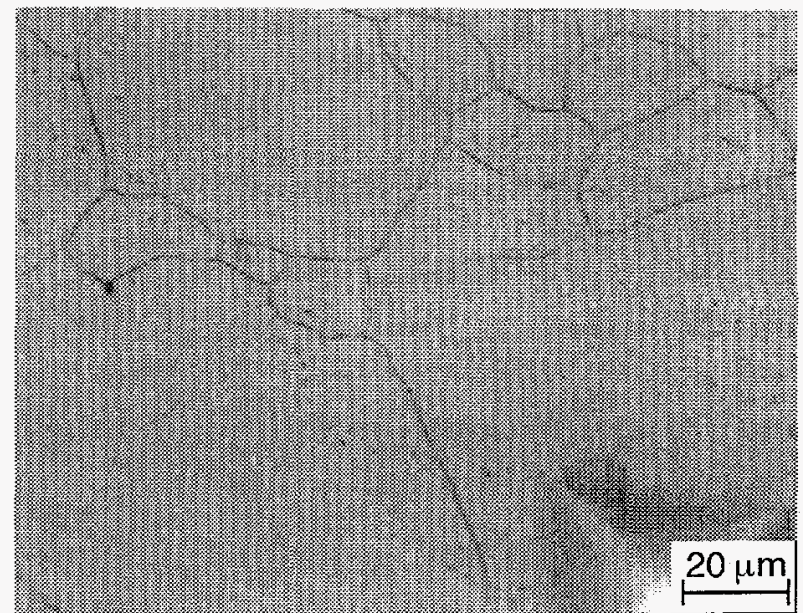

(b) Repolished and electroetched in 5\% nital solution

Figure 12. Microstructures of Alloy 690, Heat NX8244HK-1A, that show continuous intergranular but few intragranular carbides

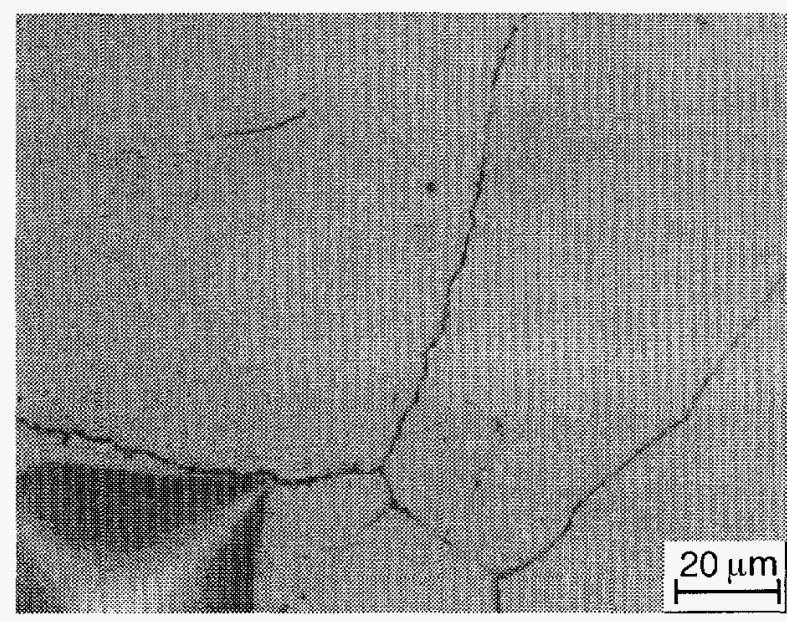

(a) Electroetched in 10\% phosphoric acid solution

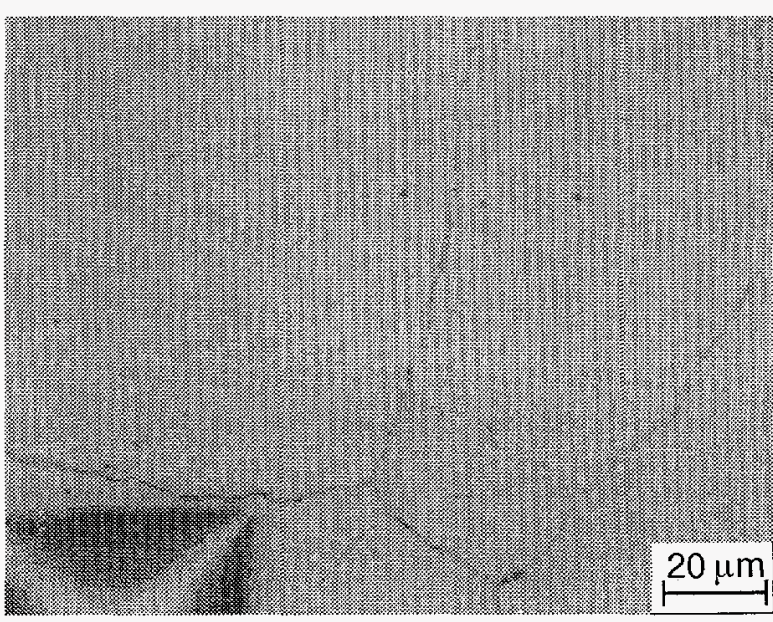

(b) Repolished and electroetched in 5\% nital solution

Figure 13. Microstructures of Alloy 690, Heat NX8844HK-1B, that show continuous intergranular but few intragranular carbides

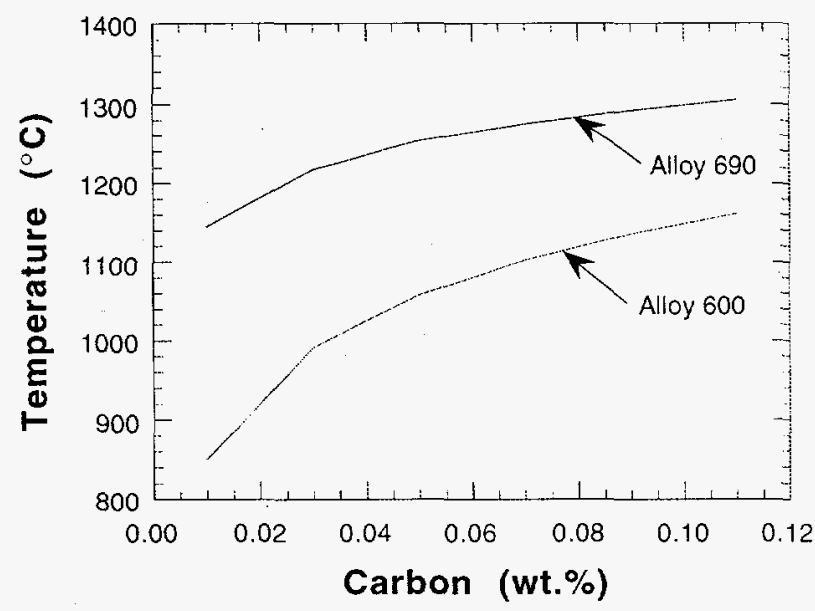

Figure 14.

Solubility of carbon in Alloys 690 and 600 vs. temperature, from Ref. 4 


\section{Fracture-Mechanics Crack Growth Tests on Alloys 600 and 690 in Simulated LWR Environments}

Crack growth experiments were performed on several sets of 1TCT specimens of Alloys 600 and 690 to explore the effects of temperature, load ratio, stress intensity, and water chemistry; namely dissolved-oxygen (DO) and -hydrogen concentrations, ionic impurities (e.g., chromate and sulfate), and two organic amines on CGRs. In this investigation, the orientation of the crack plane in the specimens corresponds to L-T identification code for plates in ASTM Specification E 399. In initial experiments, CGRs of mill-annealed Alloy 600 were compared with those of sensitized Type 304 SS. Subsequently, experiments were performed on Alloy 600 and 690 specimens in high-purity (HP) water that contained a wide range of DO $(\approx 0.001-$ $8 \mathrm{ppm})$ and hydrogen $\left(\approx 0-58 \mathrm{~cm}^{3} \mathrm{H}_{2} \cdot \mathrm{kg}^{-1} \mathrm{H}_{2} \mathrm{O}\right)$. Experiments were also performed in simulated PWR primary-system water that contained $450 \mathrm{ppm}$ boron and $2.25 \mathrm{ppm}$ lithium (added to the feedwater as $\mathrm{H}_{3} \mathrm{BO}_{3}$ and $\mathrm{LiOH}$ ), $3-58 \mathrm{~cm}^{3} \mathrm{H}_{2} \cdot \mathrm{kg}^{-1} \mathrm{H}_{2} \mathrm{O}, \approx 1 \mathrm{ppb} \mathrm{DO}$, and $750 \mathrm{ppb}$ hydrazine. Hydrazine was added to feedwater to scavenge residual DO to a very low level; however, it raised conductivity from $\approx 25$ to $42 \mu \mathrm{S} \cdot \mathrm{cm}^{-1}$. In these experiments, the role of $\mathrm{H}_{3} \mathrm{BO}_{3}$, LiOH, and dissolved hydrogen in crack growth was investigated vis-a-vis $\mathrm{HP}$ deoxygenated water. Temperature and dissolved-hydrogen concentration in water influence the stability of $\mathrm{NiO}$ on nickel-base alloys and conceivably could influence EAC of the alloys if a slip-dissolution or slip-oxidation mechanism for crack propagation was operative. CGRs of Alloys 600 and 690 were compared with values for wrought SSs in air, predicted by the ASME Code Section XI correlation at the $K_{\max }$ and load ratio values for the specimens in the various tests and by an Argonne Natioinal Laboratory (ANL) model for crack growth in water ${ }^{5}$ that was modified (see Section 3.5) to account for aqueous environments that contain $<0.2 \mathrm{ppm}$ DO. On the basis of these scoping experiments, experimental conditions will be refined to further explore the effects of alloy heat treatment, temperature, water chemistry, and loading conditions on the EAC of the materials.

\subsection{Comparison of CGRs of Sensitized Type 304 SS and Mill-Annealed Alloy 600 in Oxygenated Water}

A fracture-mechanics CGR experiment was conducted on mill-annealed Alloy 600 and two sensitized Type 304 SS specimens in simulated BWR water that contained $0.2 \mathrm{ppm}$ DO at conductivities in the range of $\approx 0.08$ to $8.3 \mu \mathrm{S} \cdot \mathrm{cm}^{-1}$. Thirteen tests were performed on a set of three specimens during an $\approx 7900 \mathrm{~h}$ period to compare CGR behavior of mill-annealed Alloy 600 (Heat No. J422) with that of sensitized Type 304 SS (electrochemical potentiokinetic reactivation [EPR] values of 6 and 17 Coulombs $\mathrm{cm}^{-2}$ ) in $\mathrm{HP}$ water and in water that contained sulfate and chromate impurities at low concentrations at $289^{\circ} \mathrm{C} .6$ The effect of two amines (2-butanone-oxime and ethanolamine) at low concentrations (1-5 ppm) on the CGR of the materials in oxygenated water was also investigated. The test conditions and experimental results are shown in Table 6. Most of the results were obtained at a load ratio $\mathrm{R}$ of 0.95 and a range of $\mathrm{K}_{\max }$ values between 28 and $41 \mathrm{MPa} \cdot \mathrm{m}^{1 / 2}$. Load ratios of 0.6 and 0.8 were used in two of the tests. The frequency and rise time of the positive sawtooth wave form were $0.077 \mathrm{~Hz}$ and $12 \mathrm{~s}$, respectively.

Experimental CGR data (a) for the three specimens are plotted in Fig. 15 vs. CGRs for wrought SSs in air ( $\dot{\mathrm{a}}_{\text {air }}$ ), predicted by the ASME Code Section XI correlation at the $\mathrm{K}_{\max }$ and 
Table-6. Crack growth results for Alloy 600 and sensitized ${ }^{a}$ Type 304 SS specimens under high-R loading in HP oxygenated water and in oxygenated water that contained chromate, sulfate, 2-butanone-oxime, or ethanolamine at $289^{\circ} \mathrm{C}$

\begin{tabular}{|c|c|c|c|c|c|c|c|c|c|c|c|c|c|c|c|c|c|c|}
\hline \multirow{4}{*}{$\begin{array}{l}\text { Test } \\
\text { No. }\end{array}$} & \multirow{4}{*}{$\begin{array}{c}\text { Test } \\
\text { Time, } \\
\text { h }\end{array}$} & \multicolumn{5}{|c|}{ Water Chemistry $c$} & \multicolumn{2}{|c|}{ Electrode Potential } & \multirow{4}{*}{$\begin{array}{l}\text { Load } \\
\text { Ratio }\end{array}$} & & & & \multicolumn{6}{|c|}{ Material (Sensitization, EPR) } \\
\hline & & \multirow{3}{*}{$\begin{array}{c}\text { Chromate } \\
\text { Conc., d } \\
\text { ppb }\end{array}$} & \multirow{3}{*}{$\begin{array}{c}\text { Sulfate } \\
\text { Conc., d } \\
\text { ppb }\end{array}$} & \multirow{3}{*}{$\begin{array}{c}\text { Other } \\
\text { Conc.. } \\
\text { ppm }\end{array}$} & \multirow{3}{*}{$\begin{array}{l}\text { Cond, } \\
\text { at } 25^{\circ} \mathrm{C} \text {, } \\
\mu S \cdot \mathrm{cm}^{-1}\end{array}$} & \multirow{3}{*}{$\begin{array}{l}\mathrm{pH} \text { at } \\
25^{\circ} \mathrm{C}\end{array}$} & \multirow{3}{*}{$\begin{array}{l}304 \mathrm{SS} \\
\mathrm{mV}(\mathrm{S}\end{array}$} & \multirow{3}{*}{${ }_{\mathrm{HE})}{ }^{\mathrm{Pt}}$} & & \multicolumn{3}{|c|}{ Alloy 600} & \multicolumn{3}{|c|}{$304 \mathrm{ss}\left(6 \mathrm{C} \cdot \mathrm{cm}^{-2}\right)$} & \multicolumn{3}{|c|}{$304 \mathrm{SS}\left(17 \mathrm{C} \cdot \mathrm{cm}^{-2}\right)$} \\
\hline & & & & & & & & & & $\mathrm{K}_{\max } \mathrm{e}^{\mathrm{e}}$ & $\Delta \mathrm{K}^{\mathrm{f}}$ & Rate, & $\mathrm{K}_{\max }{ }^{\mathrm{e}}$ & $\Delta \mathrm{K}, \mathrm{f}$ & Rate, & $\mathrm{K}_{\max } \mathrm{e}$ & $\Delta \mathrm{K}, \mathrm{f}$ & Rate, \\
\hline & & & & & & & & & & $\mathrm{MPa}$ & & $10^{-10} \mathrm{~m} \cdot \mathrm{s}^{-1}$ & & & $10^{-10} \mathrm{~m} \cdot \mathrm{s}^{-1}$ & $\mathrm{MPa} \cdot \mathrm{n}$ & & $10^{-10} \mathrm{~m} \cdot \mathrm{s}^{-1}$ \\
\hline 1 & $\begin{array}{l}530- \\
1190\end{array}$ & - & - & - & 0.09 & 6.24 & 60 & 98 & 0.95 & 28.0 & 1.40 & 0.10 & 30,4 & 1.52 & 3.1 & 30.7 & 1.54 & 3.7 \\
\hline 2 & $\begin{array}{l}1190- \\
1232\end{array}$ & - & - & - & 0.08 & 6.31 & 65 & 99 & 0.80 & 28.1 & 5.62 & 0.70 & 30.7 & 6.14 & 6.7 & 31.1 & 6.22 & 6.2 \\
\hline 3 & $\begin{array}{l}1318- \\
1344\end{array}$ & - & - & - & 0.08 & 6.31 & 58 & 84 & 0.60 & 28.4 & 11.36 & 27.0 & 31.2 & 12.48 & 19.0 & 31.4 & 12.56 & 11.0 \\
\hline 4 & $\begin{array}{l}1390- \\
1910\end{array}$ & 50 & - & - & 0.25 & 6.07 & 61 & 59 & 0.95 & 28.5 & 1.43 & 0.17 & 31.4 & 1.57 & 2.2 & 31.8 & 1.59 & 2.3 \\
\hline 5 & $\begin{array}{l}1918- \\
2380\end{array}$ & 200 & - & - & 0.74 & 5.64 & 64 & 32 & 0.95 & 28.7 & 1.44 & 0.078 & 32.4 & 1.62 & 1.4 & 32.8 & 1.64 & 1.9 \\
\hline 6 & $\begin{array}{l}2385- \\
3162\end{array}$ & 50 & 15 & - & 0.42 & 6.03 & 71 & 13 & 0.95 & 29.5 & 1.48 & 3.4 & 33.4 & 1.67 & 1.1 & 33.8 & 1.69 & 1.9 \\
\hline 7 & $\begin{array}{l}3170- \\
3832\end{array}$ & 50 & 25 & - & 0.47 & 5.93 & 76 & 37 & 0.95 & 30.6 & 1.53 & 3.3 & 34.2 & 1.71 & 1.4 & 34.3 & 1.72 & 1.2 \\
\hline 8 & $\begin{array}{l}3865- \\
4323\end{array}$ & 50 & 100 & - & 1.05 & 5.63 & 94 & 1 & 0.95 & 31.3 & 1.57 & 2.0 & 35.1 & 1.76 & 3.7 & 35.1 & 1.76 & 2.9 \\
\hline 9 & $\begin{array}{l}4395- \\
5175\end{array}$ & 50 & - & - & 0.27 & 6.11 & 53 & -23 & 0.95 & 32.0 & 1.60 & 1.5 & 35.5 & 1.78 & 0.28 & 35.3 & 1.77 & 0.14 \\
\hline 10 & $\begin{array}{l}5770- \\
6475\end{array}$ & - & - & $1.0 \mathrm{~g}$ & 0.08 & 6.23 & 139 & 166 & 0.95 & 33.8 & 1.69 & 1.4 & 37.5 & 1.88 & 2.8 & 36.9 & 1.85 & 2.0 \\
\hline 11 & $\begin{array}{l}6490- \\
7050\end{array}$ & - & - & $5.0 \mathrm{~g}$ & 0.08 & 6.41 & 163 & 235 & 0.95 & 34.6 & 1.73 & 1.8 & 39.5 & 1.98 & 4.6 & 38.8 & 1.94 & 4.5 \\
\hline 12 & $\begin{array}{l}7075- \\
7675\end{array}$ & - & - & - & 0.08 & 6.27 & 105 & 160 & 0.95 & 34.8 & 1.74 & 0.90 & 40.1 & 2.00 & 1.1 & 38.8 & 1.94 & $\approx 0$ \\
\hline 13 & $\begin{array}{l}7770- \\
7910\end{array}$ & - & - & $5.0 \mathrm{~h}$ & 8.3 & 9.60 & -3 & -221 & 0.95 & 35.5 & 1.78 & 3.0 & 41.4 & 2.07 & 7.5 & 39.1 & 1.96 & 3.9 \\
\hline
\end{tabular}

a Compact-tension specimens (1TCT) of Alloy 600 (Heat No. J422) and Type 304 SS (Heat No. 10285). The Alloy 600 specimen (No. IN-1) was tested in the

as-received mill-annealed condition. The Type $304 \mathrm{SS}$ specimens (Heat No. 10285) received a solution-anneal heat treatment at $1050^{\circ} \mathrm{C}$ for $0.5 \mathrm{~h}$

Specimen No. C34 was sensitized at $650^{\circ} \mathrm{C}$ for $2 \mathrm{~h} \cdot\left(\mathrm{EPR}=6 \mathrm{C} \cdot \mathrm{cm}^{-2}\right)$ and Specimen No. C35 at $650^{\circ} \mathrm{C} \mathrm{for} 8 \mathrm{~h}\left(\mathrm{EPR}=17 \mathrm{C} \cdot \mathrm{cm}^{-2}\right)$.

$\mathrm{b}$ Frequency and rise time of the positive sawtooth waveform were $8 \times 10^{-2} \mathrm{~Hz}$ and $12 \mathrm{~s}$, respectively.

c Effluent DO concentration was $\approx 200-300 \mathrm{ppb}$; feedwater oxygen concentration was higher by a factor of 3 to compensate for oxygen depletion by corrosion of the autoclave system.

d Chromate and sulfate were added to the feedwater as acids; average effluent chromate concentrations were $\approx 23$ and 59 ppb for feedwater levels of 50 and 200

Chromate and sulfate were added to the feedwater as acids:
ppb on the basis of colorimetric analyses of grab samples.

e Stress intensity $\mathrm{K}_{\max }$ values at the end of the time period.

f $\Delta \mathrm{K}=\mathrm{K}_{\max }(1-\mathrm{R})$, where load ratio $\mathrm{R}=\mathrm{K}_{\min } / \mathrm{K}_{\max }$.

g 2-butanone-oxime was added to the oxygenated feedwater.

$\mathrm{h}$ Ethanolamine was added to the oxygenated feedwater. 


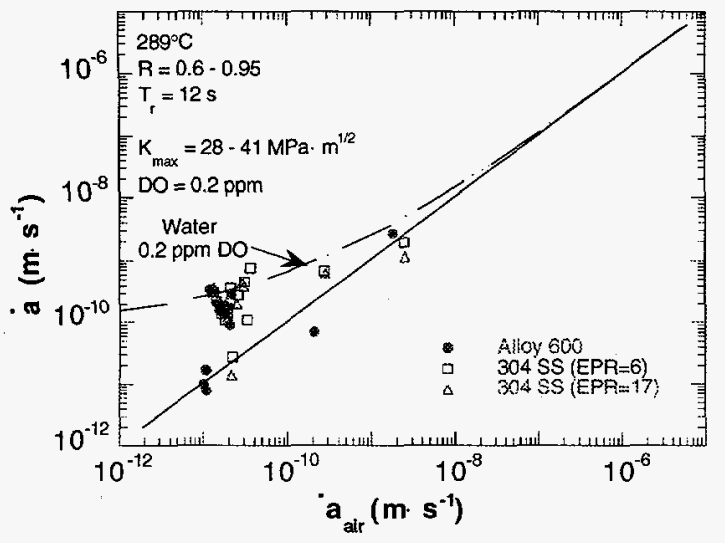

Figure 15.

Corrosion fatigue data for specimens of Alloy 600 and sensitized Type 304 SS in oxygenated water at $289^{\circ} \mathrm{C}$. Dashed line represents predictions of $A N L$ model for austenitic SSs in water with $0.2 \mathrm{ppm} D O$. Diagonal line corresponds to crack growth of SSs in air, as predicted in ASME Code.

load ratio values for the specimens in the various tests. Data for all of the materials are bounded by the two curves.

The dependence of CGRs of Alloy 600 on $K_{\max }$ at a load ratio $R$ of 0.95 is shown in Figs. 16 together with predictions for austenitic SSs in water from the ANL model and the ASME Code in air. Several data points lie near the air line predicted by the ASME Code, i.e., the rates are not environmentally enhanced. The results suggest a threshold $\mathrm{K}_{\max }$ for $\mathrm{EAC}$ of $\approx 26 \mathrm{MPa} \cdot \mathrm{m}^{1 / 2}$ at an $\mathrm{R}$ of 0.95 , i.e., CGRs at higher $\mathrm{K}_{\max }$ lie significantly above the air line.

To illustrate the relative effect of simulated BWR water $(\approx 0.2 \mathrm{ppm} D O)$ on EAC of Alloy 600 and sensitized Type 304 SS, the CGRs of Alloy 600 are plotted vs. the rates for the SS specimens under the same environmental and loading conditions in each test (Fig. 17). A data set in which the CGR of any of the three specimens was near the air line in Figs. 15 and 16 was omitted from the plot. A valid comparison of environmental effects on CGRs of the two materials can be made only when the specimens exhibit some degree of enhancement in the rates. Furthermore, CGRs of $\leq 3 \times 10^{-11} \mathrm{~m} \cdot \mathrm{s}^{-1}$ (near the air line in Figs. 15 and 16) are based on small changes in crack length that are near the sensitivity of the DC potential-drop cracklength monitoring system, namely, $5 \times 10^{-5} \mathrm{~m}$, divided by the test times of $\approx 500-800 \mathrm{~h}$. This can lead to a large uncertainty when comparing rates in this range. The results in Fig. 17 indicate that the CGR of mill-annealed Alloy 600 and sensitized Type 304 SS is virtually the same in simulated BWR water under the conditions in these tests.

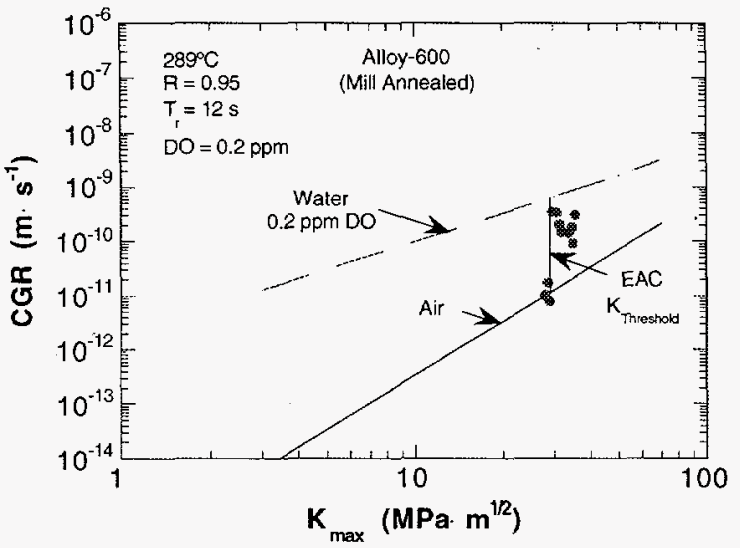

Figure 16.

Dependence of CGR of mill-annealed Alloy 600 specimen on $K_{\max }$ in oxygenated water at $289^{\circ} \mathrm{C}$. Dashed and solid lines represent predictions of ANL model for austenitic SSs in water with 0.2 ppm DO and ASME Code prediction in air, respectively, at an $R$ value of 0.95 and rise time of $12 \mathrm{~s}$. 


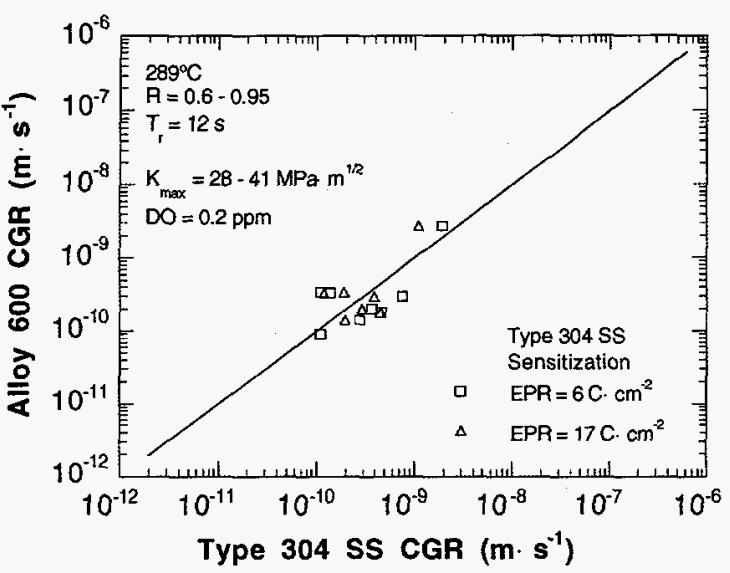

Figure 17.

CGRs of Alloy 600 and two sensitized Type 304 SS specimens under identical loading and environmental conditions at $289^{\circ} \mathrm{C}$. Solid line represents identical CGRs in Alloy 600 and Type 304 SS.

The effect of water chemistry on CGRs of the materials at a load ratio of 0.95 was explored in Tests 4-13 listed in Table 6. Additions of 50 and $200 \mathrm{ppb}$ chromate to feedwater produced modest decreases in the CGR of sensitized SS specimens (Tests 1, 4, and 5). At a load ratio of 0.95 , CGRs of the Alloy 600 specimen were lower than those of the SS specimens by a factor of $\approx 10$ and were not influenced by $50-200 \mathrm{ppb}$ chromate in oxygenated water. In Tests $6-8,15$, 25 , and $100 \mathrm{ppb}$ sulfate was added to water that contained $50 \mathrm{ppb}$ chromate and $\approx 200 \mathrm{ppb}$ DO. CGRs of the sensitized Type 304 SS specimens increased by, at most, a factor of $\approx 3$. The CGR of the Alloy 600 specimen increased from $\approx 8 \times 10^{-12}$ to $\approx 3 \times 10^{-10} \mathrm{~m} \cdot \mathrm{s}^{-1}$ when $15 \mathrm{ppb}$ sulfate was added to the feedwater (Test 6), but the rate did not increase with 25 and $100 \mathrm{ppb}$ sulfate. When sulfate was no longer added to oxygenated feedwater that contained $50 \mathrm{ppb}$ chromate (Test 9), the CGRs of both sensitized Type 304 SS specimens decreased by a factor of 10 to $\approx 1-3 \times 10^{-10} \mathrm{~m} \cdot \mathrm{s}^{-1}$; the CGR of the Alloy 600 specimen remained constant at $\approx 1 \times 10^{-10}$ $\mathrm{m} \cdot \mathrm{s}^{-1}$. In the last series of experiments (Tests 10-13), chromate was not added to the feedwater and the effect of 1 and $5 \mathrm{ppm}$ of 2-butanone-oxime or ethanolamine in water that contained $\approx 200 \mathrm{ppb}$ DO was investigated. Under these water chemistry conditions, CGRs of the SS specimens increased to their previous values of $\approx 2-4 \times 10^{-10} \mathrm{~m} \cdot \mathrm{s}^{-1}$, and once again, the Alloy 600 specimen did not respond to changes in water chemistry. These amines at concentrations of 1-5 ppm were neither beneficial nor deleterious to CGRs of the specimens.

Thus, additions of small amounts of chromate, sulfate, and the two amines to oxygenated feedwater produced small but measurable changes in CGRs of sensitized SS specimens but had virtually no effect on CGRs of the mill-annealed Alloy 600 specimen. If the effects of these species in oxygenated water are neglected, average CGRs of the Alloy 600 and sensitized Type $304 \mathrm{SS}\left(\mathrm{EPR}=6\right.$ and $17 \mathrm{C} \cdot \mathrm{cm}^{2}$ ) specimens are $2.16 \times 10^{-10}, 2.65 \times 10^{-10}$, and $2.22 \times 10^{-10}$ $\mathrm{m} \cdot \mathrm{s}^{-1}$, respectively, when $\mathrm{R}=0.95$ and $\mathrm{K}_{\max }>30 \mathrm{MPa} \cdot \mathrm{m}^{1 / 2}$. These values, i.e., $\approx 2 \times 10^{-10}$ $\mathrm{m} \cdot \mathrm{s}^{-1}$, are consistent with numerous determinations of EAC of sensitized Type 304 and nonsensitized Type $316 \mathrm{NG}$ SS specimens in oxygenated water at $289^{\circ} \mathrm{C}$ under similar loading conditions. ${ }^{7}$ We have observed that different materials, e.g., mill-annealed Alloy 600 , sensitized Type 304 , nonsensitized Type $316 \mathrm{NG}$, and $\mathrm{CF}-3, \mathrm{CF}-8$, and $\mathrm{CF}-8 \mathrm{M}$ grades of cast SSs, 8 exhibit similar CGRs in oxygenated water despite significant differences in material chemistry and microstructure. The fact that these materials exhibit different modes of crack propagation, albeit at nominally the same rate, i.e., sensitized SSs and low-carbon nuclear grade SSs exhibit intergranular and transgranular modes, respectively, whereas cracks in cast grades of austenitic SSs propagate along austenite/ferrite grain boundaries, suggests that the rate of crack propagation is controlled by the rate of cathodic reduction of DO, with a concomitant anodic dissolution process at the crack tip. 


\subsection{Comparison of CGRs of Mill-Annealed Alloy 600, Sensitized Type 304 SS, and Type 316NG SS in Oxygenated Water and in Simulated PWR Water}

CGRs of mill-annealed Alloy 600 (Heat No. J422), Type 316NG, and sensitized Type 304 SS (EPR $=20 \mathrm{C} \cdot \mathrm{cm}^{-2}$ ) were determined at high load ratios in simulated PWR water at $289^{\circ} \mathrm{C}$. Initial tests were conducted in water that contained $450 \mathrm{ppm}$ boron and $2.25 \mathrm{ppm}$ lithium (added to the feedwater as $\mathrm{H}_{3} \mathrm{BO}_{3}$ and $\mathrm{LiOH}$ ), $4.1 \mathrm{~cm}^{3} \mathrm{H}_{2} \cdot \mathrm{kg}^{-1} \mathrm{H}_{2} \mathrm{O}$, $\approx 1 \mathrm{ppb} \mathrm{DO}$, and $750 \mathrm{ppb}$ hydrazine. Room-temperature $\mathrm{pH}$ and conductivity were $\approx 7.2$ and $42 \mu \mathrm{S} \cdot \mathrm{cm}^{-1}$, respectively. Hydrazine was added to the feedwater to scavenge residual DO to a very low level; however, it raised conductivity from $\approx 25$ to $42 \mu \mathrm{S} \cdot \mathrm{c} \mathrm{m}^{-1}$. Effluent DO and dissolved hydrogen concentrations were determined by Orbisphere oxygen and hydrogen meters. The Alloy 600 specimen was mill annealed and the Type $316 \mathrm{NG}$ and 304 SS specimens were solution annealed at $1050^{\circ} \mathrm{C}$ for $0.5 \mathrm{~h}$ and given sensitization heat treatments at $650^{\circ} \mathrm{C}$ for $24 \mathrm{~h}(\mathrm{EPR}=$ $\left.0 \mathrm{C} \cdot \mathrm{cm}^{-2}\right)$ and at $700^{\circ} \mathrm{C}$ for $12 \mathrm{~h}\left(\mathrm{EPR}=20 \mathrm{C} \cdot \mathrm{cm}^{-2}\right)$, respectively. CGRs were determined by the DC potential-drop method.

The usual technique to initiate fatigue cracks in specimens at $289^{\circ} \mathrm{C}$ in a test environment where $K_{\max }$ is $20 \mathrm{MPa} \cdot \mathrm{m}^{1 / 2}$, load ratio is 0.2 , and frequency is $10 \mathrm{~Hz}$ was successful for the SS specimens, but a fatigue crack did not initiate in the Alloy 600 specimen. In an attempt to initiate a crack in the latter specimen, the $\mathrm{K}_{\max }$ and load ratio were increased to $30 \mathrm{MPa} \cdot \mathrm{m}^{1 / 2}$ and 0.8 , respectively. Under these conditions, CGRs of the Type $316 \mathrm{NG}$ and 304 SS specimens were $\approx 3.0 \times 10^{-10}$ and $2.3 \times 10^{-9} \mathrm{~m} \cdot \mathrm{s}^{-1}$, respectively, but once again, no crack growth occurred in the Alloy 600 specimen (Test 1 in Table 7). Because of the high CGRs of the SS specimens, the load ratio was increased from 0.8 to 0.9 in the next test. Under this condition, crack growth occurred in the Alloy 600 specimen, but the DC potentialdrop measurements indicated small negative CGRs for both SS specimens. Although we could not identify the origin of the problem, we have never encountered this behavior in tests in simulated BWR water. Consequently, the water chemistry was changed from simulated primary PWR water to HP water that contained $\approx 6 \mathrm{ppm}$ DO for a series of tests at load ratios between 0.2 and 1.0 (Tests $3-8$ in Table 7 ). In this environment, CGRs were determined for the three specimens. Then, another attempt was made to determine CGRs in simulated PWR water by the DC potential-drop method in Tests 9 and 10. Once again, data for one of the SS specimens became erratic but results for the other and the Alloy 600 specimen exhibited normal variability. In the last test (No. 10), the hydrogen concentration was increased from $\approx 4$ to $45 \mathrm{~cm}^{3} \cdot \mathrm{kg}^{-1}$ to determine its effect on the CGR of the Alloy 600 specimen at a load ratio of 0.8 and $\mathrm{a} \mathrm{K}_{\max }$ of $\approx 31 \mathrm{MPa} \cdot \mathrm{m}^{1 / 2}$. This hydrogen concentration decreased the CGR of the Alloy 600 specimen by a factor of $\approx 40$ and increased by $45 \%$ the CGR of the Type $316 N G$ SS specimen. The experiment was terminated and the system was reconfigured to utilize the crack-opening-displacement (COD) compliance technique for crack length measurements on specimens of Alloys 600 and 690 in simulated PWR water with a range of hydrogen concentrations.

Experimental CGR data for the Alloy 600 and Type 304 and $316 \mathrm{NG}$ SS specimens in HP water that contained $\approx 6 \mathrm{ppm}$ DO are plotted in Fig. $18 \mathrm{vs}$. CGRs predicted for wrought SSs in air by the ASME Code Section XI correlation at the $K_{\max }$ and load ratio values for the specimens in the various tests. With the exception of one data point for Alloy 600 , the results are bounded by the two curves. 
Table 7. Crack growth results for Alloy 600, Type 316NG, and sensitized ${ }^{a}$ Type 304 SS specimens in simulated PWR and HP oxygenated water at $289^{\circ} \mathrm{C}$

\begin{tabular}{|c|c|c|c|c|c|c|c|c|c|c|c|c|c|c|c|c|c|c|c|}
\hline \multirow{3}{*}{$\begin{array}{l}\text { Test } \\
\text { No. }\end{array}$} & \multirow{3}{*}{$\begin{array}{c}\text { Test } \\
\text { Time, } \\
\text { h }\end{array}$} & \multicolumn{6}{|c|}{ Water Chemistry } & \multirow{2}{*}{\multicolumn{2}{|c|}{ Electrode Potential }} & \multirow{3}{*}{$\begin{array}{l}\text { Load } \\
\text { Ratiod }\end{array}$} & \multirow{2}{*}{\multicolumn{3}{|c|}{ Alloy 600}} & \multirow{2}{*}{\multicolumn{3}{|c|}{$316 \mathrm{NG}$ SS }} & \multirow{2}{*}{\multicolumn{3}{|c|}{$\begin{array}{c}\text { Material Sensitization } \\
304 \mathrm{SS}\left(20 \mathrm{C} \cdot \mathrm{cm}^{-2}\right) \\
\end{array}$}} \\
\hline & & \multirow{2}{*}{$\begin{array}{c}\mathrm{B}^{\mathrm{b}} \\
\text { Conc., } \\
\mathrm{ppm}\end{array}$} & \multirow{2}{*}{$\begin{array}{c}\mathrm{Li}^{\mathrm{b}} \\
\text { Conc., } \\
\text { ppm }\end{array}$} & \multirow{2}{*}{$\begin{array}{c}\mathrm{H}_{2}{ }^{\mathrm{c}} \\
\text { Conc., } \\
\mathrm{cc} \cdot \mathrm{k} \mathrm{g} \mathrm{g}^{-1}\end{array}$} & \multirow{2}{*}{$\begin{array}{c}\mathrm{O}_{2^{\mathrm{c}}} \\
\text { Conc. } \\
\mathrm{ppm}\end{array}$} & \multirow{2}{*}{$\begin{array}{l}\text { Cond. } \\
\text { at } 25^{\circ} \mathrm{C} \text {, } \\
\mu \mathrm{S} \cdot \mathrm{cm}^{-1}\end{array}$} & \multirow{2}{*}{$\begin{array}{l}\text { pH at } \\
25^{\circ} \mathrm{C}\end{array}$} & & & & & & & & & & & & \\
\hline & & & & & & & & $\begin{array}{r}304 \mathrm{SS} \\
\mathrm{mV}\end{array}$ & $\begin{array}{l}\text { Alloy } 600 \\
\text { SHE) }\end{array}$ & & $\begin{array}{r}\mathrm{K}_{\max } \mathrm{e}, \\
\mathrm{MPa}\end{array}$ & $\begin{array}{l}\Delta K, f \\
1 / 2\end{array}$ & $\begin{array}{c}\text { Rate, } \\
10^{-10} \mathrm{~m} \cdot \mathrm{s}^{-1}\end{array}$ & $\begin{array}{l}\mathrm{K}_{\max } \mathrm{e} \\
\mathrm{MPa} \cdot \mathrm{m}\end{array}$ & $\Delta \mathrm{K}, \mathrm{f}$ & $\begin{array}{l}\text { Rate, } \\
10^{-10} \mathrm{~m} \cdot \mathrm{s}^{-1}\end{array}$ & $\begin{array}{l}\mathrm{K}_{\max } \mathrm{e} \\
\mathrm{MPa} \cdot \mathrm{m}\end{array}$ & $\begin{array}{l}\Delta \mathrm{K}, \mathrm{f} \\
1 / 2\end{array}$ & $\begin{array}{c}\text { Rate, } \\
10^{-10} \mathrm{~m} \cdot \mathrm{s}^{-1}\end{array}$ \\
\hline 1 & $\begin{array}{c}74- \\
113\end{array}$ & 450 & 2.25 & 4.1 & $0.001 \mathrm{~g}$ & 41.7 & 7.23 & -666 & -668 & 0.8 & 29.4 & 5.88 & $-\mathrm{h}$ & 30.3 & 6.06 & 2.97 & 31.0 & 6.20 & 22.9 \\
\hline 2 & $\begin{array}{l}118- \\
230\end{array}$ & 450 & 2.25 & 4.1 & $0.001 \mathrm{~g}$ & 41.7 & 7.27 & -731 & -693 & 0.9 & 29.4 & 2.94 & 0.96 & 30.3 & 3.03 & h & 31.0 & 3.10 & $-\mathrm{h}$ \\
\hline 3 & $\begin{array}{l}304- \\
327\end{array}$ & 0 & 0 & 0 & 6.0 & 0.07 & 6.09 & 122 & 45 & 0.8 & 31.7 & 6.34 & 2.67 & 30.4 & 6.08 & 15.8 & 32.3 & 6.46 & 43.5 \\
\hline 4 & $\begin{array}{l}335- \\
397\end{array}$ & 0 & 0 & 0 & 6.0 & 0.07 & 6.09 & 122 & 45 & 1.0 & 5.8 & 0 & $-\mathrm{h}$ & 5.6 & 0 . & 0.27 & 6.0 & 0 & 2.95 \\
\hline 5 & $\begin{array}{l}409- \\
422\end{array}$ & 0 & 0 & 0 & 5.8 & 0.07 & 6.09 & 128 & 48 & 1.0 & 15.8 & 0 & 0.48 & 15.5 & 0 & 0.72 & 16.5 & 0 & 2.13 \\
\hline 6 & $\begin{array}{l}471- \\
481\end{array}$ & 0 & 0 & 0 & 5.8 & 0.07 & 6.09 & 142 & 53 & 0.5 & 31.7 & 15.85 & 2.37 & 32.0 & 16.00 & 189.0 & 33.6 & 16.80 & 95.0 \\
\hline 7 & $\begin{array}{l}495- \\
501\end{array}$ & 0 & 0 & 0 & 5.8 & 0.07 & 6.09 & 142 & 53 & 0.2 & 33.1 & 26.48 & 98.0 & 39.2 & 31.36 & 399.0 & 40.5 & 32.40 & 361.0 \\
\hline 8 & $\begin{array}{l}504- \\
545\end{array}$ & 0 & 0 & 0 & 5.2 & 0.07 & 6.09 & 142 & 55 & 0.8 & 32.7 & 6.54 & 5.72 & 38.9 & 7.78 & 13.4 & 40.3 & 8.06 & 22.8 \\
\hline 9 & $\begin{array}{l}640- \\
688\end{array}$ & 450 & 2.25 & 4.0 & $0.001 \mathrm{~g}$ & 38.5 & 7.55 & -748 & -766 & 0.8 & 30.7 & 6.14 & 16.0 & 39.7 & 7.94 & 31.0 & - & - & $-i$ \\
\hline 10 & $\begin{array}{l}718- \\
788\end{array}$ & 450 & 2.25 & 45.3 & $0.001 \mathrm{~g}$ & 41.6 & 7.31 & -783 & -315 & 0.8 & 30.7 & 6.14 & 0.36 & 42.5 & 8.50 & 45.0 & - & - & $-\mathbf{i}$ \\
\hline
\end{tabular}

a Compact tension specimens (1TCT) of Alloy 600 (Heat No. J422), Type 316NG (Heat No. 13198), and Type 304 SS (Heat No. 30956). The Alloy 600 specimen
(No. IN-2) was tested in the as-received mill-annealed condition. Type 316NG and 304 SS specimens (Nos. 198-2 and 37, respectively) received a solutionanneal heat treatment at $1050^{\circ} \mathrm{C}$ for $0.5 \mathrm{~h}$ and were given sensitization heat treatments at $650^{\circ} \mathrm{C}$ for $24 \mathrm{~h}(\mathrm{EPR}=\sim 0 \mathrm{C} \cdot \mathrm{cm}-2, \mathrm{No}$. $198-2)$ and at $700^{\circ} \mathrm{C}$ for $12 \mathrm{~h}$ $\left(\mathrm{EPR}=20 \mathrm{C} \cdot \mathrm{cm}^{-2}\right.$, No. 37$)$

$\mathrm{b}$ Boron and lithium were added to the feedwater as $\mathrm{H}_{3} \mathrm{BO}_{3}$ and $\mathrm{LiOH}$.

c Effluent dissolved hydrogen and DO concentrations were determined with Orbisphere hydrogen and oxygen meters.

d Frequency and rise time of the positive sawtooth waveform were $8 \times 10^{-2} \mathrm{~Hz}$ and $12 \mathrm{~s}$, respectively, at load ratio values of $<1.0$.

e Stress intensity $K_{\max }$ values at the end of the time period.

$\mathrm{f}_{\Delta \mathrm{K}}=\mathrm{K}_{\max }(1-\mathrm{R})$, where load ratio $\mathrm{R}=\mathrm{K}_{\min } / \mathrm{K}_{\max }$.

$g$ Effluent DO concentration was $\approx 1 \mathrm{ppb} ; \approx 750 \mathrm{ppb}$ hydrazine was added to deoxygenated feedwater to scavenge residual DO.

h Crack length measured by the DC potential-drop method indicated small negative CGRs.

i The DC potential-drop method indicated eratic large negative CGRs. 


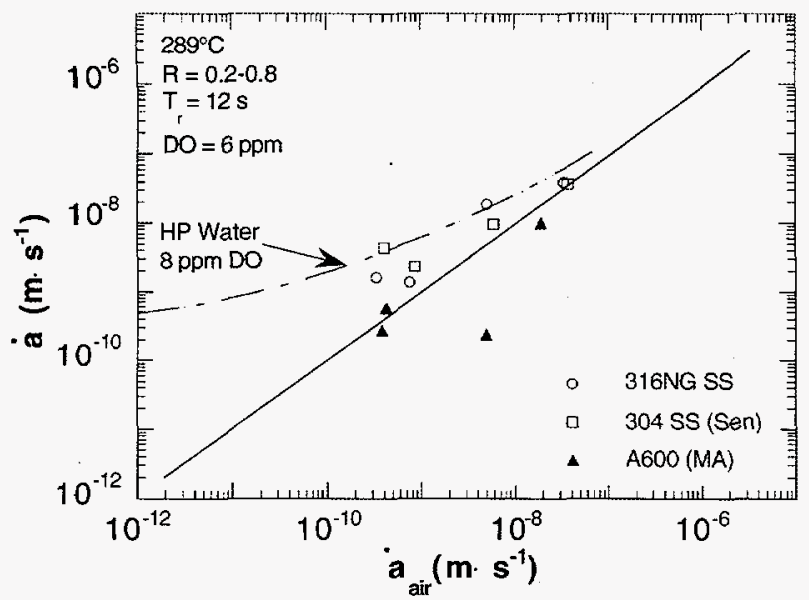

Figure 18.

Corrosion fatigue data for specimens of Alloy 600, Type 316NG and sensitized Type 304 SS in oxygenated water at $289^{\circ} \mathrm{C}$. Dashed line represents predictions of $A N L$ model for austenitic SSs in water containing 8 ppm DO. Diagonal line corresponds to crack growth of SSs in air.

Figure 19 shows experimental CGR data for the Alloy 600 and Type 304 and 316NG SS specimens in simulated PWR primary-system water that contained $\approx 1 \mathrm{ppb}$ DO versus CGRs predicted for wrought SSs in air by the ASME Section XI correlation at the $K_{\max }$ and load ratio values for the specimens in the various tests. The dashed line represents the ANL model prediction for crack growth in water that contains $\approx 1 \mathrm{ppb} D O$ and no contribution from stress corrosion cracking in the low-oxygen environment. With the exception of one data point for the Alloy 600 specimen, the experimental results are bounded by the predictions of the ANL model and the air line for austenitic SSs predicted by the ASME Code. Additional CGR data for austenitic SS specimens are required to validate model predictions in water that contains low DO concentrations.

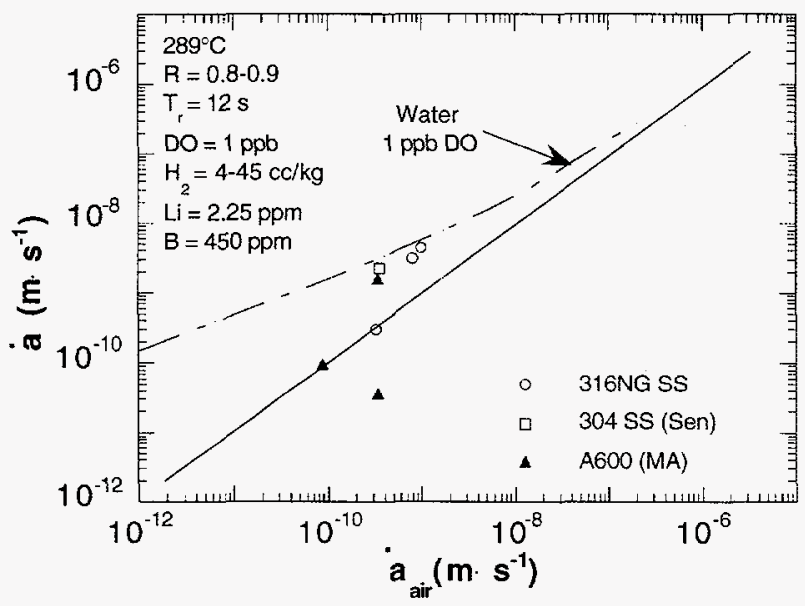

Figure 19.

Corrosion fatigue data for specimens of Alloy 600, Type 316NG and sensitized Type 304 SS in simulated PWR primary water at $289^{\circ} \mathrm{C}$. Dashed line represents predictions of ANL model for austenitic SSs in water containing 1 ppb DO. Diagonal line corresponds to crack growth of SSs in air.

\subsection{CGRs of Mill-Annealed Alloy 600 and Thermally Treated Alloy 690 in HP Water at 289 and $320^{\circ} \mathrm{C}$}

The effects of temperature, DO in HP water, and dissolved hydrogen in low-DO water on CGRs of Alloys 600 and 690 is being investigated. In the latter environment, the concentration of dissolved hydrogen in the water can influence the nature of corrosionproduct films on nickel-base alloys, and thereby play a role in the crack growth process. The manner in which temperature and dissolved hydrogen in low-DO water can affect the stability of $\mathrm{NiO}$ on nickel and Alloy 600 (75 wt.\% nickel) is outlined below. 


\subsubsection{Thermodynamic Stability of NiO Corrosion Product on Nickel-Base Alloys as a Function of Hydrogen Concentration of Water and Temperature}

Under conditions where chemical oxidation of nickel occurs in water (Eq. 1), atomic hydrogen forms; some is absorbed by the alloy and can contribute to EAC, 9,10 the remainder is released to the coolant.

$$
\mathrm{Ni}(\mathrm{s})+\mathrm{H}_{2} \mathrm{O}_{(\mathrm{g})}=\mathrm{NiO}_{(\mathrm{s})}+\mathrm{H}_{2}(\mathrm{~g}) \text {. }
$$

The free-energy change $\Delta \mathrm{G}_{\mathrm{T}}$ of the reaction is given by

$$
\Delta \mathrm{G}_{\mathrm{T}}=\Delta \mathrm{G}_{\mathrm{T}}^{\circ}+\mathrm{RT} \ln \mathrm{K},
$$

where $\Delta G^{\circ} \mathrm{T}$ is the difference in the standard free energies of formation of $\mathrm{NiO}$ and $\mathrm{H}_{2} \mathrm{O}$, $R$ is the molar gas constant, and $K$ is the equilibrium constant of the reaction;

$$
\mathrm{K}=\frac{\mathrm{a}_{\mathrm{NiO}}}{\mathrm{a}_{\mathrm{Ni}}} \cdot \frac{\mathrm{a}_{\mathrm{H}_{2}}}{\mathrm{a}_{\mathrm{H}_{2} \mathrm{O}}} \text {. }
$$

If hydrogen obeys the ideal gas law in the vapor phase, and for dilute solutions of hydrogen in water; the partial pressure of hydrogen in the vapor is given by

$$
\mathrm{pH}_{2}=\mathrm{N} \cdot \mathrm{x},
$$

where $\mathrm{N}$ is Henry's Law constant for hydrogen dissolved in water and $\mathrm{x}$ is the mole fraction of hydrogen gas in water.

Because the standard free energies of formation of $\mathrm{NiO}$ and $\mathrm{H}_{2} \mathrm{O}$ are similar in magnitude, the standard driving force $\Delta \mathrm{G}^{\circ} \mathrm{T}$ for the reaction is small $\left(\Delta \mathrm{G}^{\circ} \mathrm{T}=550+10.18 \mathrm{~T} \text { cal }\right)^{10}$ and a high enough concentration of hydrogen in water could prevent formation of the $\mathrm{NiO}$ phase. For a constant hydrogen concentration in water, the $\mathrm{pH}_{2} / \mathrm{pH}_{2} \mathrm{O}$ ratio decreases as temperature increases because (a) the temperature dependence of Henry's Law constant $\mathrm{N}$ and thereby $\mathrm{pH}_{2}$ decreases with temperature, and (b) the saturation pressure of water $\mathrm{pH}_{2} \mathrm{O}$ sat increases with temperature, i.e., $\mathrm{pH}_{2} \mathrm{O} \approx \mathrm{pH}_{2} \mathrm{O}$ sat. The dependence on temperature of $\Delta \mathrm{G}_{\mathrm{T}}$ for the reaction in Eq. 1 for 2 and $60 \mathrm{~cm}^{3} \mathrm{H}_{2} \cdot \mathrm{kg}^{-1} \mathrm{H}_{2} \mathrm{O}$ is shown in Fig. 20. The $\mathrm{NiO}$ phase is not stable at positive values of $\Delta \mathrm{G}_{\mathrm{T}}$. Figure 21 shows the calculated range of stability of $\mathrm{NiO}$ as a function of temperature and hydrogen concentration in deoxygenated water in units of $\mathrm{cm}^{3}$ $\mathrm{H}_{2} \cdot \mathrm{kg}^{-1} \mathrm{H}_{2} \mathrm{O}$ and ppm hydrogen. These results were obtained from Fig. 20 (at $\Delta \mathrm{G}_{\mathrm{T}}=0$ ) and similar curves at other hydrogen concentrations in water.

According to Figs. 20 and 21 , for a given dissolved $\mathrm{H}_{2}$ concentration in water, a higher temperature favors $\mathrm{NiO}$ formation (a $\Delta \mathrm{G}_{\mathrm{T}}$ of $<0$ in Fig. 20), mainly through the $\ln \mathrm{K}$ term in Eq. 3), in contrast to a decrease in thermodynamic stability of oxides in air and other environments as temperature increases (less negative $\Delta \mathrm{G}_{\mathrm{T}}$ ). In Eq. 3, the activity of nickel in Alloy 600 was assumed to be equal to the mole fraction of nickel in the alloy, i.e., 0.72 , which has only a minor effect on the position of the lines in Figs. 20 and 21. For pure nickel, the curves in these figures would be lower by $\approx 10^{\circ} \mathrm{C}$.

For Alloy 600 and other nickel-base alloys, the calculated stability of the $\mathrm{NiO}$ phase (position of the line in Fig. 21) would be influenced by incorporation of chromium into the corrosion-product film, i.e., a more negative $\Delta \mathrm{G}^{\circ}$ for a nickel-chromate film. This would tend to lower the position of the line in Fig. 25 and expand the stability regime for the corrosion- 
product phase. At a fixed temperature, a higher hydrogen concentration in water would be required to prevent the formation of $\mathrm{NiO}$, or alternatively, at a fixed hydrogen concentration in water, a decrease in temperature would produce the same condition. Normal uncertainties in thermodynamic properties and slow oxidation kinetics (Eq. 1) at small, negative $\Delta \mathrm{G}_{\mathrm{T}}$ values near the $\mathrm{Ni} / \mathrm{NiO}$ phase boundary lead to significant uncertainty when predicting whether a corrosion-product phase will actually form on the alloy surface or within a propagating crack at a given temperature and hydrogen concentration in water. Nevertheless, experimental CGR data are being obtained to determine whether these considerations are important in EAC of Alloys 600 and 690 under PWR operating conditions.

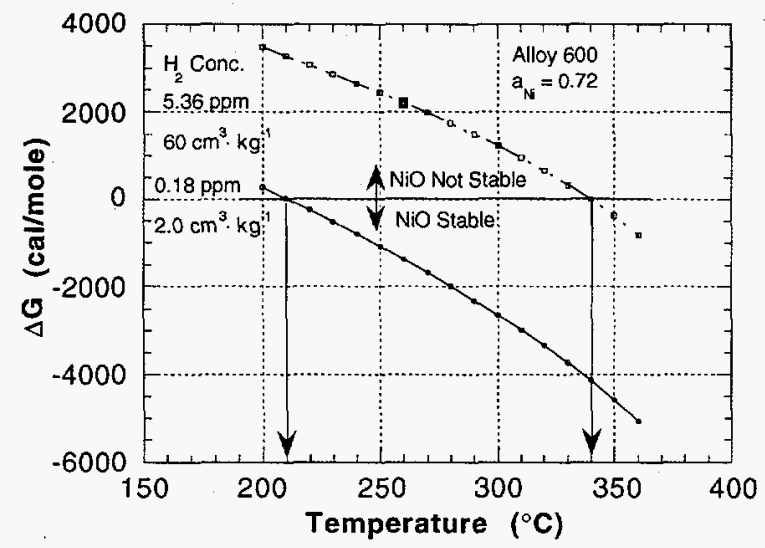

Figure 20.

Temperature dependence of free energy of formation of $\mathrm{NiO}$ on Alloy 600 in water containing 2 and $60 \mathrm{~cm}^{3} \mathrm{H}_{2} \cdot \mathrm{kg}^{-1} \mathrm{H}_{2} \mathrm{O}$. $\mathrm{NiO}$ is not thermodynamically stable at temperatures $<210$ and $<340^{\circ} \mathrm{C}$ in water containing 2 and $60 \mathrm{~cm}^{3} \mathrm{H}_{2} \cdot \mathrm{kg}^{-1} \mathrm{H}_{2} \mathrm{O}$, respectively.

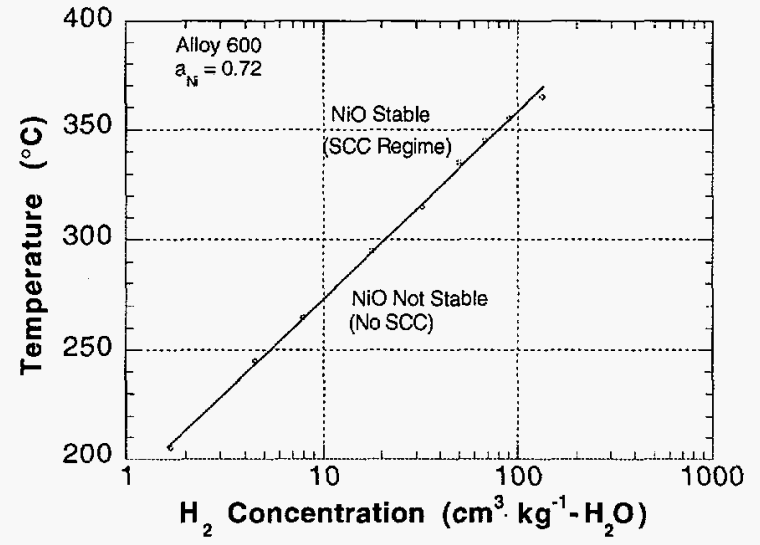

(a)

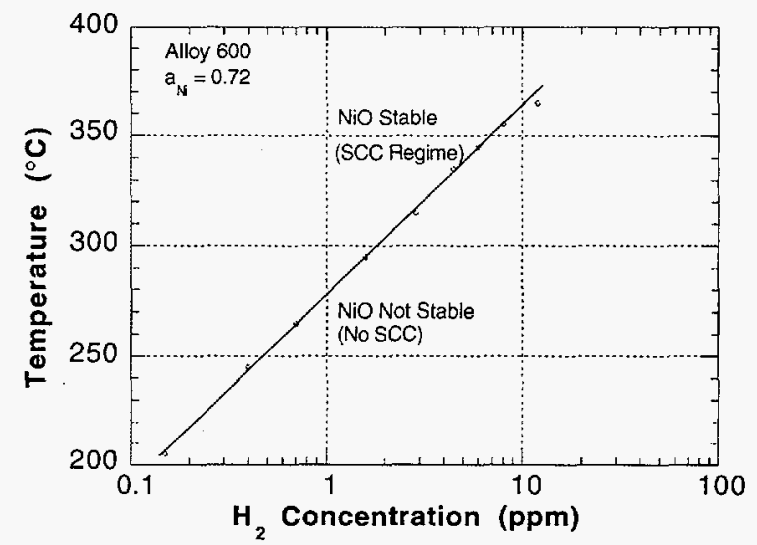

(b)

Figure 21. Calculated thermodynamic stability of NiO on Alloy 600 as a function of temperature and concentration of dissolved hydrogen in water in units of (a) $\mathrm{cm}^{3} \mathrm{H}_{2} \cdot \mathrm{kg}^{-1} \mathrm{H}_{2} \mathrm{O}$ and (b) ppm hydrogen

\subsubsection{Crack Growth Rate in HP Water}

Corrosion-fatigue experiments were conducted on mill-annealed Alloy 600 (Heat No. NX8197) and mill-annealed and thermally treated Alloy 690 (NX8662HG-33) specimens in HP water to investigate the effects temperature and DO and dissolved hydrogen in water on the CGRs of these materials. The grain size (Figs. 1c and 2a) of these specimens is similar and the carbide distribution along grain boundaries of both (Figs. 7 and 10) is continuous, although Alloy 690 contains few intragranular carbides. At $290-320^{\circ} \mathrm{C}$, these heats of Alloy 600 and 
690 have ultimate tensile and yield strengths of $\approx 660$ and 321 and 600 and $235 \mathrm{MPa}$, respectively.

Initial CGR results were obtained at $289^{\circ} \mathrm{C}$ in water that contained $\approx 6-8 \mathrm{ppm}$ and $<5 \mathrm{ppb}$ $\mathrm{DO}$, load ratios of $0.2,0.6$, and 0.9 , and $K_{\max }$ values of $31-33 \mathrm{MPa} \cdot \mathrm{m}^{1 / 2}$ (Tests $1-6$ in Table 8). These stress intensity factors are greater than the threshold value of $\approx 26 \mathrm{MPa} \cdot \mathrm{m}^{1 / 2}$ for EAC of Alloy 600 in oxygenated water (Fig. 16). Crack growth behavior of the two materials is quite similar under the conditions in these experiments. The temperature of the autoclave was increased from 289 to $320^{\circ} \mathrm{C}$ to begin an analogous set of experiments at the higher temperature in water that contained $<5 \mathrm{ppb}$ DO. During this time, the specimens were maintained at a low constant applied load before beginning the cyclic loading tests. Each incremental decrease in applied load (Tests 7-9) was accompanied by an abrupt decrease in electrical resistance of the specimens, which we attribute to closure of the tight crack, followed by a gradual increase in resistance to the inital value because of oxidation of the crack surfaces. Although the DC potential-drop measurements are indicative of crack growth at relatively low stress intensity factors, we believe that the increases in potential are caused by increases in electrical resistivity of the oxide film on crack surfaces near the crack-tip region. Eventually, the resistivities approached values obtained in the last test under cyclic loading conditions.

Two tests were conducted under cyclic loading at load ratios of 0.6 and 0.9 at a stress intensity of $\approx 33 \mathrm{MPa} \cdot \mathrm{m}^{1 / 2}$ (Tests 10 and 11 ). The CGRs at $320^{\circ} \mathrm{C}$ were similar to those at $289^{\circ} \mathrm{C}$ at the two load ratios in water with $<5 \mathrm{ppb}$ DO (Tests 5 and 6). Then, two tests were conducted at $320^{\circ} \mathrm{C}$ in water that contained $\approx 6-7 \mathrm{ppm}$ DO at load ratios of 0.6 and 0.9 (Tests 12 and 13, respectively). The CGRs in these tests are similar to those at $289^{\circ} \mathrm{C}$ (Tests 2 and 3); i.e., CGRs of the Alloy 600 specimen show a small decrease as temperature increases at both $\mathrm{R}$ values. The rates for the Alloy 690 specimen at 289 and $320^{\circ} \mathrm{C}$ are virtually the same at a load ratio of 0.9 .

Three tests were conducted at $320^{\circ} \mathrm{C}$ in water that contained $<5 \mathrm{ppb}$ DO and $\approx 0,2.2$, and $52 \mathrm{~cm}^{3} \cdot \mathrm{kg}^{-1}$ dissolved hydrogen at a load ratio of 0.9 (Tests $14-16$, respectively), and in Test 17 , the load ratio was decreased from 0.9 to 0.6 at the highest hydrogen concentration. At a load ratio of 0.9 , CGRs of both specimens were low $\left(0.5-1.3 \times 10^{-11} \mathrm{~m} \cdot \mathrm{s}^{-1}\right)$ and dissolved hydrogen over the range of $\approx 2-53 \mathrm{~cm}^{3} \cdot \mathrm{kg}^{-1}$ did not have any influence on the rates at a $K_{\max }$ of $\approx 34 \mathrm{MPa} \cdot \mathrm{m}^{1 / 2}$. At a load ratio of $0.6,52 \mathrm{~cm}^{3} \cdot \mathrm{kg}^{-1}$ hydrogen in low-DO water decreased the CGR of the Alloy 600 specimen by a factor of two at $320^{\circ} \mathrm{C}$; however, the rate for the Alloy 690 specimen remained the same (compare Tests 10 and 17 in Table 8). In Tests 10 and 17, the CGRs of Alloy 690 were greater than those of Alloy 600 by factors of $\approx 2.4$ and 5.4 , respectively.

In Test 18 at $320^{\circ} \mathrm{C}$ and a load ratio of 0.6 , the hydrogen concentration was decreased from $\approx 52$ to $4 \mathrm{~cm}^{3} \cdot \mathrm{kg}^{-1}$ and the CGRs of both materials increased. In Test 19 , temperature was decreased from 320 to $289^{\circ} \mathrm{C}$ and the load ratio was increased from 0.6 to 0.9 . These changes produced a significant decrease in the CGRs of the materials. In Tests 20 and 21 , load ratio was decreased from 0.9 to 0.6 and then to 0.2 , respectively. The CGRs in Test 20 increased to values that were somewhat lower than those at $320^{\circ} \mathrm{C}$ for the same loading and water chemistry conditions (i.e., Test 18). CGRs in Tests 22 and 23 at $R$ values of 0.9 and 0.6 in water containing $\approx 54 \mathrm{~cm}^{3} \mathrm{H}_{2} \cdot \mathrm{kg}^{-1} \mathrm{H}_{2} \mathrm{O}$ at $289^{\circ} \mathrm{C}$ were similar in magnitude to those at $320^{\circ} \mathrm{C}$ (Tests 16 and 17 ). 
Table 8. Crack growth results for Alloy 600 and 690 specimens ${ }^{a}$ in $\mathrm{HP}$ water at 289 and $320^{\circ} \mathrm{C}$

\begin{tabular}{|c|c|c|c|c|c|c|c|c|c|c|c|c|c|c|c|}
\hline \multirow{3}{*}{$\begin{array}{l}\text { Test } \\
\text { No. }\end{array}$} & \multirow{3}{*}{$\begin{array}{c}\text { Test } \\
\text { Time, } \\
\text { h }\end{array}$} & \multirow{3}{*}{$\begin{array}{c}\text { Test } \\
\text { Temp. } \\
{ }^{\circ} \mathrm{C}\end{array}$} & \multicolumn{4}{|c|}{ Water Chemistry } & & & \multirow{3}{*}{$\begin{array}{l}\text { Load } \\
\text { Ratio }^{d}\end{array}$} & \multirow{2}{*}{\multicolumn{3}{|c|}{ Alloy 600}} & \multirow{2}{*}{\multicolumn{3}{|c|}{ Allov 690}} \\
\hline & & & \multirow{2}{*}{$\begin{array}{c}\mathrm{H}_{2} \\
\text { Conc., } \\
\mathrm{cm}^{3} \cdot \mathrm{kg}^{-1}\end{array}$} & \multirow{2}{*}{$\begin{array}{c}\mathrm{O}_{2} \\
\text { Conc. }^{c} \\
\text { ppm }\end{array}$} & \multirow{2}{*}{$\begin{array}{l}\text { Cond. } \\
\text { at } 25^{\circ} \mathrm{C} \text {, } \\
\mu \mathrm{S} \cdot \mathrm{cm}^{-1}\end{array}$} & \multirow{2}{*}{$\begin{array}{l}\mathrm{pH} \text { at } \\
25^{\circ} \mathrm{C}\end{array}$} & \multicolumn{2}{|c|}{ Electrode Potential } & & & & & & & \\
\hline & & & & & & & $\begin{array}{l}304 \mathrm{SS} \\
\mathrm{mV} \text { (SHE }\end{array}$ & $\begin{array}{c}\mathrm{Pl} \\
289^{\circ} \mathrm{C}\end{array}$ & & $\begin{array}{r}\mathrm{K}_{\max } \text {. } \\
\mathrm{MPa}\end{array}$ & $\Delta \mathrm{K}, \mathrm{f}$ & $\begin{array}{l}\text { Rate. } \\
10^{-10} \mathrm{~m} \cdot \mathrm{s}^{-1}\end{array}$ & $\begin{array}{r}\mathrm{K}_{\max } \text {. } \\
\mathrm{MPa}\end{array}$ & $\mathrm{n}^{1 / 2}$ & $\begin{array}{l}\text { Rate. } \\
10^{-10} \mathrm{~m} \cdot \mathrm{s}^{-1}\end{array}$ \\
\hline 1 & $\begin{array}{l}45- \\
70\end{array}$ & 289 & - & 5.8 & 0.06 & 6.52 & 170 & 172 & 0.2 & 31.3 & 25.04 & 86.8 & 31.0 & 24.80 & 76.3 \\
\hline 2 & $\begin{array}{l}76- \\
92\end{array}$ & 289 & - & 5.8 & 0.06 & 6.72 & - & - & 0.6 & 31.8 & 12.72 & 28.0 & 31.4 & 12.56 & 24.7 \\
\hline 3 & $\frac{100-}{220}$ & 289 & - & 7.5 & 0.09 & 6.93 & 153 & 152 & 0.9 & 32.2 & 3.22 & 5.2 & 31.6 & 3.16 & 0.82 \\
\hline 4 & $\begin{array}{l}337- \\
347\end{array}$ & 289 & - & $<0.005$ & 0.08 & 6.33 & -267 & -400 & 0.2 & 32.5 & 26.00 & 36.7 & 32.2 & 25.76 & 98.3 \\
\hline 5 & $\begin{array}{l}348- \\
371\end{array}$ & 289 & - & $<0.005$ & 0.08 & 6.33 & -301 & -448 & 0.6 & 32.8 & 13.12 & 10.4 & 32.5 & 13.00 & 17.2 \\
\hline 6 & $\begin{array}{l}373- \\
560\end{array}$ & 289 & - & $<0.005$ & 0.06 & 6.83 & -452 & -461 & 0.9 & 32.9 & 3.29 & 0.08 & 32.6 & 3.26 & 0.06 \\
\hline 7 & $\begin{array}{l}580- \\
720\end{array}$ & 320 & - & $<0.005$ & 0.08 & 6.71 & -488 & -494 & 1.0 & 7.3 & 0 & $-g$ & 7.3 & 0 & $-g$ \\
\hline 8 & $\begin{array}{l}730- \\
910\end{array}$ & 320 & - & $<0.005$ & 0.08 & 6.81 & -510 & -500 & 1.0 & 5.7 & 0 & $-g$ & 5.5 & 0 & $-\mathrm{g}$ \\
\hline 9 & $\begin{array}{l}915- \\
1010\end{array}$ & 320 & - & $<0.005$ & 0.09 & 6.81 & -517 & -506 & 1,0 & 1.1 & 0 & -8 & 1.1 & 0 & $-g$ \\
\hline 10 & $\begin{array}{l}1015- \\
1035\end{array}$ & 320 & - & $<0.005$ & 0.06 & 6.83 & -522 & -509 & 0.6 & 3.3 .2 & 13.28 & 9.98 & 33.0 & 13.20 & 24.0 \\
\hline 11 & $\begin{array}{l}1035- \\
1350\end{array}$ & 320 & - & $<0.005$ & 0.08 & 6.55 & -525 & -513 & 0.9 & 33.3 & 3.33 & 0.28 & 33.1 & 3.31 & 0.02 \\
\hline 12 & $\begin{array}{l}1680- \\
1705\end{array}$ & 320 & - & 5.8 & 0.08 & 6.55 & 168 & 192 & 0.6 & 33.5 & 13.40 & 22.5 & 33.5 & 13.40 & 38.8 \\
\hline 13 & $\begin{array}{l}1705- \\
1895\end{array}$ & 320 & - & 7.0 & 0.08 & 6.31 & 249 & 250 & 0.9 & 33.7 & 3.37 & 1.49 & 33.6 & 3.36 & 0.92 \\
\hline 14 & $\begin{array}{l}1895- \\
2210\end{array}$ & 320 & - & $<0.005$ & 0.08 & 6.57 & -300 & -386 & 0.9 & 33.8 & 3.38 & $=0$ & 33.7 & 3.37 & 0.11 \\
\hline 15 & $\begin{array}{l}2210- \\
2545\end{array}$ & 320 & 2.2 & $<0.001$ & 0.09 & 6.40 & -520 & -516 & 0.9 & 33.9 & 3.38 & 0.13 & 33.8 & 3.38 & 0.05 \\
\hline 16 & $\begin{array}{l}2545- \\
2925\end{array}$ & 320 & 52.1 & $<0.001$ & 0.08 & 6.91 & -610 & -602 & 0.9 & 33.6 & 3.36 & 0.12 & 33.7 & 3.37 & 0.05 \\
\hline 17 & $\begin{array}{l}2925- \\
3020\end{array}$ & 320 & 51.2 & $<0.001$ & 0.09 & 6.80 & -623 & -614 & 0.6 & 33.9 & 13.56 & 4.28 & 35.1 & 14.04 & 23.0 \\
\hline 18 & $\begin{array}{l}4445- \\
4470\end{array}$ & 320 & 3.8 & $<0.001$ & 0.07 & 6.70 & -463 & -454 & 0.6 & 34.5 & 13.80 & 17.0 & 37.5 & 15.00 & 31.2 \\
\hline 19 & $\begin{array}{l}4520- \\
4920\end{array}$ & 289 & 3.2 & $<0.001$ & 0.06 & 6.78 & -534 & -522 & 0.9 & 34.5 & 3.45 & 0.70 & 37.5 & 3.75 & $\approx 0$ \\
\hline 20 & $\begin{array}{l}4920- \\
4949\end{array}$ & 289 & 3.8 & $<0.001$ & 0.06 & 6.66 & -544 & -532 & 0.6 & 34.5 & 13.80 & 3.29 & 37.9 & 15.16 & 23.6 \\
\hline 21 & $\begin{array}{l}4968 \\
4976\end{array}$ & 289 & 4.5 & $<0.001$ & 0.06 & 6.78 & -547 & -535 & 0.2 & 34.8 & 27.84 & 113.70 & 38.6 & 30.88 & 156.6 \\
\hline 22 & $\begin{array}{l}5025- \\
5385\end{array}$ & 289 & 53.7 & $<0.001$ & 0.07 & 6.90 & -599 & -589 & 0.9 & 34.7 & 3.47 & 0.26 & 39.0 & 3.90 & 0.17 \\
\hline 23 & $\begin{array}{l}5385- \\
5405\end{array}$ & 289 & 53.5 & $<0.001$ & 0.07 & 6.90 & -605 & -598 & 0.6 & 34.7 & 13.88 & 0.96 & 39.2 & 15.68 & 16.1 \\
\hline 24 & $\begin{array}{l}5620- \\
5880\end{array}$ & 289 & $1.8 \mathrm{~g}$ & $<0.001$ & 0.06 & 6.93 & -578 & -563 & 1.0 & 5.7 & 0 & 2.06 & 6.7 & 0 & -5 \\
\hline 25 & $\begin{array}{r}5940 \\
6245 \\
\end{array}$ & 289 & $1.2 \mathrm{~g}$ & $<0.001$ & 0.06 & 6.87 & -463 & -451 & 1.0 & 13.6 & 0 & 1.74 & 15.3 & 0 & $-g$ \\
\hline
\end{tabular}

a Compact tension specimens (1TCT) of Alloy 600 (Heat No. NX8197) and Alloy 690 (Heat No. NX8662HG-33). Alloy 600 and 690 specimens (Nos. 197-07 and HG-07, respectively) were tested in the as-received millannealed and mill-annealed plus thermally treated $\left(715^{\circ} \mathrm{C}\right.$ for $\left.5 \mathrm{~h}\right)$ conditions, respectively.

$\mathrm{b}$ Effluent dissolved hydrogen concentration was determined with an Orbisphere hydrogen meter.

c Effluent DO concentration was determined with an Orbisphere oxygen meter or Chemetrics ampules.

d Frequency and rise time of the positive sawtooth waveform were $8 \times 10^{-2} \mathrm{~Hz}$ and $12 \mathrm{~s}$, respectively.

e Stress intensity $K_{\max }$ values at the end of the time period.

$\mathrm{f}_{\Delta \mathrm{K}}=\mathrm{K}_{\max }(1-\mathrm{R})$, where load ratio $\mathrm{R}=\mathrm{K}_{\min } / \mathrm{K}_{\max }$.

$\mathrm{g}$ Hold periods a constant load at lower stress intensity values.

h Corrosion-product hydrogen; no hydrogen was added to the feedwater.

Two tests were conducted at $289^{\circ} \mathrm{C}$ under constant load (Tests 24 and 25) at low stress intensity factors, in which no hydrogen was added to the feedwater. The DC potential-drop response of the specimens was similar to that in Tests 7-9. When load was decreased in Test 24 and then increased in Test 25 , the resistivitity of both specimens first decreased and then increased abruptly, followed by a gradual increase to the values obtained at the end of Test 23 . This behavior tends to confirm the hypothesis that DC potential-drop measurements are strongly influenced by morphology and degree of oxidation of crack surfaces in constant load tests if $\mathrm{K}_{\max }$ decreases, in contrast to actual increases in crack length during cyclic loading with increasing $K_{\max }$. 
The dependence of the CGRs of Alloy 600 and 690 specimens at $320^{\circ} \mathrm{C}$ on DO concentration in HP water and on the ECP of a platinum electrode (at $289^{\circ} \mathrm{C}$ ) is shown in Fig. 22. At a load ratio of 0.6 (Figs. 22a and b), CGRs are not dependent on either DO or ECP, which is indicative of a strong contribution of cyclic loading to the rates. At a higher load ratio of 0.9, CGRs decrease as DO concentration and ECP decrease, Figs. 22c and d, respectively. Figure 23 shows similar results at $289^{\circ} \mathrm{C}$ at load ratios of $0.2,0.6$, and 0.9 . At a high load ratio of 0.9 , CGRs exhibit a 1/4-power dependence on DO concentration, which has been observed previously in slow-strain-rate tensile tests on sensitized Type 304 SSs.11,12 The dependence of the CGRs on $\mathrm{K}_{\max }$ at load ratios of $0.2-0.9$ in deoxygenated water $(<5 \mathrm{ppb})$ and in water with 6-8 ppm DO is shown in Fig. 24.

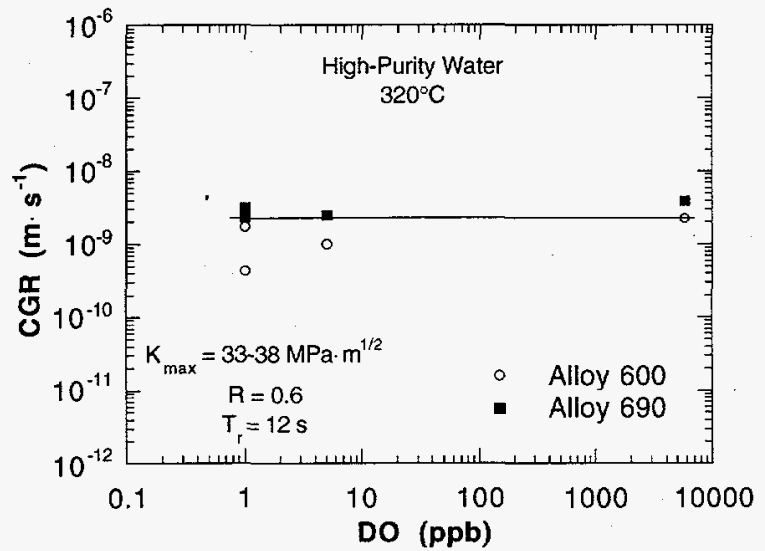

(a)

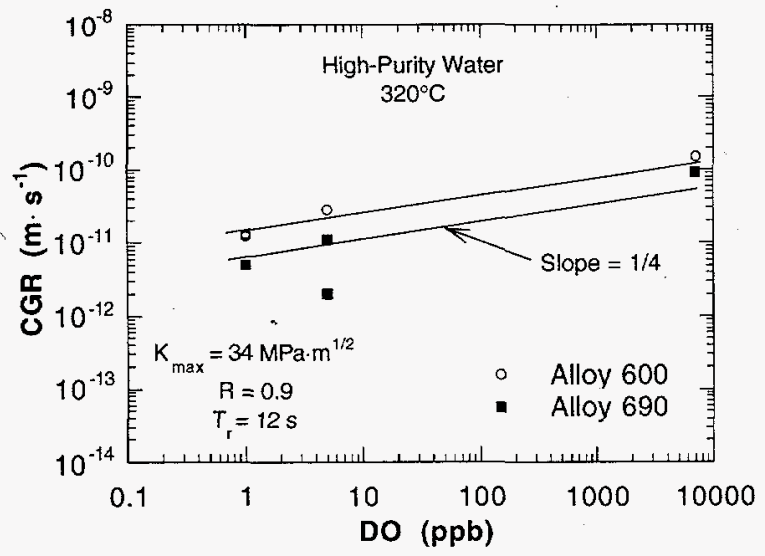

(c)

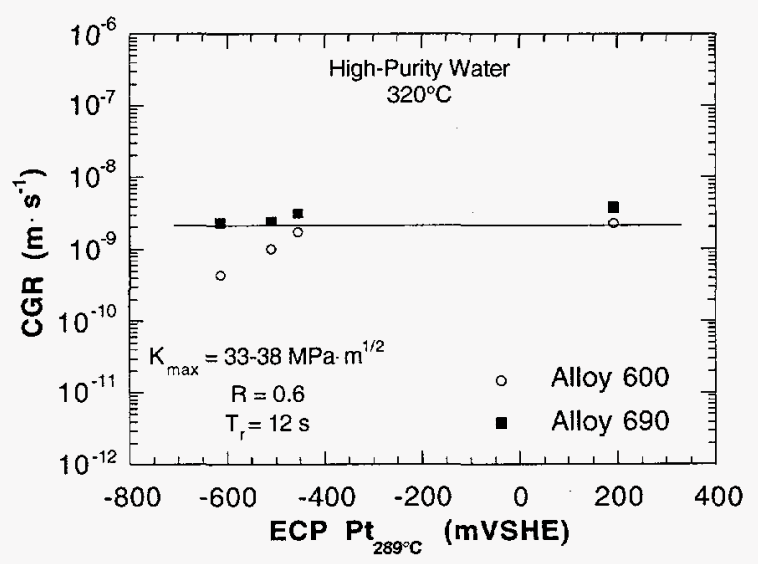

(b)

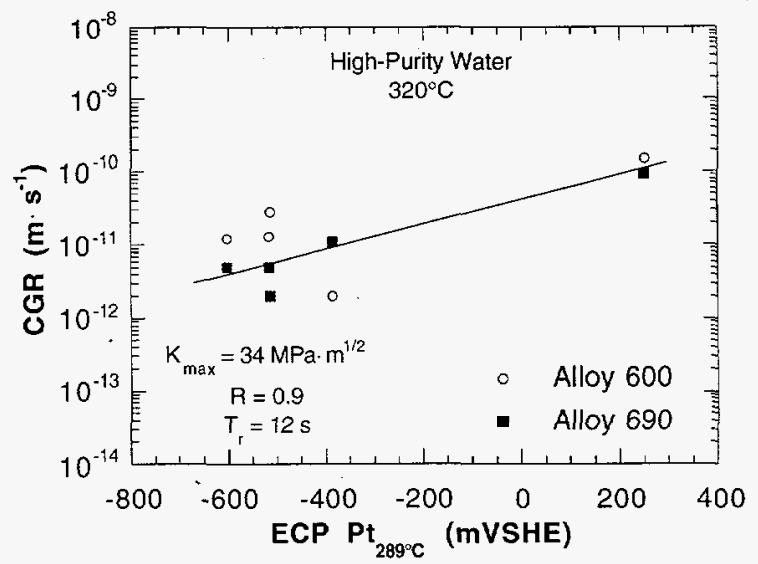

(d)

Figure 22. Dependence of CGRs of Alloy 600 and 690 specimens in HP water at $320^{\circ} \mathrm{C}$ on DO concentration and ECP of Pt electrode at $289^{\circ} \mathrm{C}$ at load ratios of 0.6 ( $a$ and $b$ ) and 0.9 ( $c$ and $d)$, respectively

Lines that depict the predicted dependence for austenitic SSs in air from Section XI of the ASME Code at the various $\mathrm{R}$ values are also shown in Fig. 24. In all cases, the CGRs of both alloys lie near or below the air curve for austenitic SSs. Crack growth experiments on these alloys in air at 289 and $320^{\circ} \mathrm{C}$ are planned to determine whether the rates differ significantly from those of austenitic SSs and to provide baseline data for these and subsequent tests in simulated LWR environments. 


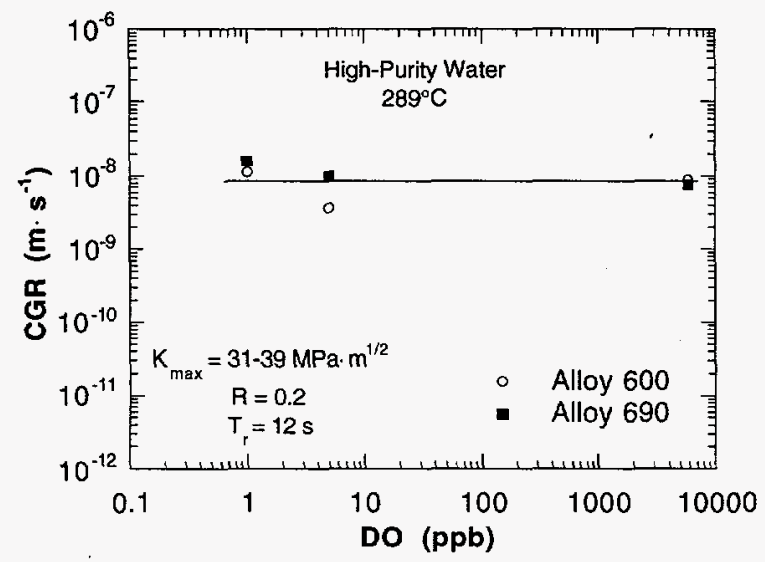

(a)

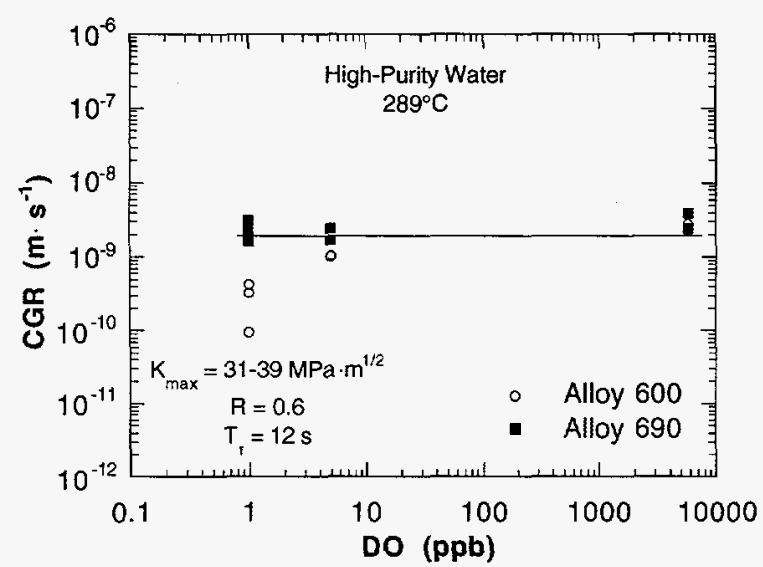

(c)

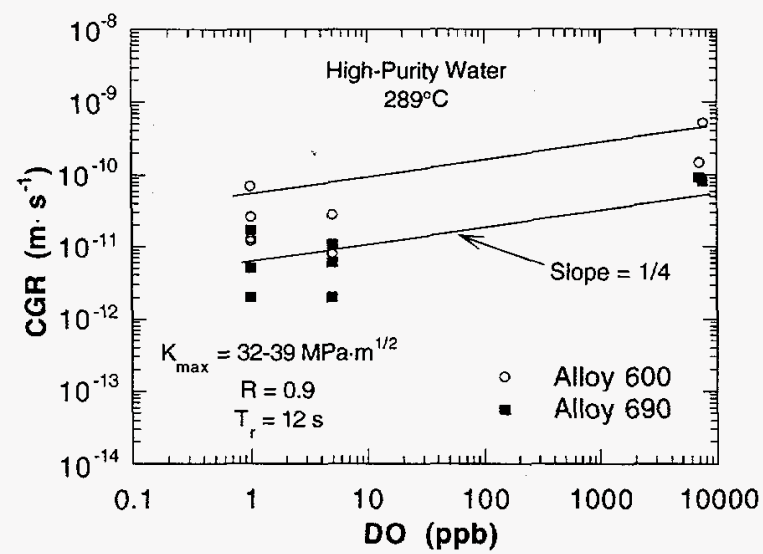

(e)

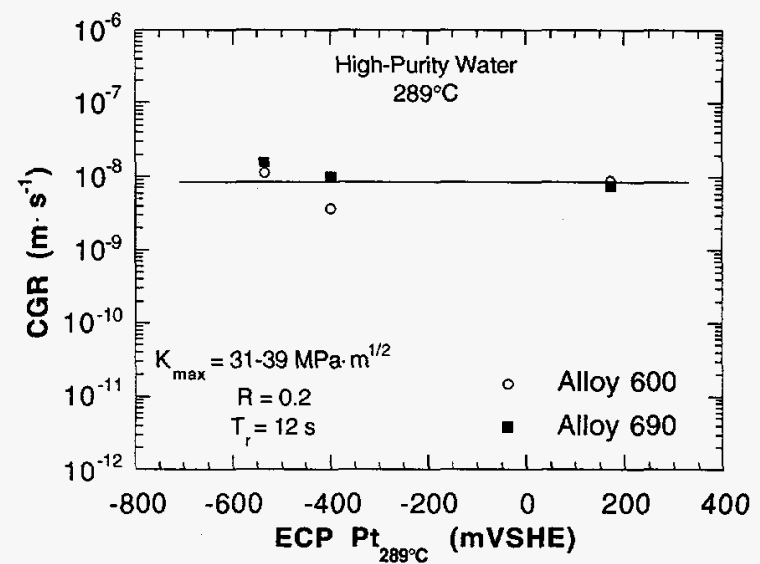

(b)

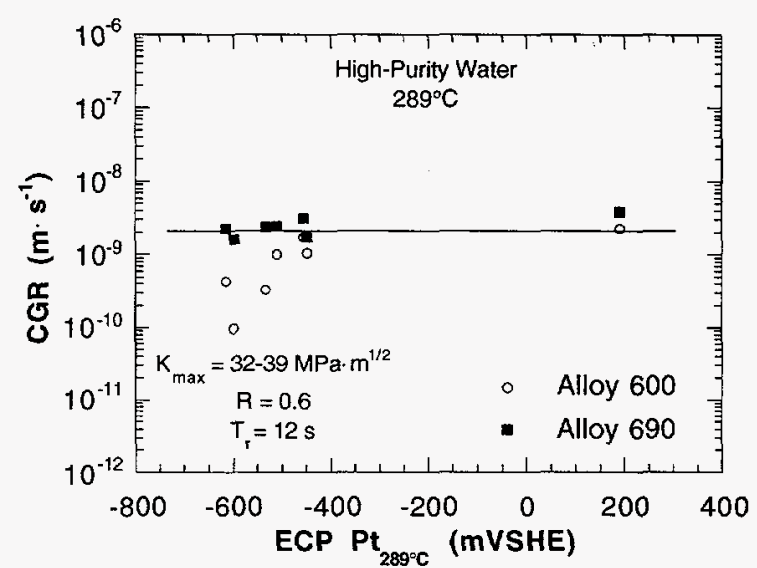

(d)

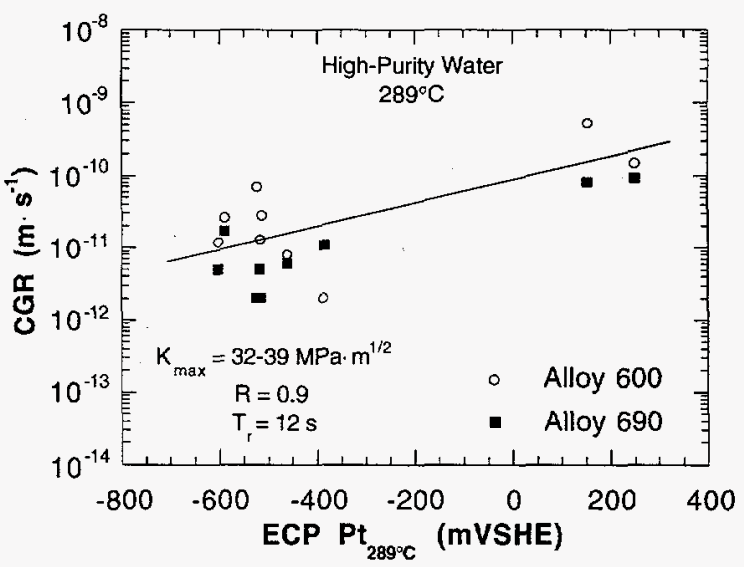

(f)

Figure 23. Dependence of CGRs of Alloy 600 and 690 specimens in HP water at $289^{\circ} \mathrm{C}$ on $D O$ concentration and ECP of Pt electrode at $289^{\circ} \mathrm{C}$ at load ratios of 0.2 ( $a$ and $b$ ), $0.6(c$ and $d)$, and 0.9 ( $e$ and $f$ ), respectively

Corrosion-fatigue data for the alloys at 289 and $320^{\circ} \mathrm{C}$ are plotted vs. predicted CGRs for austenitic SSs in air from the ASME Code (Fig. 25a) and vs. rates in water predicted by the ANL model, 5 which has been modified to account for a 1/4-power dependence on DO 


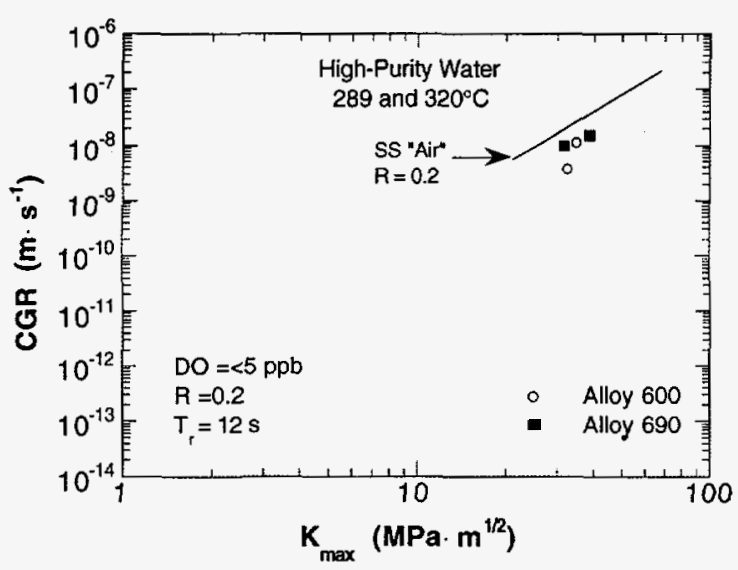

(a)

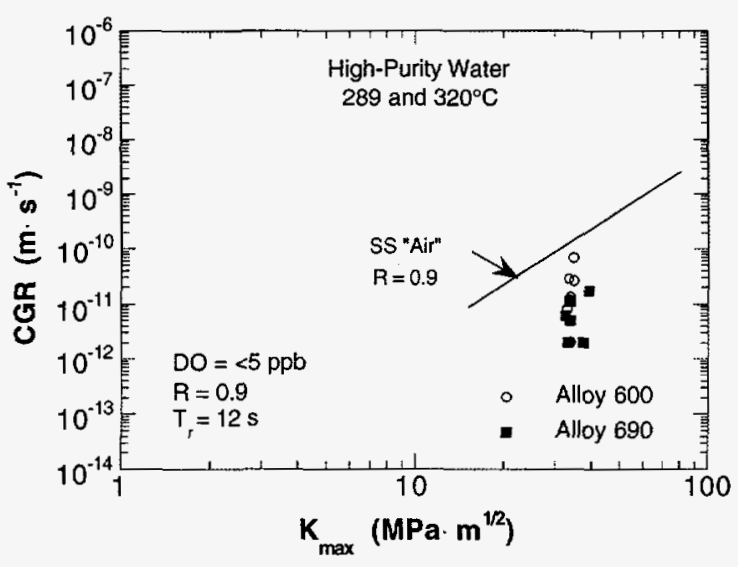

(c)

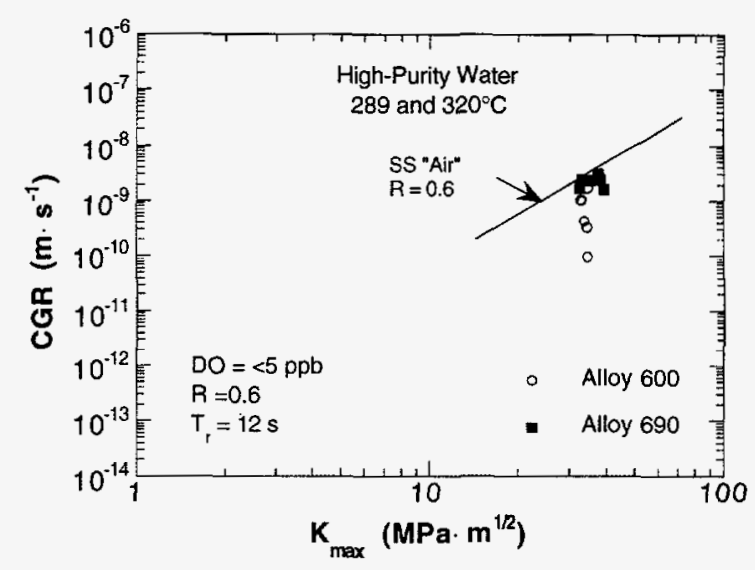

(b)

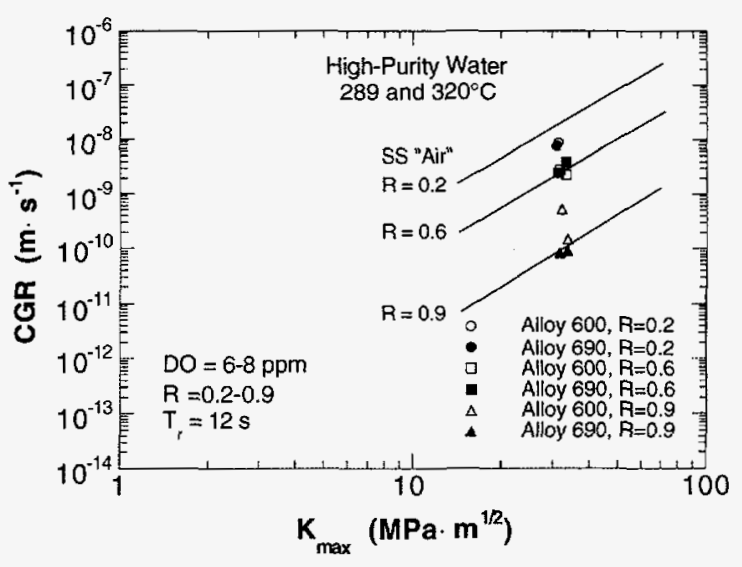

(d)

Figure 24. Dependence of CGRs of Alloy 600 and 690 specimens at 289 and $320^{\circ} \mathrm{C}$ on maximum stress intensity ( $K_{\max }$ in HP deoxygenated water at load ratios of (a) 0.2 , (b) 0.6 , and (c) 0.9 , and (d) in oxygenated HP water at load ratios of 0.2 , 0.6, and 0.9. Lines indicate dependence of CGRs of austenitic SSs in air on $K_{\text {max }}$ predicted by ASME Code.

concentration in water of the environmnental contribution a env to crack growth (Section 3.5). Both figures indicate that the experimental data lie near or below predicted values for austenitic SSs in air or water, respectively, for the loading conditions and DO concentrations employed in these experiments. Crack growth information for nickel-base alloys in air will be sought to obtain a comparison similar to that in Fig. 25. In particular, information on CGRs of the materials in air at rates $<10^{-10} \mathrm{~m} \cdot \mathrm{s}^{-1}$ are required to determine whether they also deviate from the ASME-predicted air line.

\subsection{CGRs of Mill-Annealed Alloy 600 and Thermally Treated Alloy 690 in Simulated PWR Water at 289 and $320^{\circ} \mathrm{C}$}

The influence of dissolved hydrogen in simulated PWR water on CGRs of Alloy 600 and 690 specimens from the same heats of material was determined in another series of experiments at 289 and $320^{\circ} \mathrm{C}$. The water contained $450 \mathrm{ppm}$ boron, $2.25 \mathrm{ppm}$ lithium, $<2 \mathrm{ppb}$ DO, and $\approx 3-58 \mathrm{~cm}^{3} \mathrm{H}_{2} \cdot \mathrm{kg}^{-1} \mathrm{H}_{2} \mathrm{O}$. Because of problems encountered with the DC 


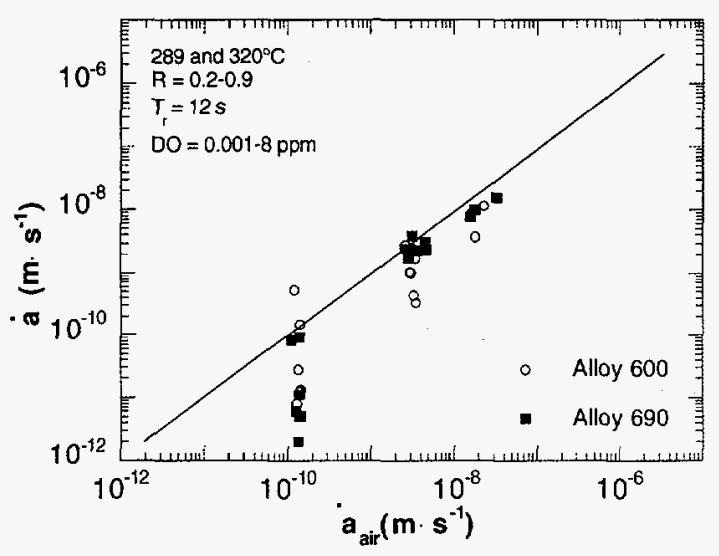

(a)

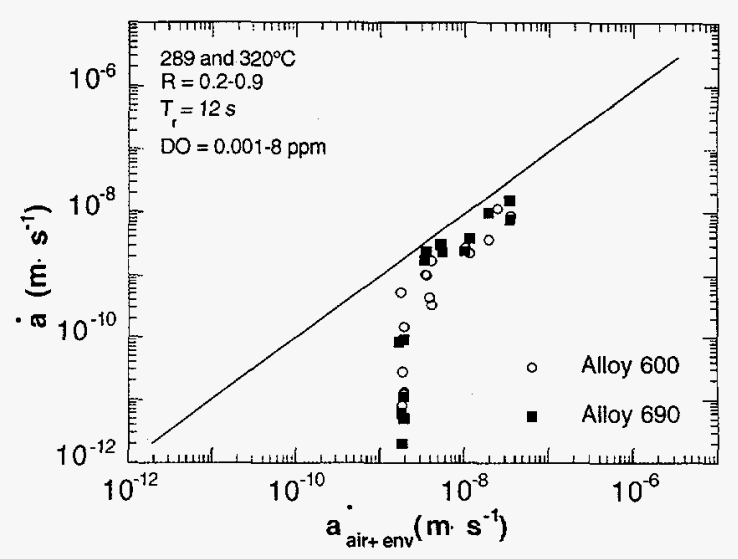

(b)

Figure 25. Corrosion fatigue data for Alloy 600 and 690 specimens in HP water at 289 and $320^{\circ} \mathrm{C}$ us. (a) CGRs for SSs in air, predicted by ASME Code, and (b) CGRs for SSs in water predicted by ANL model, both under same loading conditions as in experiments. Lines represent identical CGRs for these alloys in test environments and for SSs in (a) air and (b) water.

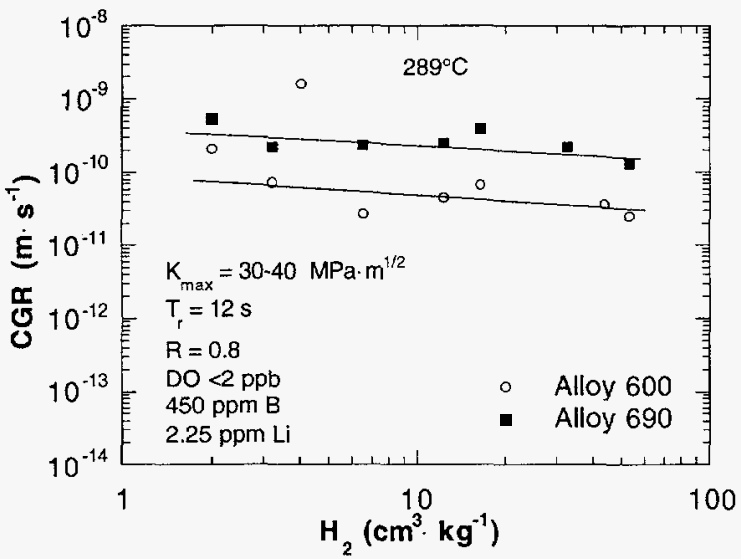

(a)

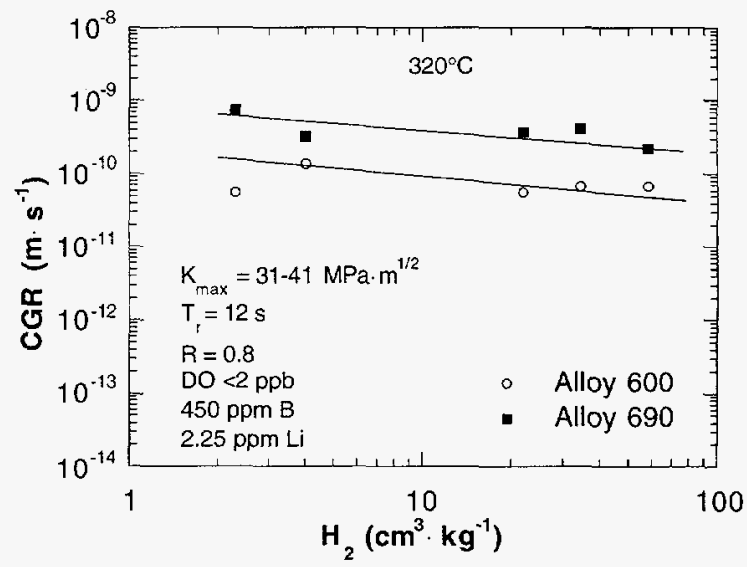

(b)

Figure 26. Dependence of CGRs of Alloy 600 and 690 specimens at (a) 289 and (b) $320^{\circ} \mathrm{C}$ on concentration of dissolved hydrogen in simulated PWR water at load ratio of 0.8

potential-drop technique, crack length was determined by the compliance method with the use of MTS clip gages. Tests were conducted at a load ratio of 0.8 and $K_{\max }$ in the range $\approx 30-39 \mathrm{MPa} \cdot \mathrm{m}^{1 / 2}$. The results are given in Table 9 and plotted in Fig. 26 .

CGRs decreased slightly as dissolved hydrogen concentration increased from 3 to $58 \mathrm{~cm}^{3} \cdot \mathrm{kg}^{-1}$. The Alloy 690 specimen exhibited a higher CGR by a factor of $\approx 3$ than Alloy 600 under these water chemistry conditions at both temperatures. A somewhat larger decrease in the CGRs was expected, based on a predicted change in the thermodynamic stability of NiO corrosion product on the alloys as the concentration of dissolved hydrogen in the water increased or as the temperature decreased in these experiments. More experimental CGR data are required to deduce whether these considerations are important in EAC of Alloy 600 and other nickel-base alloys under PWR operating conditions. 
Table 9. Crack growth results for Alloy 600 and 690 specimens ${ }^{a}$ in simulated PWR water at 289 and $320^{\circ} \mathrm{C}$

\begin{tabular}{|c|c|c|c|c|c|c|c|c|c|c|c|c|c|c|c|c|c|}
\hline \multirow{3}{*}{$\begin{array}{l}\text { Test } \\
\text { No. }\end{array}$} & \multirow{3}{*}{$\begin{array}{c}\text { Test } \\
\text { Time, } \\
\text { h }\end{array}$} & \multirow{3}{*}{$\begin{array}{c}\text { Test } \\
\text { Temp, } \\
{ }^{\circ} \mathrm{C}\end{array}$} & \multicolumn{6}{|c|}{ Water Chemistry } & \multirow{3}{*}{$\begin{array}{l}\text { Electrode } \\
304 \mathrm{SS} \\
\mathrm{mV}(\mathrm{SHE})\end{array}$} & \multirow{3}{*}{$\begin{array}{l}\text { Potential } \\
\text { Alloy } 600 \\
\text { at } 289^{\circ} \mathrm{C}\end{array}$} & \multirow{3}{*}{$\begin{array}{l}\text { Load } \\
\text { Ratio }^{\mathrm{e}}\end{array}$} & \multirow{2}{*}{\multicolumn{3}{|c|}{ Alloy 600}} & \multirow{2}{*}{\multicolumn{3}{|c|}{ Alloy 690}} \\
\hline & & & \multirow{2}{*}{$\begin{array}{c}\text { B } \\
\text { Conc., } b \\
\text { ppm }\end{array}$} & \multirow{2}{*}{$\begin{array}{c}\mathrm{Li} \\
\text { Conc.,b } \\
\text { ppm }\end{array}$} & \multirow{2}{*}{$\begin{array}{c}\mathrm{H}_{2} \\
\text { Conc., } \mathrm{c} \\
\mathrm{cm}^{3} \cdot \mathrm{kg}^{-1}\end{array}$} & \multirow{2}{*}{$\begin{array}{c}\mathrm{O}_{2} \\
\text { Conc., } d \\
\mathrm{ppb}\end{array}$} & \multirow{2}{*}{$\begin{array}{c}\text { Cond. } \\
\text { at } 25^{\circ} \mathrm{C} \text {, } \\
\mu \mathrm{S} \cdot \mathrm{cm}^{-1}\end{array}$} & \multirow{2}{*}{$\begin{array}{l}\mathrm{pH} \text { at } \\
25^{\circ} \mathrm{C}\end{array}$} & & & & & & & & & \\
\hline & & & & & & & & & & & & $\begin{array}{l}\mathrm{K}_{\max } \mathrm{f}, \\
\mathrm{MPa} \cdot \mathrm{n}\end{array}$ & $\begin{array}{l}\Delta \mathrm{K}, \mathrm{g} \\
1 / 2\end{array}$ & $\begin{array}{c}\text { Rate, } \\
10^{-10} \mathrm{~m} \cdot \mathrm{s}^{-1}\end{array}$ & $\begin{array}{l}\mathrm{K}_{\max } \mathrm{f}, \\
\text { MPa. m }\end{array}$ & $\begin{array}{l}\Delta \mathrm{K}, \mathrm{g} \\
1 / 2\end{array}$ & $\begin{array}{c}\text { Rate, } \\
10^{-10} \mathrm{~m} \cdot \mathrm{s}^{-1}\end{array}$ \\
\hline 1 & $\begin{array}{c}0 \\
540\end{array}$ & 289 & 450 & 2.25 & 53.0 & $<2$ & 26 & 7.23 & -798 & -805 & 0.8 & 30.3 & 6.06 & 0.25 & 30.7 & 6.14 & 1.29 \\
\hline 2 & $\begin{array}{c}540- \\
1020\end{array}$ & 320 & 450 & 2.25 & 58.0 & $<2$ & 31 & 7.32 & -805 & -809 & 0.8 & 30.6 & 6.12 & 0.68 & 31.3 & 6.26 & 2.19 \\
\hline 3 & $\begin{array}{l}1020- \\
1550\end{array}$ & 320 & 450 & 2.25 & 4.0 & $<2$ & 35 & 7.32 & -760 & -757 & 0.8 & 31.0 & 6.20 & 1.35 & 32.4 & 6.48 & 3.25 \\
\hline 4 & $\begin{array}{l}1550- \\
2010\end{array}$ & 289 & 450 & 2.25 & 3.2 & $<2$ & 36 & 7.42 & -745 & -741 & 0.8 & 31.2 & 6.24 & 0.73 & 33.0 & 6.60 & 2.20 \\
\hline 5 & $\begin{array}{l}2010 \\
2550\end{array}$ & 289 & 450 & 2.25 & 6.5 & $<2$ & 38 & 7.39 & -755 & -758 & 0.8 & 31.4 & 6.28 & 0.27 & 33.9 & 6.78 & 2.30 \\
\hline 6 & $\begin{array}{l}2550- \\
2790\end{array}$ & 289 & 450 & 2.25 & 12.3 & $<2$ & 41 & 7.27 & -777 & -780 & 0.8 & 31.4 & 6.28 & 0.45 & 34.3 & 6.86 & 2.51 \\
\hline 7 & $\begin{array}{l}2790- \\
3270\end{array}$ & 289 & 450 & 2.25 & 16.4 & $<2$ & 39 & 7.29 & -771 & -773 & 0.8 & 31.8 & 6.36 & 0.68 & 35.7 & 7.14 & 3.93 \\
\hline 8 & $\begin{array}{l}3275- \\
3730\end{array}$ & 320 & 450 & 2.25 & 22.0 & $<2$ & 40 & 7.28 & -732 & -737 & 0.8 & 31.9 & 6.38 & 0.56 & 36.9 & 7.38 & 3.73 \\
\hline 9 & $\begin{array}{l}3732- \\
4086\end{array}$ & 320 & 450 & 2.25 & 34.4 & $<2$ & 38 & 7.28 & -785 & -791 & 0.8 & 32.1 & 6.42 & 0.68 & 38.0 & 7.60 & 4.19 \\
\hline 10 & $\begin{array}{l}4088- \\
4430\end{array}$ & 289 & 450 & 2.25 & 32.7 & $<2$ & 38 & 7.27 & -784 & -794 & 0.8 & 32.1 & 6.42 & $\approx 0$ & 38.6 & 7.72 & 2.18 \\
\hline 11 & $\begin{array}{l}4760- \\
5070\end{array}$ & 289 & 450 & 2.25 & $2.0 \mathrm{~h}$ & $<2$ & 37 & 7.26 & -745 & -720 & 0.8 & 32.4 & 6.48 & 2.09 & 39.9 & 7.98 & 5.39 \\
\hline 12 & $\begin{array}{l}5070- \\
5310 \\
\end{array}$ & 320 & 450 & 2.25 & $2.3^{h}$ & $<2$ & 36 & 7.26 & -739 & -736 & 0.8 & 32.7 & 6.54 & 0.56 & 41.4 & 8.28 & 7.51 \\
\hline
\end{tabular}

a Compact tension specimens (1TCT) of Alloy 600 (Heat No. NX8197) and Alloy 690 (Heat No. NX8662HG-33). The Alloy 600 and 690 specimens (Nos. 197-

09 and HG-09, respectively) were tested in the as-received mill-annealed and annealed plus thermally treated ( $715^{\circ} \mathrm{C}$ for 5 h) conditions, respectively.

$\mathrm{b}$ Boron and lithium were added to the feedwater as $\mathrm{H}_{3} \mathrm{BO}_{3}$ and $\mathrm{LiOH}$.

c Effluent dissolved hydrogen concentration was determined with an Orbisphere hydrogen meter.

$\mathrm{d}$ Effluent $\mathrm{DO}$ concentration was $<2 \mathrm{ppb} ; \approx 750 \mathrm{ppb}$ hydrazine was added to deoxygenated feedwater to scavenge residual DO, which was measured

with Chemetrics ampules for the "ultra low range."

e Frequency and rise time of the positive sawtooth waveform were $8 \times 10^{-2} \mathrm{~Hz}$ and $12 \mathrm{~s}$, respectively.

${ }^{f}$ Stress intensity $K_{\max }$ values at the end of the time period.

$\mathrm{g} \Delta \mathrm{K}=\mathrm{K}_{\max }(1-\mathrm{R})$, where load ratio $\mathrm{R}=\mathrm{K}_{\min } / \mathrm{K}_{\max }$

$\mathrm{h}$ Corrosion-product hydrogen; hydrogen was not added to the feedwater. 


\subsection{Dependence on $\triangle K$ of CGRs of Mill-Annealed Alloy 600 and Thermally Treated Alloy 690 in HP and Simulated PWR Water at 289 and $320^{\circ} \mathrm{C}$}

Exploration of the dependence of CGRs of mill-annealed Alloy 600 and thermally treated Alloy 690 specimens at 289 and $320^{\circ} \mathrm{C}$ on $\Delta \mathrm{K}$ can be based on tests performed in $\mathrm{HP}$ and simulated PWR water (Tables 8 and 9, respectively) at several load ratios. The results were compared with predictions of the ANL model for crack growth of austenitic SSs in water. 5 Briefly, the CGR $\dot{a}_{\text {super }}$ in an aqueous environment is written as a superposition of a term that represents the contribution of SCC under constant load $\dot{a}_{S C C}$; a corrosion-fatigue term a env, representing the additional CGR under cyclic loading due to the environment; and a mechanical fatigue term $\dot{a}_{a i r}$, representing fatigue-crack growth in air,

$$
\dot{\mathrm{a}}_{\text {super }}=\dot{\mathrm{a}}_{\mathrm{SCC}}+\dot{\mathrm{a}}_{\mathrm{env}}+\dot{\mathrm{a}}_{\mathrm{air}}
$$

The SCC term was obtained from a correlation given in U.S. Nuclear Regulatory Commission (NRC) Report NUREG-0313, Rev. 2, January 1988. The correlation was based largely on data in water that contained $8 \mathrm{ppm}$ DO at impurity levels typically higher than those found in currently operating plants. To account for additional data at $200 \mathrm{ppb}$ DO and more representative impurity levels, the CGR is taken as one-third that given in NUREG-0313:

$$
\begin{array}{ll}
\dot{\mathrm{a}}_{\mathrm{SCC}}=2.1 \times 10^{-13} \mathrm{~K}^{2.161}\left(\mathrm{~m} \cdot \mathrm{s}^{-1}\right) & 8 \mathrm{ppm} \mathrm{DO} \\
\dot{\mathrm{a}}_{\mathrm{SCC}}=7.0 \times 10^{-14} \mathrm{~K}^{2.161}\left(\mathrm{~m} \cdot \mathrm{s}^{-1}\right) & 200 \mathrm{ppb} \mathrm{DO},
\end{array}
$$

where $\mathrm{K}$ is the stress intensity factor in $\mathrm{MPa} \cdot \mathrm{m}^{1 / 2}$. The contribution from SCC is assumed to be negligible for deoxygenated HP water and for PWR primary-water-chemistry conditions; consequently, the CGR is given by

$$
\dot{\mathrm{a}}=\dot{\mathrm{a}}_{\mathrm{env}}+\dot{\mathrm{a}}_{\mathrm{air}} \text {. }
$$

The air term, based on the work of James and Jones, ${ }^{13}$ is given by the current ASME Code Section XI correlation at $288^{\circ} \mathrm{C}$ as

$$
\begin{array}{rlrl}
\dot{\mathrm{a}}_{\text {air }} & =3.43 \times 10^{-12} \mathrm{~S}(\mathrm{R}) \Delta \mathrm{K}^{3.3} / \mathrm{T}_{\mathrm{R}} \\
\mathrm{S}(\mathrm{R}) & =1+1.8 \mathrm{R} & & \mathrm{R} \leq 0.8 \\
& =-43.35+57.97 \mathrm{R} & \mathrm{R}>0.8
\end{array}
$$

where $T_{R}$ is the rise time in $s$ of the loading wave form, $R$ is the load ratio $\left(K_{\min } / K_{\max }\right)$, and $\Delta \mathrm{K}$ is $\mathrm{K}_{\max }-\mathrm{K}_{\min }$. Following Shoji ${ }^{14}$ and Gilman et al., ${ }^{15}$ the corrosion-fatigue term is assumed to be related to $\dot{\mathrm{a}}_{\mathrm{air}}$ through a power law

$$
\dot{\mathrm{a}}_{\mathrm{env}}=\mathrm{A} \dot{\mathrm{a}}_{\text {air }}^{\mathrm{m}} \text {. }
$$

The values of the coefficient $\mathrm{A}$ and the exponent $\mathrm{m}$ for water with $200 \mathrm{ppb} \mathrm{DO}$ at $288^{\circ} \mathrm{C}$ were obtained by an empirical power-law-curve fit to the existing data for austenitic SSs at $\mathrm{R}<0.9$, where cyclic loading dominates and the stress corrosion term in the superposition model (Eq. 5) can be ignored. The values are

$$
\begin{aligned}
& \mathrm{A}=4.5 \times 10^{-5} \\
& \mathrm{~m}=0.5
\end{aligned}
$$

for CGRs in $\mathrm{m} \cdot \mathrm{s}^{-1}$ and $\mathrm{K}$ in $\mathrm{MPa} \cdot \mathrm{m}^{1 / 2}$. In water that contains $8 \mathrm{ppm} \mathrm{DO}$ at $288^{\circ} \mathrm{C}$, an empirical power-law-curve fit to the available data gives 


$$
\begin{aligned}
& \mathrm{A}=1.5 \times 10^{-4} \\
& \mathrm{~m}=0.5 .
\end{aligned}
$$

As was mentioned previously, the dependence of CGRs of austenitic SSs on DO concentration $\left[\mathrm{O}_{2}\right]$ follows an $\approx\left[\mathrm{O}_{2}\right]^{1 / 4}$ relationship over this range of oxygen concentrations. 11,12 The results for Alloys 600 and 690 in Figs. 22c and 23e also exhibit this dependence on DO. To compare model predictions with CGRs in water that contains low DO levels, the values of $\mathrm{A}$ at $200 \mathrm{ppb}$ and $8 \mathrm{ppm}$ were fit to a power-law relationship and the constant $A$ in Eq. 9 is given by the relationship

$$
\mathrm{A}=1.08 \times 10^{-5}(\mathrm{DO})^{0.287} \text {. }
$$

From Eq. 8, it is evident that $\dot{a}_{\text {air }}$ exhibits a complex dependence on R; therefore, the predicted dependence of the crack growth rate a on $\Delta \mathrm{K}$ can be obtained from Eqs. 7-9, and 12 at differing values of R. Figure 27 shows the predicted dependence of $\dot{a}$ on $\Delta \mathrm{K}$ in $288^{\circ} \mathrm{C}$ water that contains $1 \mathrm{ppb} D O$ at several $R$ values between 0.2 and 0.95 , a rise time of $12 \mathrm{~s}$, and $K_{\max }$ between 3 and $100 \mathrm{MPa} \cdot \mathrm{m}^{1 / 2}$. At $\mathrm{R}$ values $\leq 0.8$, the curves do not differ significantly, whereas, at higher $\mathrm{R}$ values, the range of $\dot{a}$ is wider for a given $\Delta K$.

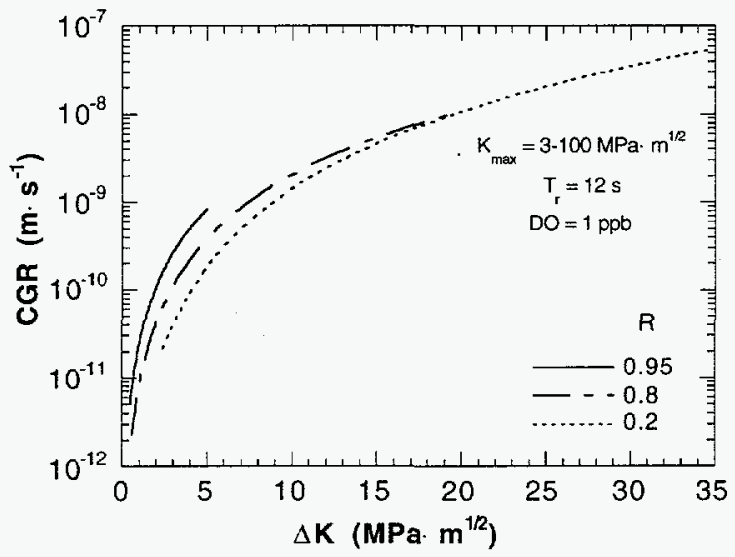

Figure 27.

Dependence of CGR at $288^{\circ} \mathrm{C}$ on $\triangle K$ for $R$ of $0.2,0.8$, and 0.95 in water containing $1 \mathrm{ppb}$ $D O$, predicted by ANL model

The relative contribution of the $\dot{\mathrm{a}}_{\text {air }}$ and $\dot{\mathrm{a}}$ env terms in the model at several $\mathrm{R}$ values between 0.2 and 0.95 is shown in Fig. 28. At $\Delta \mathrm{K}$ values $\approx>5 \mathrm{MPa} \cdot \mathrm{m}^{1 / 2}$, mechanically induced crack growth, i.e., $\dot{\mathrm{a}}_{\text {air }}$, is the major contributor to the rate, whereas, at values $\approx<5 \mathrm{MPa} \cdot \mathrm{m}^{1 / 2}$, the $\dot{a}$ env term is similar in magnitude to $\dot{a}_{\text {air }}$. At low $\Delta \mathrm{K}$, i.e., $3-5 \mathrm{MPa} \cdot \mathrm{m}^{1 / 2}$, $\dot{\mathrm{a}}_{\text {air }}$ and $\dot{\mathrm{a}}$ env are $\approx 1 \times 10^{-10} \mathrm{~m} \cdot \mathrm{s}^{-1}$ over the entire range of $\mathrm{R}$. Thus, to explore EAC of these materials, experiments should be conducted at low $\Delta \mathrm{K}$ and at $\mathrm{K}_{\mathrm{max}}>\mathrm{K}_{\text {Threshold, where significant }}$ enhancement in the rates should occur.

Experimental CGR data for Alloys 600 and 690 from Tables 8 and 9 can be compared with model predictions. Figures 29 and 30 show the dependence of CGRs of mill-annealed Alloy 600 and thermally treated Alloy 690 specimens at 289 and $320^{\circ} \mathrm{C}$ on $\Delta \mathrm{K}$ at constant load ratios in deoxygenated HP and simulated PWR water, respectively. The experiments were not conducted by adjusting (increasing) $\Delta K$ at constant $R$ values, rather, the data were obtained by adjusting $\mathrm{R}$ at a given $\mathrm{K}_{\max }$, in which $\mathrm{K}_{\max }$ increases slowly as crack length increases during the course of the experiments. The data in both environments are consistent with the trend lines depicted in the figures; however, in some instances, experimental CGRs for Alloy 690 at high $R(0.9)$ lie significantly below the trend lines. The current results on Alloy 690 were obtained from a heat that has a relatively low yield stress when compared with that of Alloy 


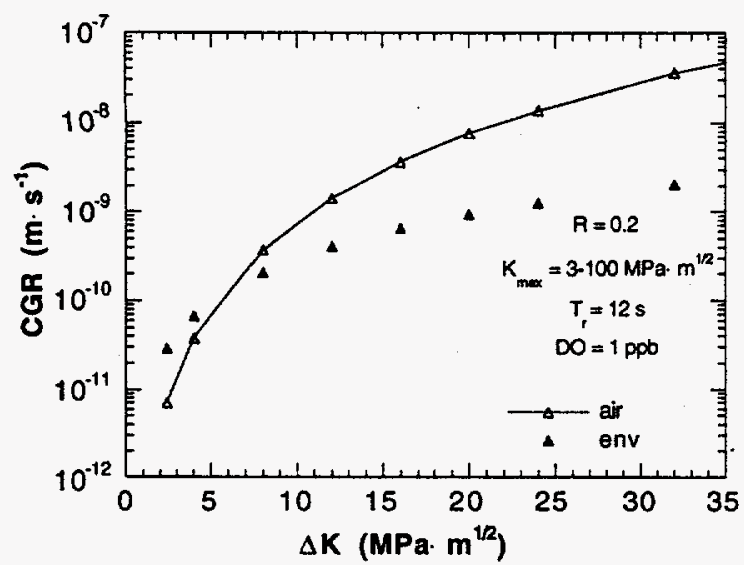

(a)

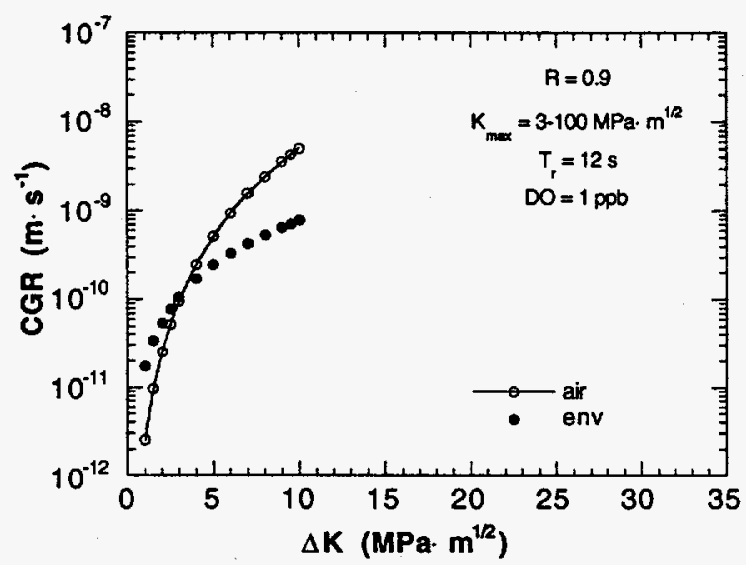

(c)

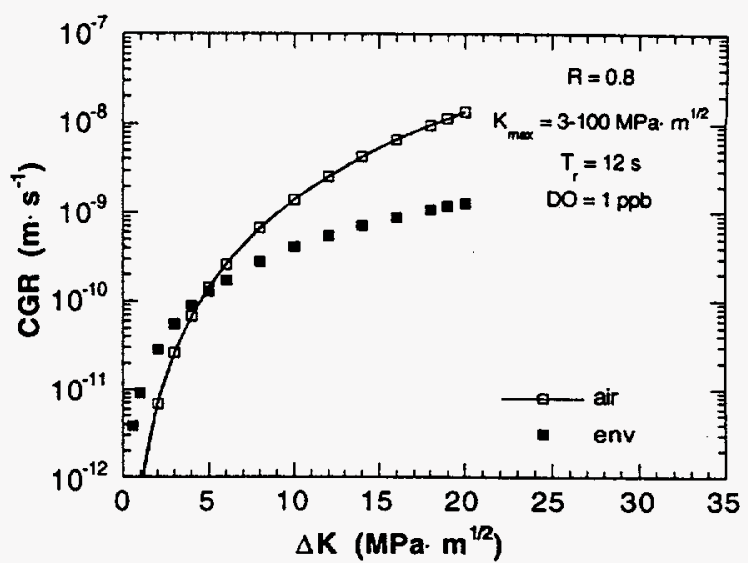

(b)

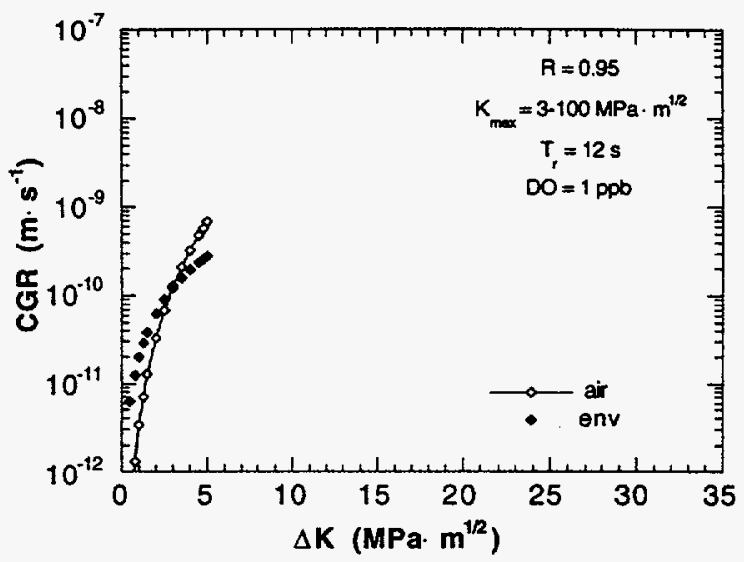

(d)

Figure 28. Contribution of air and deoxygenated-water terms in model to crack growth rate at $288^{\circ} \mathrm{C}$ vs. $\Delta \mathrm{K}$ at load ratios of (a) 0.2 , (b) 0.8 , (c) 0.9 , and (d) 0.95

$600\left(\approx 232\right.$ vs. $327 \mathrm{MPa}$ at $\left.320^{\circ} \mathrm{C}\right)$. Because mechanically driven crack growth can be correlated with yield stress, this could be simply a heat-to-heat variation. The data at several load ratios also suggest that there is a threshold $\Delta K$ at which rates increase significantly with a minimal increase in $\Delta \mathrm{K}$, and then increase more slowly as $\Delta \mathrm{K}$ increases in a manner consistent with model predictions. At load ratios $\leq 0.8$, it appears that CGRs of the Alloy 690 specimens are slightly higher than those of Alloy 600; however, at an R of 0.9 the rates for both alloys are similar. Threshold $\Delta \mathrm{Ks}$ are indicated in Figs. 27 and 28 and the values are

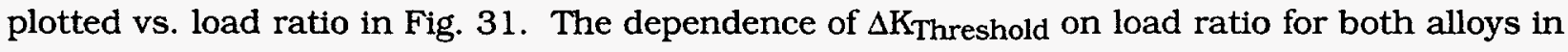
deoxygeriated water at 289 and $320^{\circ} \mathrm{C}$ is given by the equation

$$
\Delta \mathrm{K}_{\mathrm{th}}=32.0(1-\mathrm{R}) .
$$

Crack growth experiments will be conducted on specimens from other heats of the alloys at high load ratios, including constant load $(R=1.0)$, to determine the effect of yield stress on the rates, and whether Alloy 690 exhibits lower rates than Alloy 600 at higher $R$ values. 


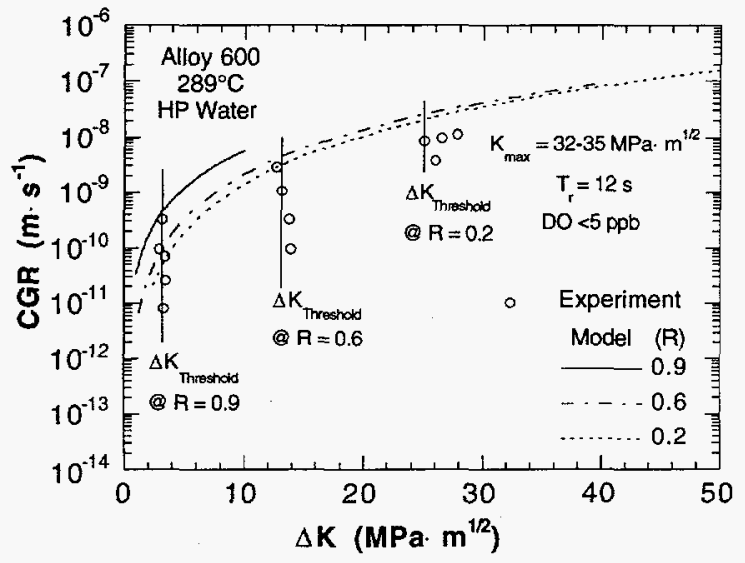

(a)

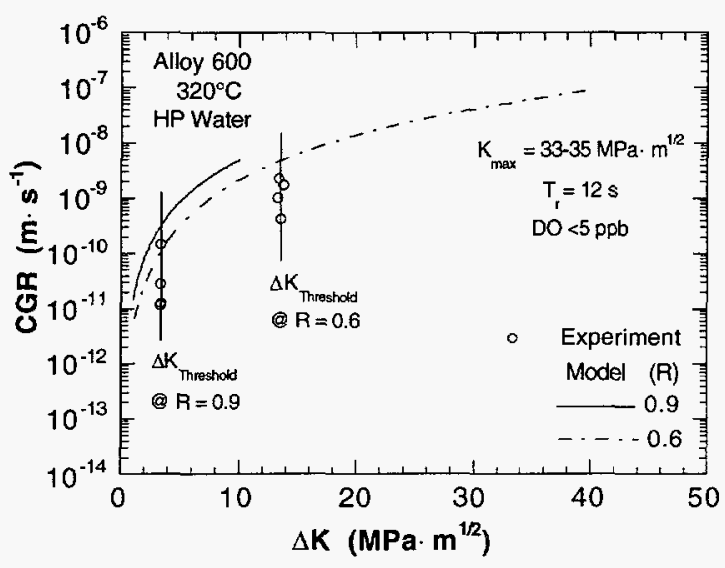

(c)

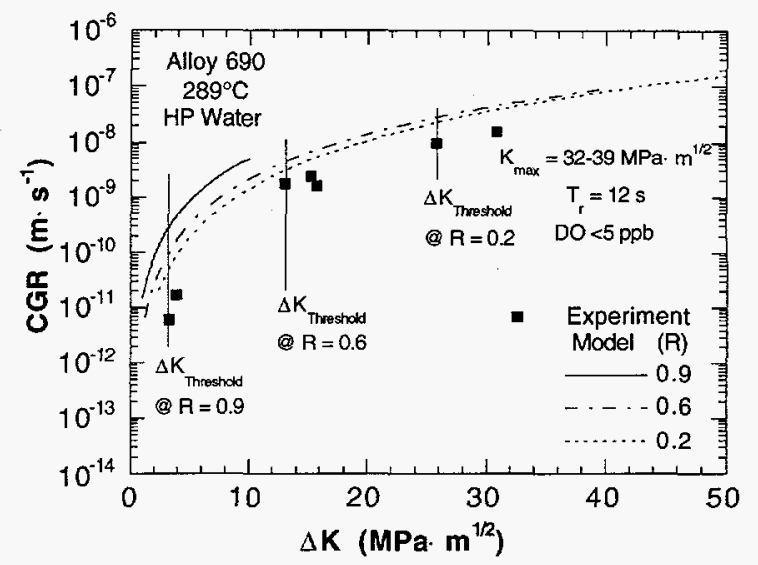

(b)

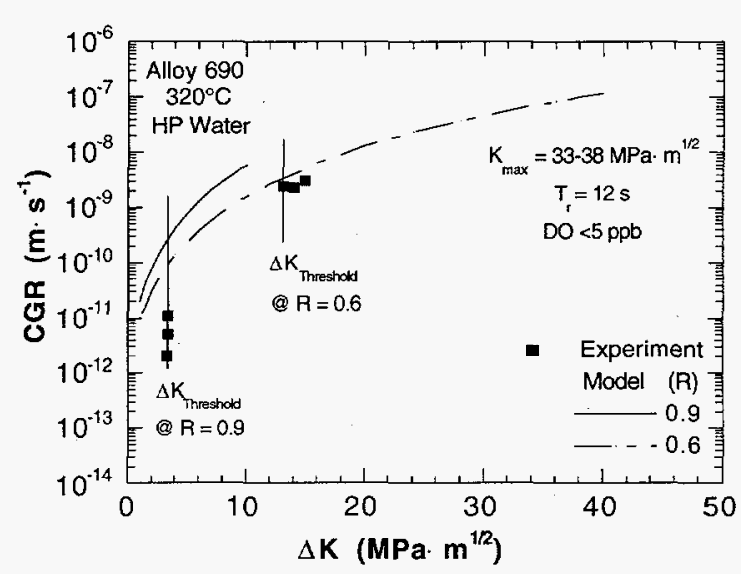

(d)

Figure 29. Dependence of CGRs of Alloy 600 and 690 specimens in deoxygenated HP water on $\Delta K$ at (a) and (b) 289 , and (c) and (d) $320^{\circ} \mathrm{C}$

\subsection{Morphology of Crack Path and Surface of Alloy 600 and 690 Specimens}

Morphology of corrosion-fatigue cracks in the Alloy 600 and 690 specimens listed in Tables 6-9 has been determined. The 1TCT specimens were sectioned vertically, and one-half of each specimen was split in the plane of the crack in liquid nitrogen. Corrosion-product films were removed from the fracture surface by a chemical process to reveal the morphology of the underlying material. The intact portion of the specimen that encompassed the crack was polished and etched to corroborate the mode of crack propagation and also to determine if crack branching had occurred during the test. The total crack lengths at the end of the test were consistent with values obtained by DC potential-drop and compliance techniques.

Figures 32-37 show the fracture surface, fracture morphology, and crack path in the crack-tip region of the specimens. The Alloy 600 specimen (Table 6 ), which has a very small grain size, exhibited intergranular cracking in oxygenated water (Fig. 32). The crack path in the Alloy 600 specimen in which the environment at the beginning and end of the experiment was simulated primary PWR, with an intermediate period of oxygenated HP water (Table 7), revealed transgranular cracking under all conditions (Fig. 33). The Type 316NG and 


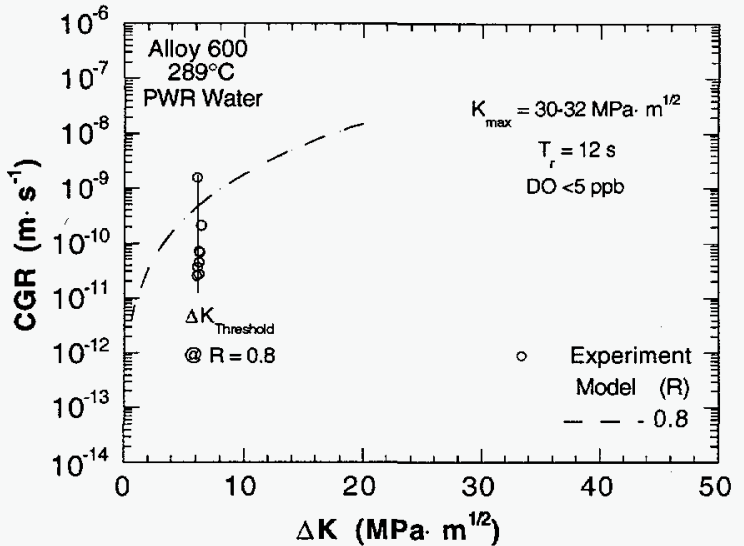

(a)

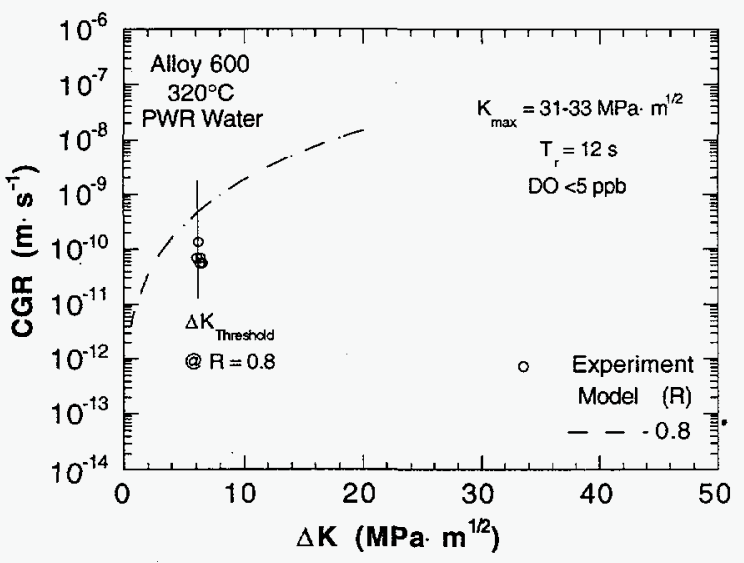

(c)

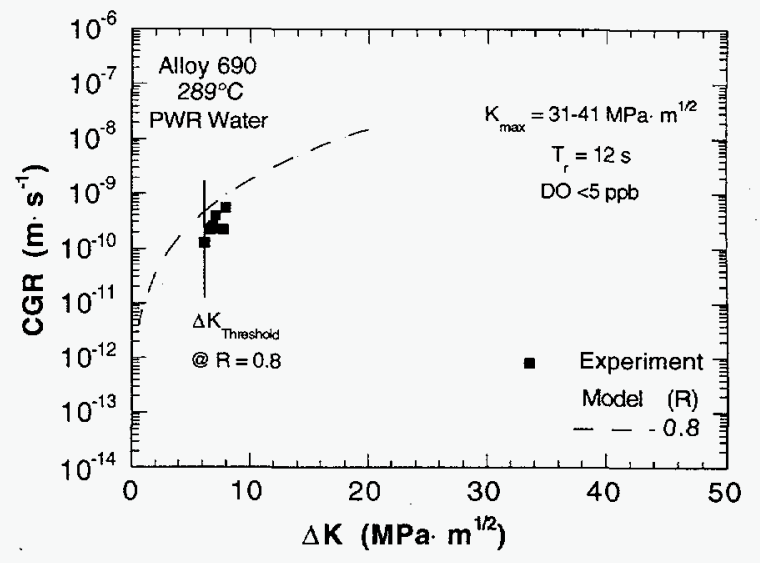

(b)

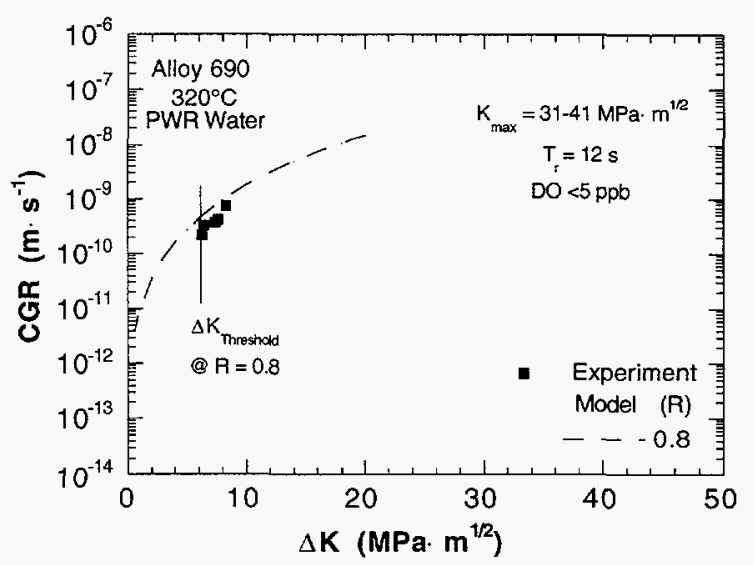

(d)

Figure 30. Dependence of CGRs of Alloy 600 and 690 specimens in simulated PWR water on $\Delta K$ at (a) and (b) 289 , and (c) and (d) $320^{\circ} \mathrm{C}$

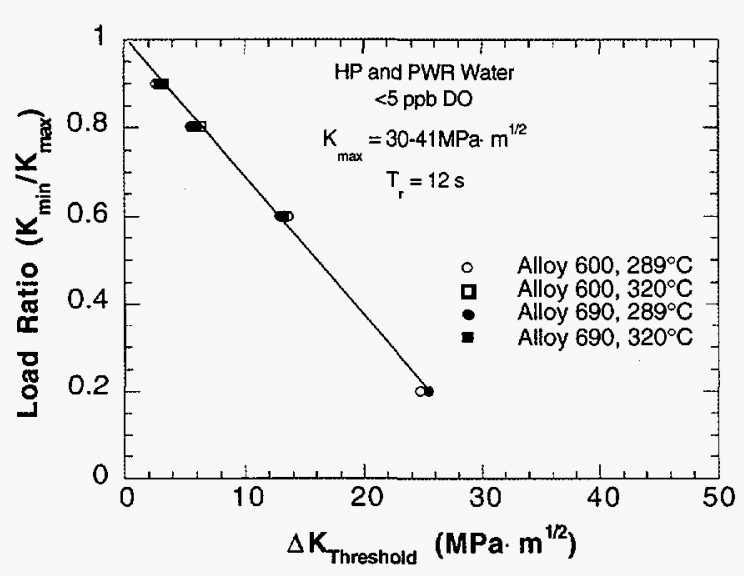

Figure 31.

Dependence of $\Delta K_{\text {th }}$ for Alloy 600 and 690 specimens in simulated PWR and deoxygenated HP water on load ratio at 289 and $320^{\circ} \mathrm{C}$

sensitized Type 304 SS specimens also exhibited a transgranular mode of crack propagation during tests in simulated PWR water and in oxygenated HP water. ${ }^{6}$ Intergranular cracking of the sensitized Type 304 SS specimen in oxygenated water was not observed because of the low load ratio in most of the tests. 


\begin{tabular}{|l|c|c|c|}
\hline ALLOY 600 & HEAT TREATMENT & LOAD CONDITIONS & ENVIRONMENT \\
Spec. No. IN-1 & Mill annealed & $\mathrm{K}_{\max }=28-36 \mathrm{MPm}^{1 / 2}$ & $200-300$ ppb Do \\
Heat No. J422 & & $R=0.60-0.95$ & $0-200$ ppb Chromate \\
& & Freq. $=0.077 \mathrm{~Hz}$ & $0-100$ ppb Sulfate \\
\hline
\end{tabular}

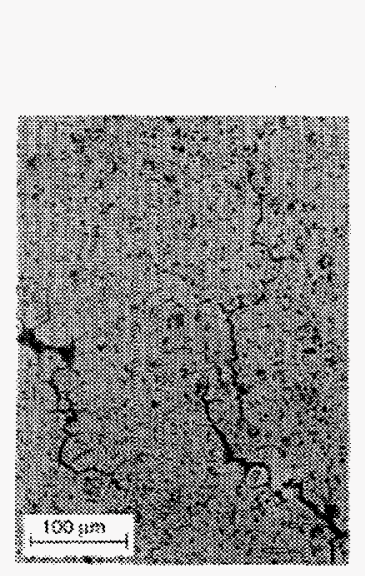

CRACK TP REGION

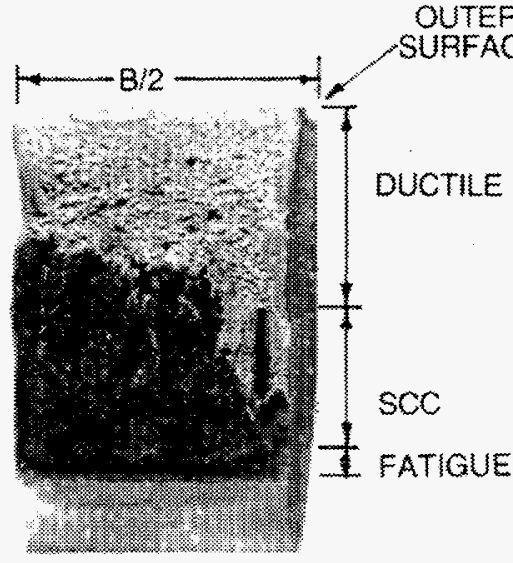

FRACTURE SURFACE
OUTER

0-100 ppb Sulfate

Figure 32. Crack path, fracture surface, and fracture morphology of 1TCT specimen of Alloy 600 (No. IN-1) after crack growth experiment in oxygenated HP water and oxygenated water containing chromate, sulfate, 2-butanone-oxime, or ethanolamine at $289^{\circ} \mathrm{C}$

\begin{tabular}{|l|c|c|c|}
\hline ALLOY 600 & HEAT TREATMENT & LOAD CONDITIONS & $\begin{array}{c}\text { ENVIRONMENT } \\
\text { HP Water: } 6 \mathrm{ppm} \text { DO and } \\
\text { Spec. No. IN-2 }\end{array}$ \\
Heat No. J422 & Mill annealed & $\mathrm{K}_{\max }=29-31 \mathrm{MPm}$ & $1 / 2$ \\
& & PWR: $450 \mathrm{ppm} \mathrm{B}, 2.25 \mathrm{ppm}$ L \\
& & Freq. $=0.077 \mathrm{~Hz}$ at $\mathrm{R}<1 . \phi$ & $4-45 \mathrm{~cm}^{3} \mathrm{H}_{2} \mathrm{~kg}^{-1} \mathrm{H}_{2} \mathrm{O}$ \\
\hline
\end{tabular}

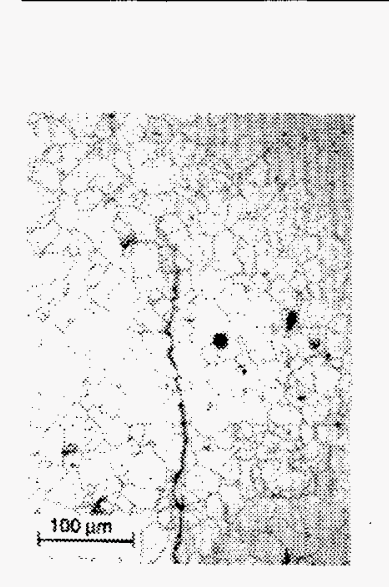

CRACK TIP REGION

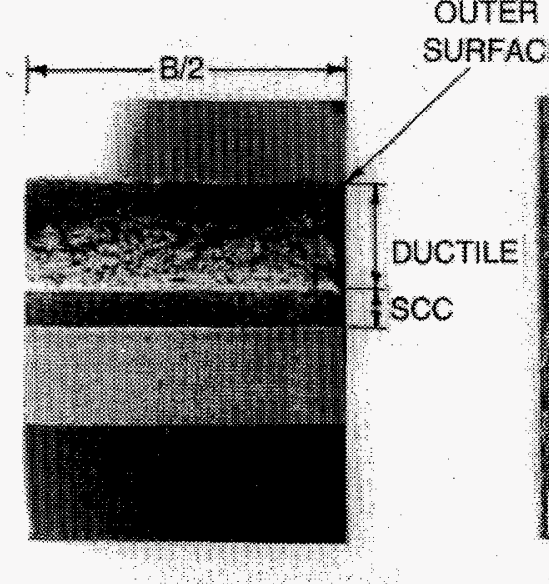

FRACTURE SURFACE

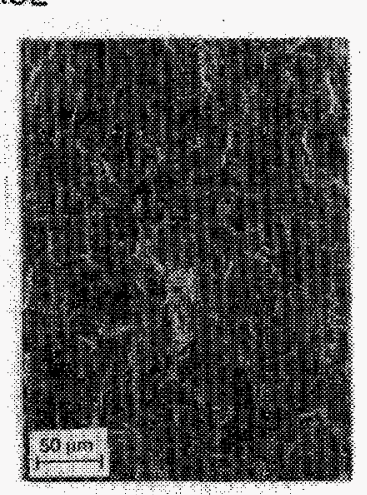

FRACTURE MORPHOLOGY

Figure 33. Crack path, fracture surface, and fracture morphology of 1 TCT specimen of Alloy 600 (No. IN-2) after crack growth experiment in HP water and simulated PWR water at $289^{\circ} \mathrm{C}$ 


\begin{tabular}{|c|c|c|c|}
\hline ALLOY 600 & HEAT TREATMENT & LOAD CONDITIONS & ENVIRONMENT \\
Spec. No. 197-07 & Mill annealed & $\mathrm{K}_{\max }=31-35 \mathrm{MPm}^{1 / 2}$ & $<0.005-7.5 \mathrm{ppm}$ DO \\
Heat No. NX8197 & & $\mathrm{R}=0.2-1.0$ & $0-53 \mathrm{~cm}^{3} \mathrm{H}_{2} \cdot \mathrm{kg}^{-1} \mathrm{H}_{2}$ \\
& & Freq. $=0.077 \mathrm{~Hz}, \mathrm{R}<1.0$ & $0.06-0.09 \mathrm{~s} \cdot \mathrm{cm}^{-1}$ \\
\hline
\end{tabular}

OUTER SURFACE

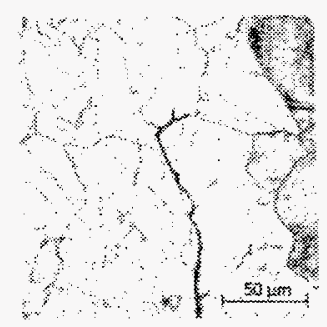

CFACK TIP REGION

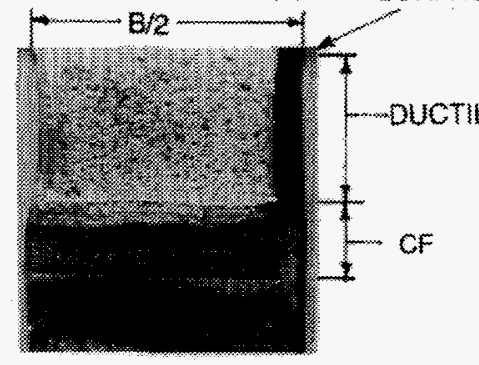

FRACTURE SURFACE

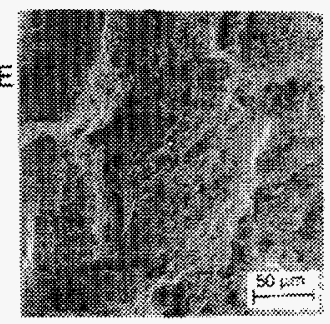

FRACTURE MORPHOLOGY

Figure 34. Crack path, fracture surface, and fracture morphology of 1TCT specimen of Alloy 600 (No. 197-07) after crack growth experiment in $\mathrm{HP}$ water at 289 and $320^{\circ} \mathrm{C}$

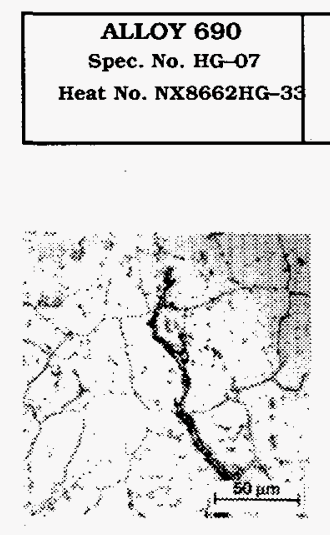

CRACK TIP REGION

\begin{tabular}{|c|c|c|}
\hline HEAT & LOAD CONDITIONS & ENVIRONMENT \\
TREATMENT & $\mathrm{K}_{\operatorname{maz}}=31-39 \mathrm{MPm}{ }^{1 / 2}$ & $<0.005-7.5 \mathrm{ppm}$ Do \\
Mill annealed plus & $\mathbf{R}=0.2-1.0$ & $0-53 \mathrm{cn}^{3} \mathrm{H}_{2} \cdot \mathrm{kg}^{-1} \mathrm{H}_{2} \mathrm{O}$ \\
$715^{\circ} \mathrm{C}$ for $5 \mathrm{~h}$ & Freq. $=0.077 \mathrm{~Hz}, \mathrm{R}<1.0$ & $0.06-0.09 \mathrm{~s} \cdot \mathrm{cm}^{-1}$ \\
\hline
\end{tabular}

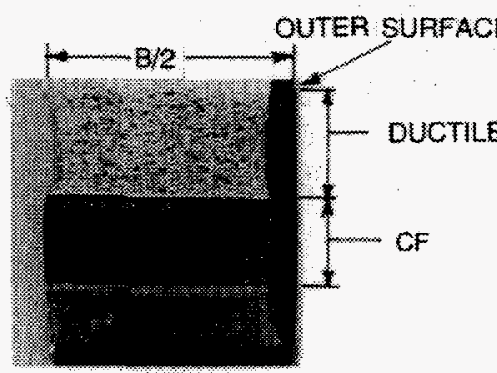

FRACTURE SUFFACE

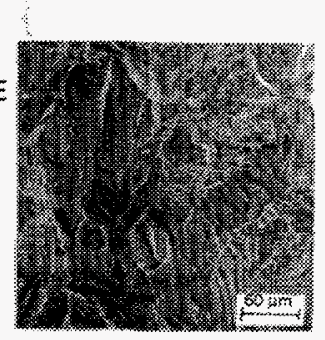

FPACTURE MOPPHOLOOY

Figure 35. Crack path, fracture surface, and fracture morphology of 1TCT specimen of Alloy 690 (No. HG-07) after crack growth experiment in $\mathrm{HP}$ water at 289 and $320^{\circ} \mathrm{C}$

\begin{tabular}{|c|c|c|c|}
\hline ALLOY 600 & HEAT TREATMENT & LOAD CONDITIONS & ENVIRONMENT \\
Spec. No. 197-09 & Mill annealed & $K_{\max }=30-33 \mathrm{MPm}^{1 / 2}$ & PWR; $<2 \mathrm{ppb}$ DO \\
Heat No. NX8197 & & $\mathrm{R}=0.8$ & $2-58 \mathrm{~cm}^{3} \mathrm{H}_{2} \cdot \mathrm{kg}^{-1} \mathrm{HO}$ \\
& & Freq. $=0.077 \mathrm{~Hz}$ & $450 \mathrm{ppm} \mathrm{B,} 2.25 \mathrm{ppm} \mathrm{Li}$ \\
\hline
\end{tabular}

OUTEP SURFACE

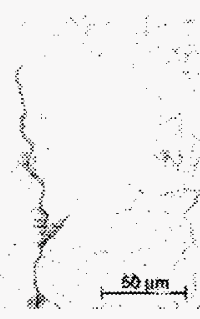

CRACK TIP REGION

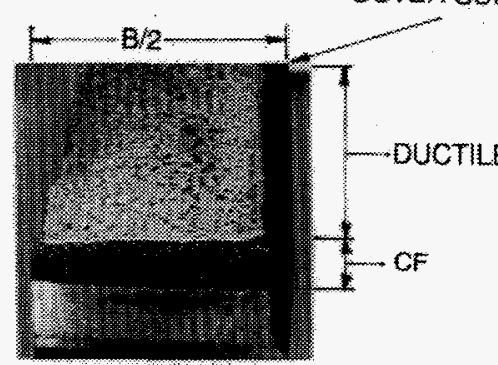

FPACTURE SUAFACE

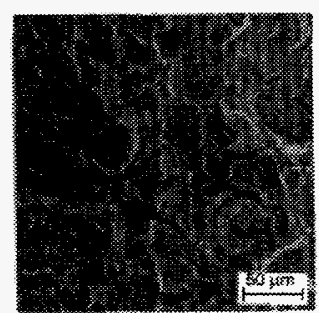

FRACTURE MORPHOLOGY

Figure 36. Crack path, fracture surface, and fracture morphology of 1TCT specimen of Alloy 600 (No. 197-09) after crack growth experiment in simulated PWR water at 289 and $320^{\circ} \mathrm{C}$ 


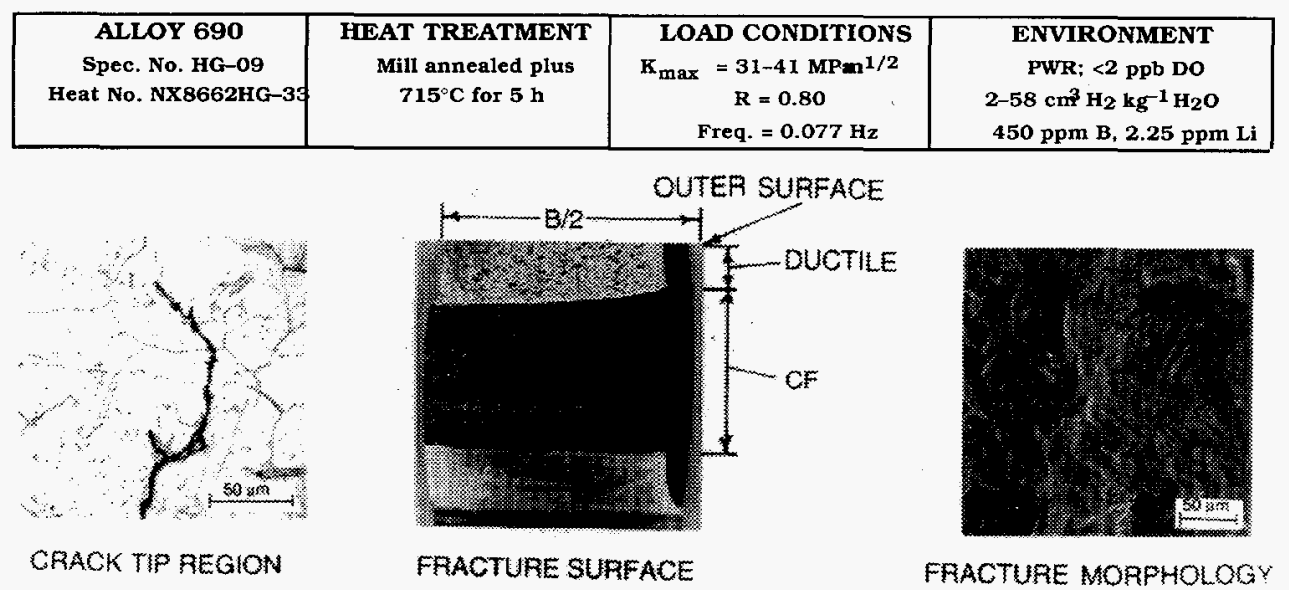

Figure 37. Crack path, fracture surface, and fracture morphology of 1TCT specimen of Alloy 690 (No. HG-09) after crack growth experiment in simulated PWR water at 289 and $320^{\circ} \mathrm{C}$

The Alloy 600 and 690 specimens from the CGR experiments in HP water (Table 8) with a range of DO concentrations and in low-oxygen water with several concentrations of dissolved hydrogen exhibited transgranular modes of crack propagation (Figs. 34 and 35, respectively). The specimens from the CGR experiments in simulated PWR water (Table 9) also revealed predominately transgranular crack propagation (Figs. 36 and 37). The transgranular mode of crack propagation can be attributed to the strong contribution of mechanical cyclic loading in tests at a load ratio of 0.8 .

\section{Summary and Conclusions}

Fracture-mechanics CGR tests were conducted on compact-tension specimens of millannealed Alloy 600 and mill-annealed and thermally treated Alloy 690 in oxygenated water and in deoxygenated water that contained boron, lithium, and low concentrations of dissolved hydrogen at 289 and $320^{\circ} \mathrm{C}$.

Several tests were conducted on mill-annealed Alloy 600 and sensitized Type 304 SS specimens in simulated BWR water at conductivities of $\approx 0.08-8.3 \mu \mathrm{S} \cdot \mathrm{cm}^{-1}$. Small amounts of chromate and sulfate $(<200 \mathrm{ppb})$ and two amines $(1-5 \mathrm{ppm})$ in water that contained $\approx 200 \mathrm{ppb}$ DO produced small but measurable changes in the CGRs of the sensitized Type 304 SS specimens but had virtually no effect on the CGR of the mill-annealed Alloy 600 specimen at a load ratio of 0.95 . The CGRs of Alloy 600 and sensitized Type 304 SS were virtually the same under conditions where EAC occurred in both materials, i.e., when the stress intensity $K$ exceeded a threshold value at a given load ratio. The average CGR of the Alloy 600 and sensitized Type 304 SS specimens was $\approx 2.3 \times 10^{-10} \mathrm{~m} \cdot \mathrm{s}^{-1}$ at an $\mathrm{R}$ of 0.95 and $\mathrm{K}_{\max }$ of $>30 \mathrm{MPa} \cdot \mathrm{m}^{1 / 2}$ under these water chemistry conditions. This average rate is consistent with numerous determinations of EAC of sensitized Type 304 and nonsensitized Type 316NG SS specimens in oxygenated water at $289^{\circ} \mathrm{C}$ under similar loading conditions. The observation that different materials, e.g., Alloy 600, sensitized Type 304, nonsensitized Type 316NG, and $\mathrm{CF}-3, \mathrm{CF}-8$ and $\mathrm{CF}-8 \mathrm{M}$ grades of cast SSs, exhibit the same CGR in oxygenated water, despite significant differences in material chemistry, microstructure, and mode of crack propagation, suggests that crack propagation is controlled by the rate of cathodic reduction of DO with a concomitant anodic dissolution process at the crack tip. Experimental data for the three 
specimens were compared with predictions from an ANL model for CGRs of SSs in water ${ }^{5}$ and the ASME Section XI correlation for CGRs in air at the $K_{\max }$ and load ratio values in the various tests. The data for both materials were bounded by the two curves.

The crack growth behavior of Alloy 600, Type 316NG, and sensitized Type 304 SS was investigated in simulated PWR water at high load ratios, where an environmental contribution to cracking may be significant. Tests were conducted at $289^{\circ} \mathrm{C}$ in water that contained $450 \mathrm{ppm}$ boron and $2.25 \mathrm{ppm}$ lithium (added to the feedwater as $\mathrm{H}_{3} \mathrm{BO}_{3}$ and $\mathrm{LiOH}$ ), 4-45 $\mathrm{cm}^{3}$ $\mathrm{H}_{2} \cdot \mathrm{kg}^{-1} \mathrm{H}_{2} \mathrm{O}, \approx 1 \mathrm{ppb}$ DO, and $750 \mathrm{ppb}$ hydrazine. The CGR data for the specimens were compared with predictions from the ANL crack-growth model that was modified to account for a very low DO concentration in simulated PWR primary-system water. With the exception of one data point for the Alloy 600 specimen, the experimental results in water were bounded by the ANL model prediction and the "air line" for austenitic SSs from the ASME Code Section XI correlation.

Several CGR tests were performed on this set of specimens in HP water that contained $\approx 6 \mathrm{ppm}$ DO at load ratios between 0.2 and 1.0. CGRs in this environment were also compared with predictions of the ANL model for crack growth in oxygenated water and with the air line from the ASME Section XI correlation at the $K_{\max }$ and load ratio values for the specimens. Once again, the experimental data were bounded by the two curves and the ANL model provides a good upper-bound estimate of the CGRs at all load ratios.

Corrosion-fatigue experiments were conducted on mill-annealed Alloy 600 and millannealed plus thermally treated Alloy 690 specimens in HP water to investigate the effects of temperature, load ratio, DO, and dissolved hydrogen in water on CGRs. Crack growth behavior of the two materials is quite similar under the conditions in these experiments. At a load ratio of 0.6 , the CGRs are not dependent on DO, which is indicative of a strong contribution of cyclic loading to the rates. At a higher load ratio of 0.9 , the CGRs decrease as DO concentration decreases at 289 and $320^{\circ} \mathrm{C}$. In all cases, the CGRs of both materials lie near or below the air curve for austenitic SSs.

Several tests were conducted at $320^{\circ} \mathrm{C}$ in $\mathrm{HP}$ water that contained $<5 \mathrm{ppb}$ DO and $\approx 0,2.2$, and $53 \mathrm{~cm}^{3} \cdot \mathrm{kg}^{-1}$ dissolved hydrogen. At a load ratio of 0.9 , CGRs of both specimens were low $\left(0.5-1.3 \times 10^{-11} \mathrm{~m} \cdot \mathrm{s}^{-1}\right)$ and dissolved hydrogen over the range of $\approx 2-53 \mathrm{~cm}^{3} \mathrm{H}_{2} \cdot \mathrm{kg}^{-1} \mathrm{H}_{2} \mathrm{O}$ did not influence the rates at a $\mathrm{K}_{\max }$ of $\approx 34 \mathrm{MPa} \cdot \mathrm{m}^{1 / 2}$. In contrast to results at lower load ratios (i.e., $\leq 0.6$ ), CGRs of Alloy 600 were greater than those of Alloy 690 by factors of $\approx 2-5$.

The influence of dissolved hydrogen in simulated PWR water on CGRs of Alloy 600 and 690 specimens from the same heats of material was determined in another series of experiments at 289 and $320^{\circ} \mathrm{C}$. The tests were conducted at a load ratio of 0.8 and $\mathrm{K}_{\max }$ in the range $\approx 30-39 \mathrm{MPa} \cdot \mathrm{m}^{1 / 2}$. The CGRs decreased slightly as the dissolved-hydrogen concentration increased from 3 to $58 \mathrm{~cm}^{3} \cdot \mathrm{kg}^{-1}$. Under these water chemistry and loading conditions, CGRs of Alloy 690 were higher by a factor of $\approx 3$ than the CGRs of Alloy 600 at both temperatures.

The morphology of corrosion-fatigue cracks in the Alloy 600 and 690 specimens was determined. In simulated BWR water that contained $\approx 200 \mathrm{ppb} D O$, the crack path in the Alloy 600 and sensitized Type 304 SS specimens was predominantly intergranular. The crack path 
in the Alloy 600, Type $316 \mathrm{NG}$, and sensitized 304 SS specimens in which the environment at the beginning and end of the experiment was simulated PWR primary-system water but in which there was an intermediate period of oxygenated HP water, revealed transgranular cracking. Intergranular cracking of the sensitized Type 304 SS specimen in oxygenated water was not observed because of the low load ratios in most of the tests. In deoxygenated HP water and simulated PWR water, predominately transgranular cracking occurred at load ratios $<0.9$, which were used in most of the tests.

\section{Future Work}

Corrosion-fatigue tests will be performed on Alloy 600 and 690 specimens with differing heat treatments (Table 1) to assess the influence of microstructure, viz., carbide distribution and grain size, on CGRs in simulated LWR environments. Alloy 690 in the $20 \%$ cold-worked condition will also be tested. Most of the experiments will be conducted at $R>0.9$ to maximize the environmental contribution to crack growth even though CGRs decrease significantly at high load ratios. These tests will confirm whether Alloy 690 exhibits lower CGRs than Alloy 600 at high load ratios, including constant load $(\mathrm{R}=1.0)$. Because CGRs will be relatively low $\left(<5 \times 10^{-11} \mathrm{~m} \cdot \mathrm{s}^{-1}\right)$, each experiment will entail a longer test time $(\approx>800 \mathrm{~h})$ to obtain reliable measurements for incremental crack depths $\approx 150 \mu \mathrm{m}$ or several grain diameters. Experiments will be performed in air as well as in water to determine threshold stress intensity values for crack propagation at high $\mathrm{R}$ values in both environments. Tests will also be performed over a wider temperature range under conditions where EAC occurs, to quantify the true activation energy for crack propagation. These results will make possible a more quantitative assessment of the degree of environmental enhancement in water for the same material, heat treatment, and loading conditions. The influence of the concentration of dissolved hydrogen in water on crack growth will be investigated at high $\mathrm{R}$ values to determine whether there is an abrupt decrease in CGRs over a regime of temperature and hydrogen concentration where the $\mathrm{NiO}$ corrosion product is not thermodynamically stable. The results will be compared with similar crack-growth information for austenitic SSs in air from Section $\mathrm{XI}$ of the ASME Code and with values predicted by a correlation developed by ANL for EAC of these steels in high-temperature water. If necessary, the correlation will be modified to better reflect the properties of Alloys 600 and 690. 


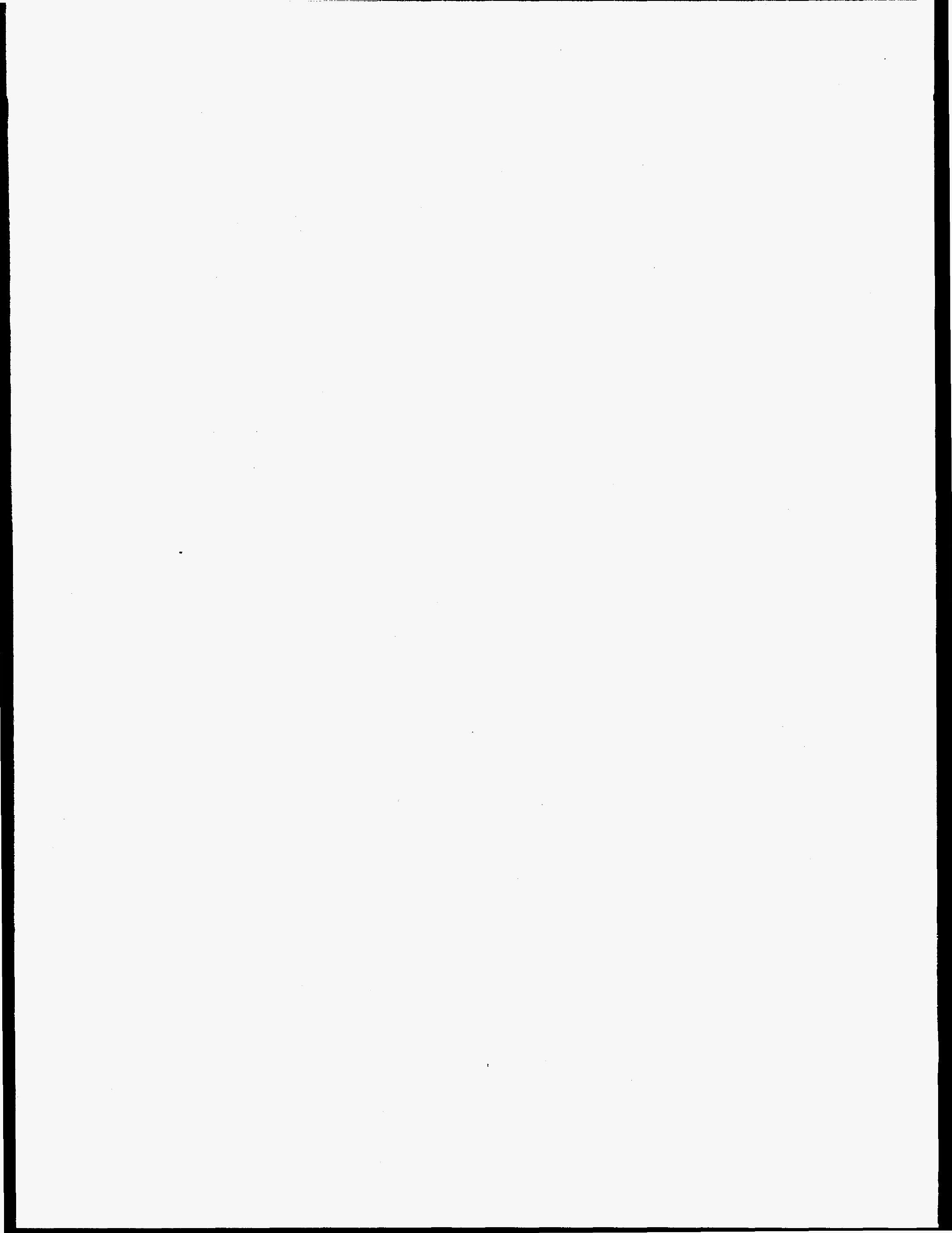




\section{References}

1. G. L. Webb and M. G. Burke, Stress Corrosion Cracking Behavior of Alloy 600 in High Temperature Water, Proc. 7th Int. Symp. Environmental Degradation of Materials in Nuclear Power Systems - Water Reactors, G. Aiery et al., eds., NACE International, Houston, TX, pp. 41-55 (1995).

2. D. A. Mertz, P. T. Duda, P. N. Pica, and G. L. Spahr, Role of Microstructure in Caustic Stress Corrosion Cracking of Alloy 690, Proc. 7th Int. Symp. Environmental Degradation of Materials in Nuclear Power Systems - Water Reactors, G. Aiery et al., eds., NACE International, Houston, TX, pp. 477-493 (1995).

3. T. M. Angeliu and G. S. Was, Grain Boundary Chemistry and Precipitation in Controlled Purity Alloy 690, Proc. 4th Int. Symp. Environmental Degradation of Materials in Nuclear Power Systems - Water Reactors, D. Cubicciotti, ed., NACE, Houston, TX, pp. 5-64 to 5-77 (1990).

4. J. M. Sarver, J. R. Crum, and W. L. Mankins, Carbide Precipitation and the Effect of Thermal Treatments on the SCC Behavior of Inconel Alloy 690, Proc. 3rd Int. Symp. Environmental Degradation of Materials in Nuclear Power Systems - Water Reactors, G. J. Theus and J. R. Weeks, eds., The Metallurgical Society, Warrendale, PA, pp. 581-586 (1988).

5. W. J. Shack and T. F. Kassner, Review of Environmental Effects on Fatigue Crack Growth of Austenitic Stainless Steels, NUREG/CR-6176, ANL-94/1, (May 1994).

6. W. E. Ruther, W. K. Soppet, and T. F. Kassner, in Environmentally Assisted Cracking in Light. Water Reactors, Semiannual Report, April-September 1994, NUREG/CR-4667 Vol. 19, ANL-95/25, pp. 20-32 (September 1995).

7. W. E. Ruther, T. F. Kassner, and J. Y. Park, in Environmentally Assisted Cracking in Light Water Reactors, Semiannual Report, October 1991-March 1992, NUREG/CR-4667 Vol. 14, ANL-92/30, pp. 33-45 (Aug. 1992).

8. W. E. Ruther and T. F. Kassner, in Environmentally Assisted Cracking in Light Water Reactors, Semiannual Report, April-September 1993, NUREG/CR-4667 Vol. 17, ANL-94/16, pp. 22-34 (June 1994).

9. W-K. Lai and Z. Szklarska-Smialowska, Effect of Heat Treatment on the Behavior of Alloy 600 in Lithiated Water Containing Dissolved Hydrogen at 25 and $350^{\circ} \mathrm{C}$, Corrosion 47, 40-47 (1991).

10. R. B. Rebak and Z. Szklarska-Smialowska, Effect of Partial Pressure of Hydrogen on IGSCC of Alloy 600 in PWR Primary Water, Corrosion 47, 754-757 (1991).

11. T. F. Kassner, W. E. Ruther, and W. K. Soppet, Mitigation of Stress Corrosion Cracking of AISI 304 Stainless Steel by Organic Species at Low Concentration in Oxygentaed Water at $289^{\circ} \mathrm{C}$, Corrosion 90, Paper 489, National Association of Corrosion Engineers, April 23-27, 1990, Las Vegas, NV.

12. W. E. Ruther, W. K. Soppet, and T. F. Kassner, in Light-Water-Reactors Safety Materials Engineering Research Programs:, Quarterly Progress Report, January-March 1985, NUREG/CR-4490 Vol. 1, ANL-85-75 Vol. 1, pp. 25-42 (March 1986). 
13. L. A. James and D. P. Jones, Fatigue Crack Growth Correlation for Austenitic Stainless Steels in Air, Proc. Conf. on Predictive Capabilities in Environmentally-Assisted Cracking, R. Rungta, ed., PVP Vol. 99, American Society of Mechanical Engineers, NY, pp. 363-414 (1985).

14. T. Shoji, H. Takahashi, M. Suzuki, and T. Kondo, A New Parameter for Characterizing Corrosion Fatigue Crack Growth, J. Eng. Mater. Technol. 103, 298-304 (1981).

15. J. D. Gilman, R. Rungta, P. Hinds, and H. Mindlan, Corrosion-Fatigue Crack Growth Rates in Austenitic Stainless Steels in Light Water Reactor Environments, Int. J. Pressure Vessel Piping 31, 55-68 (1988). 


\section{Distribution for NUREG/CR-6383 (ANL-95/37)}

Internal

T. F. Kassner (45)

TIS Files

External

NRC, for distribution per R5

Libraries

ANL-E (2)

ANL-W

Manager, Chicago Field Office, DOE

Energy Technology Division Review Committee:

H. K. Birnbaum, University of Illinois, Urbana

R. C. Buchanan, University of Cincinnati, Cincinnati, $\mathrm{OH}$

S. N. Liu, Fremont, CA

H. S. Rosenbaum, Fremont, CA

R. K. Shah, University of Kentucky, Lexington

S. Smialowska, Ohio State University, Columbus

R. E. Smith, Altran Corporation, Huntersville, NC

P. L. Andresen, General Electric Corporate Research and Development, Schenectady, NY

T. A. Auten, Knolls Atomic Power Laboratory

R. G. Ballinger, Massachusetts Institute of Technology, Cambridge, MA

W. H. Bamford, Westinghouse Electric Corp., Pittsburgh

J. M. Boursier, Electricite de France-Generating and Transmission Group Central Laboratories, Avoine, France

A. Brennenstuhl, Ontario Hydro, Toronto, Ontario, Canada

S. M. Bruemmer, Battelle Pacific Northwest Laboratory

H. S. Chung, Korea Atomic Energy Research Institute, Daejeon, Korea

L. Coressti, ABB CE Nuclear Power, Windsor, CT

R. L. Cowan, General Electric Co., San Jose, CA

G. Cragnolino, Southwest Research Inst., San Antonio, TX

W. H. Cullen, Materials Engineering Assoc., Inc., Lanham, MD

E. D. Eason, Modeling and Computing Services, Newark, CA

J. Fish, Knolls Atomic Power Laboratory

J. P. Foster, Westinghouse Electric Corp., Pittsburgh

M. Fox, Tucson, AZ

D. G. Franklin, Bettis Atomic Power Laboratory

Y. S. Garud, S. Levy, Inc., Campbell, CA

F. Garzarolli, KWU, Erlangen, Germany

J. Gilman, Electric Power Research Inst., Palo Alto, CA

B. M. Gordon, General Electric Co., San Jose, CA

K. Gott, Swedish Nuclear Power Inspectorate, Stockholm, Sweden 
M. M. Hall, Bettis Atomic Power Laboratory

J. W. Halley, U. Minnesota, Minneapolis

H. E. Hanninen, Technical Research Centre of Finland, Espoo

D. Harrison, USDOE, Germantown, MD

J. Hickling, CML Capcis March Ltd., Erlangen-Tennonlohe, Germany

M. Higuchi, Ishikawajima-Harima Heavy Industries Co., Ltd., Japan

C. Hoffmann, ABB CE Nuclear Power, Windsor, CT

H. S. Isaacs, Brookhaven National Laboratory

A. Jacobs, General Electric Co., San Jose, CA

L. James, Bettis Atomic Power Laboratory

C. Jansson, Vattenfall Energisystem, Vallingby, Sweden

D. P. Jones, Bettis Atomic Power Laboratory

R. H. Jones, Battelle Pacific Northwest Laboratory

R. L. Jones, Electric Power Research Institute, Palo Alto, CA

T. Karlsen, OECD Halden Reactor Project, Halden, Norway

C. Kim, Westinghouse Electric Corp., Pittsburgh

L. Ljungberg, ABB-ATOM AB, Vasteras, Sweden

D. D. Macdonald, Pennsylvania State University, University Park

T. R. Mager, Westinghouse Electric Corp., Pittsburgh

R. D. McCright, Lawrence Livermore National Laboratory

A. R. McIlree, Electric Power Research Institute, Palo Alto, CA

H. Metha, General Electric Co., San Jose, CA

D. Morgan, Pennsylvania Power and Light Co., Allentown, PA

J. L. Nelson, Electric Power Research Inst., Palo Alto, CA

M. Pytel, Structural Integrity Associates, San Jose, CA

M. Prager, Materials Properties Council, New York, NY

S. Ranganath, General Electric Co., San Jose, CA

P. M. Scott, Framatome, Paris, France

A. J. Sedriks, Office of Naval Research, Arlington, VA

C. Shepherd, AEA Technology-Harwell Labs., Didcot, Oxon, UK

H. D. Solomon, General Electric Corporate Research and Development, Schenectady, NY

M. O. Speidel, Swiss Federal Institute of Technology, Zurich, Switzerland

D. M. Stevens, Lynchburg Research Center, Babcock \& Wilcox Co., Lynchburg, VA

P. Tipping, Swiss Federal Nuclear Safety Inspectorate, Villigen, Switzerland

W. A. Van Der Sluys, Research \& Development Division, Babcock \& Wilcox Co., Alliance, $\mathrm{OH}$

J. C. Van Duysen, Electricite de France-Research and Development Centre de Renardieres, Moret-sur-Loing, France

C. Vitanza, OECD Halden Reactor Project, Halden, Norway

G. S. Was, University of Michigan, Ann Arbor

S. Yukawa, Boulder, CO 


\begin{tabular}{|c|c|}
\hline $\begin{array}{l}\text { U.S. NUCLEAR REGULATORY COMMISSION } \\
\text { BIBLIOGRAPHIC DATA SHEET } \\
\text { (See instructions on the reverse) }\end{array}$ & $\begin{array}{l}\text { 1. REPORT NUMBER } \\
\text { (Assigned by NRC. Add Vol., Supp., Rev., } \\
\text { and Addendum Numbers, if any.) } \\
\text { NUREG/CR-6383 } \\
\text { ANL-95/37 }\end{array}$ \\
\hline \multirow[t]{4}{*}{$\begin{array}{l}\text { 2. TITLE AND SUBTITLE } \\
\text { Corrosion Fatigue of Alloys } 600 \text { and } 690 \text { in Simulated LWR Environments }\end{array}$} & \\
\hline & 3. DATE REPORT PUBLISHED \\
\hline & \begin{tabular}{l|r} 
MONTH & YEAR \\
April & 1996 \\
\end{tabular} \\
\hline & $\begin{array}{l}\text { 4. FIN OR GRANT NUMBER } \\
\text { A2212 }\end{array}$ \\
\hline \multirow{3}{*}{$\begin{array}{l}\text { 5. AUTHOR(S) } \\
\text { W. E. Ruther, W. K. Soppet, and T. F. Kassner }\end{array}$} & 6. TYPE OF REPORT \\
\hline & Technical \\
\hline & 7. PERIOD COVERED (inclusive Dates) \\
\hline
\end{tabular}

name and mailing address.)

Argonne National Laboratory

9700 South Cass Avenue

Argonne, IL 60439

9. SPONSORING ORGANIZATION - NAME AND ADDRESS (If NRC, type "Same as above": if contractor, provide NRC Division, Office or Region, U.S. Nuclear Regulatory Commission,

and mailing address.)

Division of Engineering Technology

Office of Nuclear Regulatory Research

U. S. Nuclear Regulatory Commission

Washington, DC 20555-0001

10. SUPPLEMENTARY NOTES

\section{McNeil, NRC Project Manager}

\section{ABSTRACT (200 words or less)}

Crack growth data were obtained on fracture-mechanics specimens of Alloy 600 and 690 to investigate environmentally assisted cracking (EAC) in simulated boiling water reactor and pressurized water reactor environments at 289 and $320^{\circ} \mathrm{C}$. Preliminary information was obtained on the effect of temperature, load ratio, stress intensity $\mathrm{K}$, and dissolved-oxygen and -hydrogen concentrations of the water on EAC. Specimens of Type 316NG and sensitized Type 304 stainless steel (SS) were included in several of the experiments to assess the behavior of these materials and Alloy 600 under the same water chemistry and loading conditions. The experimental data are compared with predictions from an Argonne National Laboratory (ANL) model for crack growth rates (CGRs) of SSs in water and the ASME Code Section XI correlation for CGRs in air at the $\mathrm{K}_{\text {max }}$ and load-ratio values in the various tests. The data for all of the materials were bounded by ANL model predictions and the ASME Section XI "air line."

*

12. KEY WORDS/DESCRIPTORS (List words or phrases that will assist researchers in locating this report.)

Corrosion Fatigue

Crack Growth

Alloy 600

Alloy 690

Types $316 \mathrm{NG}$ and 304 Stainless Steel

LWR Environments

\begin{tabular}{|c|}
\hline $\begin{array}{l}\text { 13. AVAILABILITY STATEMENT } \\
\text { Unlimited }\end{array}$ \\
\hline 14. SECURITY CLASSIFICATION \\
\hline (This Page) \\
\hline Unclassified \\
\hline (This Report) \\
\hline Unclassified \\
\hline 15. NUMBER OF PAGES \\
\hline 16. PRICE \\
\hline
\end{tabular}




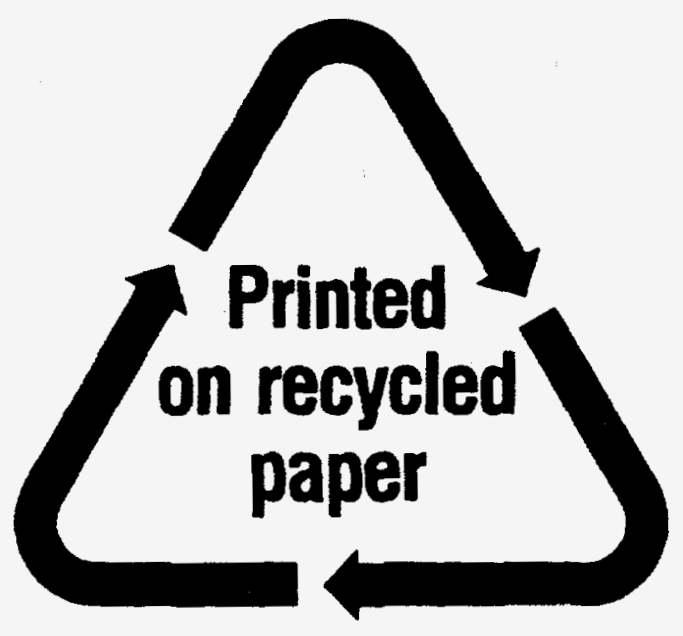

Federal Recycling Program 